


\section{Kan een goede boer natuurinclusief zijn?}

De rol van culturele normen in een beweging richting natuurinclusieve landbouw

J. Westerink, T.A. de Boer, M. Pleijte \& R.A.M. Schrijver

Project WOT-04-010-037.07

WOT Natuur \& Milieu, Wageningen University \& Research

Wageningen, december 2019

WOt-technical report 161

ISSN 2352-2739

DOI $10.18174 / 508108$ 


\section{Referaat}

Westerink, J., T.A. de Boer, M. Pleijte \& R.A.M. Schrijver (2019). Kan een goede boer natuurinclusief zijn?; De rol van culturele normen in een beweging richting natuurinclusieve landbouw. Wettelijke Onderzoekstaken Natuur \& Milieu, WOt-technical report 161. 86 blz.; 5 fig.; 2 tab.; 54 ref; 1 Bijlage.

Wat boeren zien als een goede boer en een goed landschap heeft invloed op hun houding ten opzichte van natuurinclusieve landbouw. Wij onderzochten culturele normen ten aanzien van 'goede boer' en 'goed landschap' door kwalitatief onderzoek onder 24 boeren in 4 casestudygebieden. Een goede boer is herkenbaar aan zijn land. Hoe goed land eruit hoort te zien, hangt af van het doel. Voor voedselproductie moet het strak en netjes zijn, natuurinclusief land mag er rommeliger uitzien. Respondenten zien dat culturele normen veranderen, met name als gevolg van nieuwe praktijken die zichtbaar zijn in het landschap. Voor natuurinclusieve landbouw is nieuw vakmanschap nodig om het in de praktijk te kunnen brengen en om het te kunnen herkennen en waarderen bij anderen. Dat vraagt om subculturen waarin dergelijk cultureel kapitaal wordt opgebouwd. De agrarische collectieven voor agrarisch natuurbeheer zijn daar een voorbeeld van. Het rapport bevat handelingsperspectieven voor de beïnvloeding van culturele normen.

Trefwoorden: cultureel kapitaal, vakmanschap, leren, collectief, subculturen, Midden-Limburg, Noord-Beveland, Achterhoek, Noordelijke Friese Wouden

\section{Abstract}

Westerink, J., T.A. de Boer, M. Pleijte \& R.A.M. Schrijver (2019). Can a good farmer be nature inclusive? The role of cultural norms in a shift towards nature-inclusive farming. Statutory Research Tasks Unit for Nature \& the Environment, WOt Technical Report 161. 86 p.; 5 figs; 5 tabs; 96 refs; 1 Appendix.

What farmers consider as a good farmer and a good landscape influences their views about nature inclusive farming. We investigated the cultural norms concerning the 'good farmer' and the 'good landscape' in a qualitative study involving 24 farmers in 4 case study areas. A good farmer can be recognised by his/her land, and what good land should look like depends on its use: for food production it should be tidy and well maintained; nature-inclusive land may look a bit 'messy'. Respondents notice that cultural norms are changing, particularly as a consequence of new practices that are visible in the landscape. New skills are required to put nature-inclusive farming into practice and to recognise and appreciate it in other farmers' land. This in turn requires subcultures in which such cultural capital can be accumulated. An example of such subcultures are agri-environmental collectives. The report contains action strategies for influencing cultural norms.

Keywords: cultural capital, occupational skills, learning, cooperative, subcultures, Midden-Limburg, Noord-Beveland, Achterhoek, Noordelijke Friese Wouden

Foto omslag: Bendiks Westerink

Foto's: Marcel Pleijte, Bendiks Westerink, Judith Westerink, Shutterstock

\section{(C) 2019 Wageningen Environmental Research} Postbus 47, 6700 AA Wageningen Tel: +31317480 700; e-mail: judith.westerink@wur.nl

\section{Wageningen Economic Research Postbus 29703, 2502 LS Den Haag Tel: +317033583 30; e-mail: communications.ssg@wur.nl}

Wettelijke Onderzoekstaken Natuur \& Milieu (unit binnen de rechtspersoon Stichting Wageningen Research), Postbus 47, 6700 AA Wageningen, T 03174854 71, info.wnm@wur. nl, www.wur.nl/wotnatuurenmilieu. WOT Natuur \& Milieu is onderdeel van Wageningen University \& Research. Dit rapport is gratis te downloaden van https://doi.org/10.18174/ 508108 of op www.wur.nl/wotnatuurenmilieu. De WOT Natuur \& Milieu verstrekt geen gedrukte exemplaren van rapporten.

- Overname, verveelvoudiging of openbaarmaking van deze uitgave is toegestaan mits met duidelijke bronvermelding.

- Overname, verveelvoudiging of openbaarmaking is niet toegestaan voor commerciële doeleinden en/of geldelijk gewin.

- Overname, verveelvoudiging of openbaarmaking is niet toegestaan voor die gedeelten van deze uitgave waarvan duidelijk is dat de auteursrechten liggen bij derden en/of zijn voorbehouden.

Wettelijke Onderzoekstaken Natuur \& Milieu aanvaardt geen aansprakelijkheid voor eventuele schade voortvloeiend uit het gebruik van de resultaten van dit onderzoek of de toepassing van de adviezen 


\section{Woord vooraf}

Om de beweging naar een toekomstbestendige, duurzame en sterke landbouw te faciliteren, zet het huidige kabinet in op het realiseren van een omschakeling naar kringlooplandbouw. De kern van deze vorm van landbouw is produceren met zo min mogelijk verlies aan grondstoffen en een zorgvuldig beheer van bodem, water en natuur. Natuurinclusieve landbouw- oftewel landbouw die negatieve effecten van landbouw op natuur vermindert en dit combineert met het benutten van natuur binnen de bedrijfsvoering en zorg voor natuur - kan een belangrijke rol spelen in de beweging naar kringlooplandbouw.

Om inzicht te krijgen in mogelijkheden om natuurinclusieve landbouw onder boeren te stimuleren, is het van belang om zo goed mogelijk te begrijpen hoe boeren hun keuzes maken om meer aan natuurinclusieve landbouw te gaan doen. Welke factoren zorgen ervoor dat boeren wel of juist niet bereid zijn om natuurinclusief te werken? En hoe kunnen beleidsmakers rekening houden met deze factoren en ze met beleid en beleidsinstrumenten beïnvloeden? Hier zijn al veel onderzoeken over verschenen.

Dit rapport voegt daar de culturele invalshoek aan toe. Het verkent of en hoe natuurinclusieve landbouw past bij het beeld van 'een goede boer' en 'een goed landschap' zoals dat leeft in boerengemeenschappen. Deze culturele kant van het verhaal is in onderzoeken naar ontwikkelingen in de Nederlandse landbouw tot nog toe onderbelicht gebleven. Dit rapport vormt dan ook een belangrijke aanvulling op bestaand onderzoek naar andere (o.a. ecologische en bedrijfseconomische) factoren die de houding van boeren ten opzichte van natuurinclusieve landbouw beïnvloeden.

Het rapport laat zien dat culturele normen een belangrijke rol spelen in keuzes van boeren met betrekking tot hun bedrijfsvoering en dat deze culturele normen langzaam aan het veranderen zijn. Voor beleid biedt dit relevante inzichten en een aanvullend handelingsperspectief.

Michiel de Krom en Petra van Egmond 


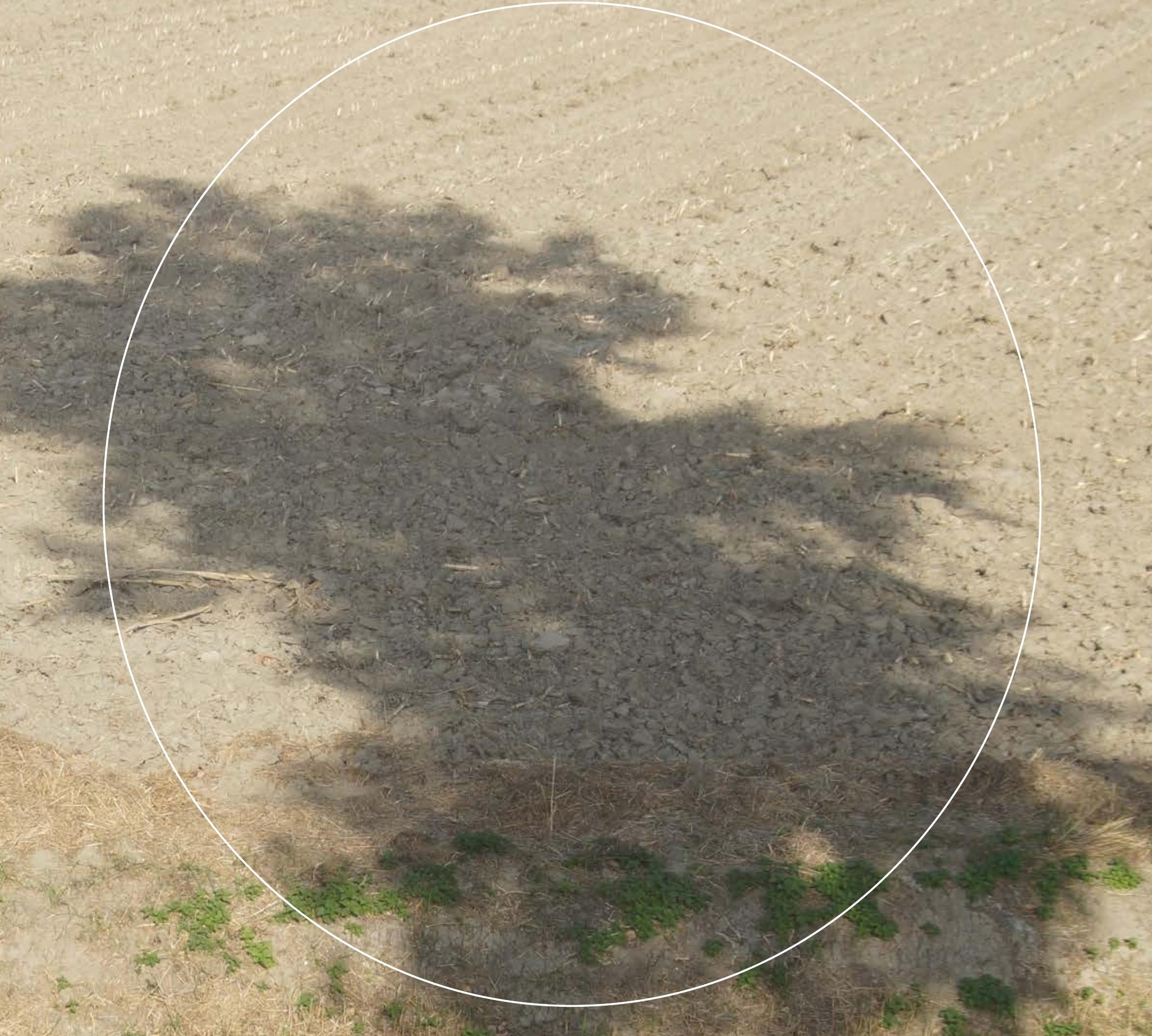

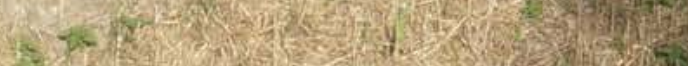

(2) $4+1.2 x$

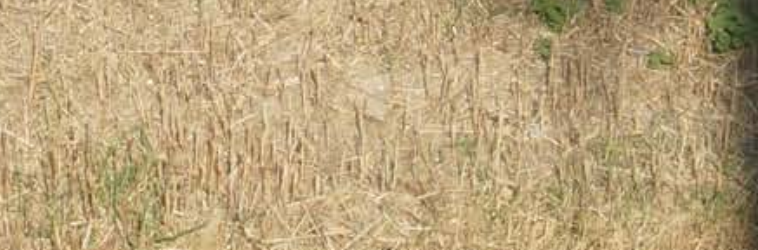

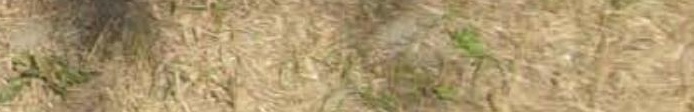

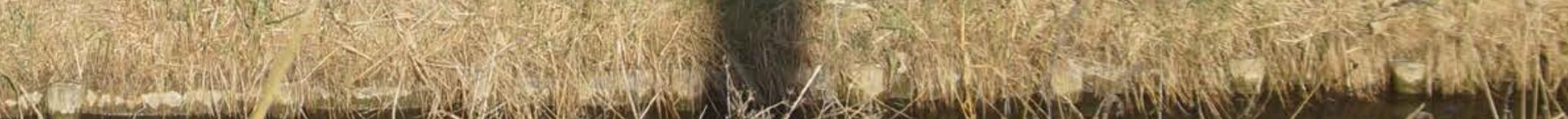

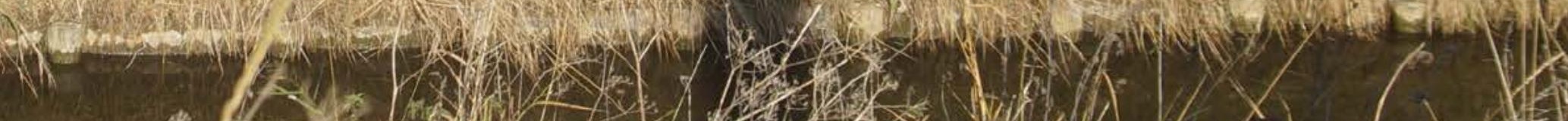




\section{Inhoud}

$\begin{array}{ll}\text { Referaat } & 3\end{array}$

$\begin{array}{ll}\text { Abstract } & 3\end{array}$

$\begin{array}{ll}\text { Woord vooraf } & 4\end{array}$

$\begin{array}{ll}\text { Inhoud } & 6\end{array}$

$\begin{array}{lr}\text { Samenvatting } & 8\end{array}$

$\begin{array}{lr}\text { Summary } & 10\end{array}$

1 Inleiding $\quad 12$

$\begin{array}{ll}1.1 \text { Aanleiding } & 12\end{array}$

$\begin{array}{lr}1.2 \text { Afbakening en doel } & 13\end{array}$

$\begin{array}{ll}1.3 \text { Onderzoeksvraag } & 13\end{array}$

$\begin{array}{lr}1.4 \text { Aanpak } & 13\end{array}$

2 Analytisch raamwerk $\quad 17$

2.1 Culturele normen en zelfidentiteit: goed landschap, goede boer en rondjes rijden 17

2.2 Cultureel en symbolisch kapitaal in relatie tot economisch en sociaal kapitaal 19

$\begin{array}{ll}2.3 \text { Subculturen en bedrijfsstijlen } & 20\end{array}$

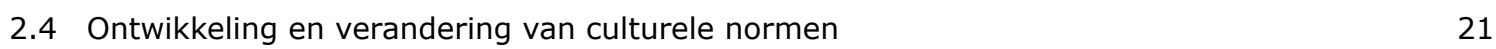

$\begin{array}{ll}2.5 & \text { Synthese en aanpak analyse } \\ \end{array}$

3 Casestudy's $r$

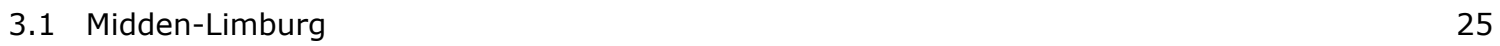

$\begin{array}{ll}3.1 .1 & \text { Typering deelnemende boeren } \\ 3.1 .2 & 25\end{array}$

$\begin{array}{ll}3.1 .2 & \text { Goede boer } \\ 3.1 .3 & 25\end{array}$

$\begin{array}{ll}3.1 .3 \text { Goed land } & 27\end{array}$

$\begin{array}{lll}3.1 .4 & \text { De invloed van culturele normen } & 28\end{array}$

\begin{tabular}{ll}
3.1 .5 & Natuurinclusieve landbouw \\
\hline
\end{tabular}

3.2 Noord-Beveland $\quad 31$

3.2.1 Typering deelnemende boeren $\quad 31$

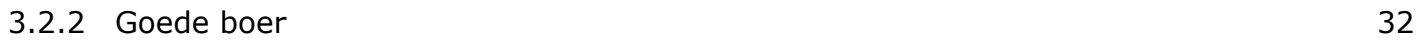

$\begin{array}{ll}3.2 .3 \text { Goed land } & 35\end{array}$

$\begin{array}{ll}3.2 .4 & \text { De invloed van culturele normen }\end{array}$

3.2.5 Natuurinclusieve landbouw $\quad 36$

$\begin{array}{ll}3.3 \text { Achterhoek } & 39\end{array}$

3.3.1 Typering deelnemende boeren $\quad 39$

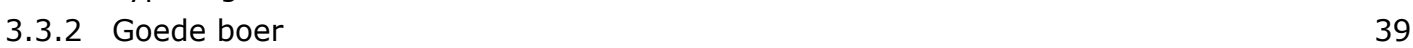

$\begin{array}{ll}3.3 .3 \text { Goed land } & 40\end{array}$

3.3.4 De invloed van culturele normen $\quad 41$

3.3.5 Natuurinclusieve landbouw $\quad 41$

\begin{tabular}{ll}
3.4 & Noordelijke Friese Wouden \\
\hline
\end{tabular}

$\begin{array}{ll}3.4 .1 & \text { Typering deelnemende boeren }\end{array}$

$\begin{array}{ll}3.4 .2 & \text { Goede boer }\end{array}$

$\begin{array}{ll}3.4 .3 \text { Goed land } & 45\end{array}$

$\begin{array}{ll}\text { 3.4.4 De invloed van culturele normen } & 45\end{array}$

$\begin{array}{ll}3.4 .5 & \text { Natuurinclusieve landbouw }\end{array}$

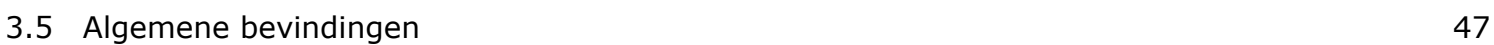

$\begin{array}{ll}3.5 .1 & \text { Vergelijking tussen casestudy's }\end{array}$

$\begin{array}{ll}3.5 .2 & \text { Sociaal geconstrueerde verhalen } \\ \end{array}$ 
4 Analyse $\quad 55$

4.1 Culturele normen en zelfidentiteit $\quad 55$

4.2 Cultureel en symbolisch kapitaal in relatie tot economisch en sociaal kapitaal 56

$\begin{array}{lll}4.3 & \text { Subculturen en bedrijfsstijlen } & 58\end{array}$

\begin{tabular}{ll}
4.4 & Ontwikkeling en verandering van culturele normen \\
\hline
\end{tabular}

$\begin{array}{ll}4.5 \text { Kan een goede boer natuurinclusief zijn? } & 59\end{array}$

$\begin{array}{ll}4.6 \text { Handelingsperspectief } & 61\end{array}$

5 Conclusie $\quad 65$

6 Discussie $\quad 67$

\begin{tabular}{ll}
6.1 & Beperkingen van het onderzoek \\
\hline
\end{tabular}

$\begin{array}{ll}6.2 \text { Toevoegingen aan theorie en literatuur } & 68\end{array}$

$\begin{array}{ll}6.3 \text { Van scheiden naar verweven en integreren } & 68\end{array}$

$\begin{array}{lr}\text { Literatuur } & 70\end{array}$

$\begin{array}{ll}\text { Verantwoording } & 73\end{array}$

Bijlage 1 Factoren die een rol spelen bij keuzes van boeren ten aanzien van natuur 75 


\section{Samenvatting}

\section{Probleemstelling}

Voor een brede beweging richting natuurinclusieve landbouw maakt het veel uit of boeren zelf natuurinclusieve landbouw kunnen zien als een mogelijke en gewenste koers voor hun bedrijf. Dit heeft te maken met wie zij zelf zijn en willen zijn als boer. Uit de internationale literatuur is bekend dat boeren hun zelfidentiteit en beroepstrots als 'goede boer' voor een groot deel afmeten aan culturele normen binnen de sector over wat een 'goede boer' is. Hun bedrijf is de plek waar zij zich ontplooien als goede boer. Net zoals andere beroepsgroepen hebben boeren behoefte om hun vakmanschap te laten zien aan hun collega's en zich met hen te vergelijken. Boeren spreiden hun vakmanschap voor een belangrijk deel ten toon op hun land. Volgens de literatuur rijden boeren rond om elkaars land en vee te beoordelen en kunnen ze status opbouwen of verliezen op basis van hoe het land erbij ligt. Onkruid op het land kan bijvoorbeeld leiden tot verlies aan status binnen de boerengemeenschap. Uit de literatuur is bekend dat sommige boeren om die reden liever niet biologisch worden of aan agrarisch natuurbeheer gaan doen. Culturele normen zijn daarmee een mogelijke barrière in een transitie richting natuurinclusieve landbouw. Over de culturele normen in de Nederlandse landbouw is nog weinig bekend. Het is daarom van belang om te onderzoeken wat Nederlandse boeren verstaan onder 'goede boer' en 'goed landschap' en of natuurinclusieve landbouw daar onderdeel van kan uitmaken. Met name is het relevant om te kijken naar het bestaan van subculturen en naar verandering van culturele normen. Als culturele normen kunnen veranderen, zijn er wellicht ook beïnvloedingsmogelijkheden die een beweging richting natuurinclusieve landbouw kunnen ondersteunen.

\section{Methoden}

In vier Nederlandse casestudy's - Midden-Limburg, Noord-Beveland, Achterhoek en Noordelijke Friese Wouden is met kwalitatieve methoden onderzocht wat culturele normen zijn ten aanzien van 'goede boer' en 'goed landschap'. In elk van deze gebieden zijn zes boeren geïnterviewd die door het agrarisch collectief waren voorgedragen. We hadden hen verzocht geen 'voorlopers' in de natuurinclusieve landbouw voor te dragen, en ook geen boeren zonder enige affiniteit met natuur. Als gevolg hebben we vooral boeren gesproken die minimaal aan agrarisch natuurbeheer doen. Deze 24 boeren zijn zowel individueel geïnterviewd als in focusgroepen per gebied. De gesprekken zijn opgenomen, woordelijk uitgewerkt, gecodeerd en geanalyseerd aan de hand van een analytisch raamwerk. In de analyse is per casestudy gezocht naar zowel overeenkomstige als complementaire aspecten en naar relaties tussen aspecten, zoals tussen wat boeren zeggen over 'een goede boer' en wat ze zeggen over natuurinclusieve landbouw. Vervolgens is gekeken naar overeenkomsten en verschillen tussen de casestudygebieden.

Dit onderzoek zegt niet alles over keuzes van boeren ten aanzien van natuurinclusieve landbouw. We hebben alleen gekeken naar culturele normen in de landbouw, maar het scala aan factoren die meewegen in de keuzes van boeren is veel breder. Ook zegt dit onderzoek niet alles over de rol van culturele normen. Omdat wij geen representatieve steekproef hebben genomen en alleen kwalitatief onderzoek hebben gedaan, kunnen we geen algemene uitspraken doen over culturele normen in de sector als geheel of over de omvang van een 'natuurinclusieve subcultuur'. We hebben een subcultuur onderzocht waar op de kortere termijn winst valt te behalen als het gaat om de beweging richting natuurinclusieve landbouw. In de culturele normen van deze groep verwachtten wij aanknopingspunten te vinden om natuurinclusief in te passen in de culturele norm en de zelfidentiteit. Daarvoor is het nodig om met behulp van kwalitatieve methoden inzicht te verkrijgen in betekenissen.

\section{Belangrijkste bevindingen}

Ons onderzoek bevestigt beelden van 'goede boer' en 'goed landschap' die in de literatuur zijn beschreven: een goede boer zorgt goed voor haar land, vee en grond en is herkenbaar aan een net landschap, vrij van onkruid, strak onderhouden, evenals een goed bijgehouden erf. Ons onderzoek voegt daar echter aspecten aan toe. Een goede boer neemt ook verantwoordelijkheid ten aanzien van milieu, biodiversiteit en maatschappij, is sociaal, 
werkt niet te hard en is gelukkig. Goed land mag er minder netjes uitzien als biodiversiteit een nevendoel is. Daarin kan een boer evengoed vakmanschap ten toon spreiden. Wel moet nog veel vakmanschap worden opgebouwd, zowel om natuurinclusief in de praktijk te kunnen brengen alsook om het te kunnen herkennen bij anderen.

De voorkeur voor een 'net landschap' lijkt niet gunstig voor de ontwikkeling van natuurinclusieve landbouw. Toch bieden de onderzoeksresultaten ook inzicht in hoe natuurinclusieve landbouw wel compatibel kan zijn met culturele normen ten aanzien van 'goede boer' en 'goed landschap'. Diverse boeren hebben aangegeven dat hoe goed land eruit moet zien, afhangt van het doel. En verantwoordelijkheid ten opzichte van milieu en maatschappij behoort voor diverse respondenten bij een goede boer. Ook vertellen verschillende respondenten hoe zijzelf soms letterlijk - anders tegen natuur op het boerenbedrijf aan zijn gaan kijken, en hoe zij culturele normen onder hun collega's zien veranderen. Dit is vaak het gevolg van eigen ervaring met agrarisch natuurbeheer of door het in het landschap zien van agrarisch natuurbeheer bij anderen. Verandering van praktijken kan dus op termijn leiden tot verandering van culturele normen. De agrarische collectieven zijn een voorbeeld van een subcultuur waarin natuurinclusief een goede vorm van landbouw kan zijn, en waarin het vakmanschap wordt ontwikkeld dat nodig is om natuurinclusief in de praktijk te brengen en om het te herkennen op het land van anderen.

Omdat de respondenten in ons onderzoek wel aangeven rondjes te rijden om het land van hun collega's te beoordelen, maar daar in hun eigen beslissingen geen rekening mee zeggen te houden, denken we dat boeren zich steeds meer identificeren met andere subculturen dan alleen de lokale subcultuur. Ze zijn immers niet alleen lid van hun lokale boerengemeenschap, maar behoren ook tot een bepaalde sector en bedrijfsstijl en zijn lid van studiegroepen, coöperaties en/ of het agrarisch collectief. Dit gaat om regionale en landelijke netwerken. De mening en het voorbeeld van collega's doen ertoe om het eigen vakmanschap aan af te meten, maar het is de vraag welke collega's binnen welke subcultuur. Het ontstaan en de groei van natuurinclusieve subculturen kunnen bijdragen aan een transitie van de landbouw doordat daarbinnen een culturele norm wordt ontwikkeld voor 'goed natuurinclusief' waar boeren hun zelfidentiteit aan kunnen afmeten.

In sommige regio's lijken boeren meer open te staan voor natuurinclusieve landbouw dan in andere. Dit kan echter ook te maken hebben met toeval en het kleine aantal respondenten per gebied. De praktische uitwerking van natuurinclusieve landbouw is anders in verschillende landschappen en sectoren.

\section{Handelingsperspectief}

Begrip van de rol van culturele normen in de landbouw is van groot belang voor partijen die beslissingen van boeren zouden willen beïnvloeden, zoals overheden, natuurorganisaties, ketenpartijen en agrarische collectieven. Op basis van dit onderzoek komen wij tot de volgende aanknopingspunten daarvoor:

1 Het framen van biodiversiteit in termen van productie of prestatie

Natuur als teelt met productiedoelen sluit aan bij de denkwereld van veel boeren en daagt hen uit in hun vakmanschap.

2 Het zichtbaar maken van natuurinclusief vakmanschap voor andere boeren

Boeren hebben de behoefte om aan zichzelf en aan collega's te laten zien dat ze een goede boer zijn. Dit doen ze vooral in het landschap, maar er zijn meer mogelijkheden, waaronder het publiceren van monitoringsresultaten.

3 Het bevorderen van de opbouw van natuurinclusief vakmanschap Voor de ontwikkeling van natuurinclusieve culturele normen is het nodig dat boeren ervaring op kunnen doen met natuurinclusieve praktijken, zodat ze die ook bij anderen kunnen herkennen.

4 Het bevorderen van de ontwikkeling van natuurinclusieve subculturen Het is nodig dat boeren erkenning van hun vakmanschap kunnen vinden bij elkaar, en dat zij zich als goede boer kunnen identificeren met anderen. De agrarische collectieven zijn een goed functionerend voorbeeld van een natuurinclusieve subcultuur. 


\section{Summary}

\section{Problem definition}

For bringing about a widespread shift towards nature-inclusive farming it makes a big difference whether or not farmers see nature-inclusive farming as a feasible and desirable farm strategy. This is related to who they are and who they want to be as a farmer. From the international literature it is known that farmers measure their self-identity and the pride they take in their work as a 'good farmer' primarily against the cultural norms within the farming community about what a 'good farmer' is. Their farms are the place where they develop their skill as a good farmer. Just like other occupational groups, farmers feel the need to demonstrate their skill to their colleagues and compare their performance with that of the others. To a large degree farmers demonstrate their occupational skill through the state of their land. According to the literature, farmers drive around to inspect each other's land and livestock, and they can acquire or lose status depending on the appearance of their land. The presence of weeds, for example, can lead to a loss of status within the farming community. From the literature it is known that for this reason some farmers would rather not convert to organic farming or take part in agri-environment schemes. Cultural norms are therefore a potential barrier in a transition to nature-inclusive farming, but little is known about cultural norms in Dutch agriculture. It is therefore important to investigate what Dutch farmers mean by a 'good farmer' and a 'good landscape' and whether or not nature-inclusive farming can be included in those norms. In particular, it is relevant to look at the existence of subcultures and at changes in cultural norms. If cultural norms can change, it may be possible to encourage a shift towards nature-inclusive farming.

\section{Methods}

In four case study areas - Midden-Limburg, Noord-Beveland, Achterhoek and Noordelijke Friese Wouden - qualitative methods were used to investigate the cultural norms that define a 'good farmer' and a 'good landscape'. In each of these areas, six farmers were interviewed who were put forward by the agri-environmental collective. We asked the collectives not to propose any pioneers in nature-inclusive farming or any farmers who have no affinity with nature conservation at all. As a consequence, we mainly spoke to farmers who at least participate in on-farm conservation work. These 24 farmers were interviewed individually and in focus groups for each area. The interviews were recorded, transcribed verbatim, coded and analysed according to an analytical framework. First, the interviews within each case study were analysed for similarities and complementary aspects and for relationships between aspects, such as between what farmers say about 'a good farmer' and what they say about nature-inclusive farming. Then the data were analysed for similarities and differences between the case study areas.

This study does not tell us everything about the choices farmers make regarding nature-inclusive farming. We only looked at cultural norms in agriculture, but the range of factors that influence farmers' choices is much wider than these norms alone. Neither does this study say everything about the role of cultural norms. As we did not take a representative sample and performed a qualitative study only, we cannot draw any general conclusions about cultural norms in agriculture as a whole, or about the size of a 'nature-inclusive subculture'. We investigated a subculture which could make progress in the shift towards nature-inclusive farming on a short term. We expected the cultural norms of this group to contain openings for assimilating nature-inclusive farming into the cultural norm and into farmers' self-image. To identify these openings we needed to obtain insight into meanings, and for that we needed to use qualitative research methods.

\section{Key findings}

Our research confirms the ideas of a 'good farmer' and a 'good landscape' as described in the literature: a good farmer takes good care of her land, her livestock and the soil, and this is reflected in a tidy landscape that is free of weeds and neatly maintained, as well as in a well-kept farmyard. Our research adds other dimensions to this as well. A good farmer takes responsibility for the environment, biodiversity and society, is sociable, does not 
work too hard and is happy. Good land does not have to be quite so neat and tidy if biodiversity is a secondary objective; such a landscape will show off a farmer's competence just as well. However, many skills still need to be acquired, both to put nature-inclusivity agriculture into practice and to recognise it on the land of others.

The preference for a 'tidy landscape' would not appear to be conducive to the development of nature-inclusive farming. And yet the research results also give an indication of how nature-inclusive farming can be compatible with cultural norms regarding the 'good farmer' and the 'good landscape'. Various farmers said that how good land should look depends on its purpose and some respondents said that responsibility for the environment and for society is part of what it means to be a good farmer. Also, a number of respondents described how they have learned to view nature on the farm in a different way - sometimes literally - and how they have seen cultural norms among their colleagues change. This is often the result of farmers' own experiences with agri-environment schemes or of seeing examples in the landscape of agri-environmental management by other farmers. Changing practices can therefore in the longer term lead to changes in cultural norms. The agri-environmental collectives are an example of a subculture in which nature inclusive farming can be a good form of agriculture and in which farmers can develop the occupational skills they need to put nature-inclusive farming into practice and to recognise it in other farmers' land.

Because the respondents in our study said that they drive around to look at their colleague's land but that this does not affect their own farming decisions, we think that farmers are increasingly identifying with subcultures other than their local subculture. After all, they not only belong to their local farming community, but they are also part of a particular agricultural sector and farming style and are members of study groups, cooperatives and/ or the agri-environmental collective. These are regional and national networks. The opinions and examples set by their colleagues are important to farmers in gauging their own skills - but which colleagues and within which subculture? The emergence and growth of nature-inclusive subcultures can contribute to a transition in agriculture because these subcultures develop a cultural norm for 'good nature-inclusive farming' against which farmers can gauge their self-image.

In some regions farmers appear to be more open to nature-inclusive farming than in other regions. However, this may be coincidental due to the small number of respondents per area. Nature-inclusive farming takes on different forms in different landscapes and in different agricultural sectors.

\section{Action strategies}

Understanding how cultural norms affect agricultural practices is essential for organisations that want to influence farmers' decisions, such as public authorities, nature conservation organisations, parties in the value chain and agri-environmental collectives. Based on this study, we propose the following strategies:

1 Frame biodiversity in terms of production or performance

Nature as a crop with production targets fits the mindset of many farmers and challenges them to demonstrate their professional skill and competence.

2 Make nature inclusive farming skills visible to other farmers

Farmers feel the need to prove to their colleagues that they are good farmers. They do this mainly through how they manage the landscape, but there are additional ways, including publishing monitoring results.

3 Facilitate the development of nature inclusive farming skills

In order to develop nature inclusive cultural norms, farmers have to gain experience with nature inclusive practices to be able to recognise them on other farms too.

4 Foster the development of nature inclusive subcultures

Farmers feel the need to have their occupational skills recognised and appreciated by other farmers and to identify with them as good farmers. The agri-environmental collectives are a well-functioning example of a nature-inclusive subculture. 


\section{Inleiding}

\subsection{Aanleiding}

Hoewel 'natuurinclusieve landbouw' in de Rijksnatuurvisie (2014) werd geïntroduceerd als een ontwikkelingsrichting voor de mainstream landbouw, is natuurinclusieve landbouw nu nog verre van mainstream. Dit project wil meer inzicht creëren in de redenen daarvoor, door een focus op de rol van culturele normen bij keuzes van boeren met betrekking tot natuurinclusieve landbouw.

Natuurinclusieve landbouw combineert vermindering van negatieve effecten van landbouw op natuur met het benutten van natuur binnen de bedrijfsvoering en zorg voor natuur (Van Doorn et al., 2016). Agrarisch natuurbeheer is er dus onderdeel van, maar natuurinclusieve landbouw is breder. Er is enig overlap tussen natuurinclusieve landbouw en kringlooplandbouw. Dit betreft met name het vermijden van negatieve effecten van landbouw op natuur door efficiëntere kringlopen, minder aanvoer en lagere emissies. Biologische landbouw heeft overeenkomsten met natuurinclusieve landbouw als het gaat om vermijden van negatieve effecten op natuur (geen chemische middelen) en het benutten van ecosysteemdiensten, maar draagt niet vanzelfsprekend bij aan zorg voor de natuur. Bovendien is biologische landbouw veel nauwkeuriger gedefinieerd, wat zich uit in heldere voorschriften en certificering. Natuurinclusieve landbouw daarentegen is een nog niet scherp gedefinieerd concept. Onder boeren bestaan er verschillende interpretaties van (Westerink et al., 2018). Wel zijn diverse suggesties gedaan met betrekking tot natuurinclusieve praktijken (Erisman et al., 2017; Sanders et al., 2015).

In deze publicatie hanteren we de afbakening van natuurinclusieve landbouw zoals gebruikt in de Kamerbrief van 10 juli 2017 (kader 1), als volgt door ons geïnterpreteerd:

- Niveau 0: alleen wettelijke verplichtingen, niet natuurinclusief

- Niveau 1: betaalde en/ of onbetaalde maatregelen voor soorten en/ of voor landschap op delen van het bedrijf

- Niveau 2: niveau 1 + verbeteren functionele biodiversiteit, optimaliseren van kringlopen op het bedrijf en meer ruimte voor natuurlijk gedrag van dieren.

- Niveau 3: adaptief bedrijfssysteem (het bedrijf als geheel, integraal), natuur past in het bedrijf en het bedrijf past in de omgeving.

\section{Kader 1: Niveaus van natuurinclusieve landbouw volgens Kamerbrief DGAN-NB / 17093609 (10 juli} 2017)

- Niveau 0: Er wordt alleen aan wettelijke verplichtingen voldaan. In de bedrijfsvoering is geen sprake van natuurinclusiviteit.

- Niveau 1: Door op een deel van het land maatregelen te treffen voor specifieke soorten wordt biodiversiteit bevorderd, bijvoorbeeld door maatregelen in het kader van het collectieve agrarisch natuur- en landschapsbeheer, maar ook door nestkastjes op te hangen of door erfbeplanting. Ook biologische plaagbestrijding in kassen hoort bij dit niveau.

- Niveau 2: Er wordt op verbetering van de functionele biodiversiteit gestuurd door optimalisering van kringlopen op het bedrijf, meer ruimte voor het natuurlijk gedrag van dieren, naast beheer van landschapselementen als ondersteuning voor de functionele agrobiodiversiteit en maatregelen ten aanzien van specifieke soorten.

- Niveau 3: Een adaptief systeem, waarbij kringlopen geoptimaliseerd zijn en de geteelde gewassen en gehouden veerassen passen bij de kenmerken en (on)mogelijkheden van de omgeving. Aanleg en onderhoud van landschapselementen en maatregelen voor specifieke soorten zijn integraal onderdeel van de bedrijfsvoering. Het bedrijf vormt één systeem met het omliggende landschap en bedrijven in de buurt. 


\subsection{Afbakening en doel}

Dit onderzoek is uitgevoerd als Kennisontwikkelingsproject van WOt Natuur \& Milieu in opdracht van het Planbureau voor de Leefomgeving (PBL). Het moet bijdragen aan onderzoek in het kader van kennistoepassing, en producten zoals de Natuurverkenning en de Balans van de Leefomgeving. Het PBL adviseert o.a. het ministerie van LNV, bijvoorbeeld in relatie tot het landbouwbeleid. Natuurinclusieve landbouw is een van de onderwerpen waar het PBL aan werkt.

Om keuzes van boeren met betrekking tot natuurinclusieve landbouw te kunnen beïnvloeden, is het nodig om meer zicht te krijgen op factoren die meespelen in hun overwegingen. In Bijlage 1 is een literatuuroverzicht opgenomen dat laat zien dat diverse factoren een rol spelen bij keuzes van boeren ten aanzien van natuur (biodiversiteit, milieu). Bij de ontwikkeling van strategieën om natuurinclusief gedrag van boeren te bevorderen, is het belangrijk om het hele scala aan factoren in het oog te houden dat de keuze van boeren beïnvloedt. In dit onderzoek is echter ingezoomd op culturele normen ten aanzien van 'goede boer' en 'goed landschap', omdat het vermoeden bestaat dat deze een belangrijke rol spelen, maar er in de Nederlandse situatie nog weinig over bekend is. Daarmee is dit onderzoek een aanvulling op onderzoek dat recent bij PBL en WUR is uitgevoerd (Bouma and Koetse, 2020; Bouma et al., 2019; Krom and Prins, 2019; Westerink et al., 2018).

Voor een transitie richting natuurinclusieve landbouw is het belangrijk dat grote groepen boeren dat zien als een ontwikkelingsrichting die bij hen zou kunnen passen en ook haalbaar is. Het PBL is in het kader van dit onderzoek daarom minder geïnteresseerd in de overwegingen van "koplopers" dan in de afwegingen van mogelijke "volgers": voor een groei in het aantal natuurinclusieve bedrijven is het noodzakelijk dat juist deze laatste groep beter wordt begrepen.

Doel van het project is meer inzicht te krijgen in de rol van culturele normen binnen de boerengemeenschap in de keuzes van boeren om al dan niet een natuurinclusieve koers voor hun bedrijf in te slaan. Dit moet aanknopingspunten bieden voor beleid van overheden en anderen dat boeren effectief ondersteunt in die ontwikkeling.

\subsection{Onderzoeksvraag}

De titel van dit rapport is tevens de centrale vraag van dit onderzoek: "Kan een goede boer natuurinclusief zijn?" Daaronder liggen de volgende onderzoeksvragen:

1 Wat is een goede boer volgens boeren?

2 Aan welk landschap herkennen boeren een goede boer?

3 Welke rol spelen deze culturele normen en het oordeel van collega's bij keuzes van boeren met betrekking tot hun bedrijfsvoering?

4 In hoeverre is 'natuurinclusief' verenigbaar met het beeld van een 'goede boer' en een 'goed landschap'?

5 Is er sprake van verandering van deze culturele normen, en van subculturen? Verschillen culturele normen per gebied?

6 Hoe zijn deze inzichten te vertalen naar mogelijkheden voor sturing?

\subsection{Aanpak}

Gestart is met een verkenning naar mogelijke barrières voor boeren om een natuurinclusieve koers voor hun bedrijf in te slaan. Deze verkenning bestond uit een beperkte literatuurstudie (Bijlage 1 ). Vervolgens is in een workshop bij het PBL in april 2018 gesproken over een verdere afbakening voor een verdiepende studie naar de relatie tussen factoren en gedrag. Het onderzoek is uiteindelijk toegespitst op de rol van culturele normen.

Voor de verdiepende fase is gekozen voor 4 casestudy's om een beter beeld te krijgen van culturele normen binnen boerengemeenschappen in verschillende gebieden. Criteria voor de keuze van casestudy's waren: 
- Een spreiding over Nederland.

- Diversiteit: verschillen in landschapstypen en bedrijfssystemen.

- Bij voorkeur binnen de gebieden van de natuurinclusieve Gemeenschappelijk Landbouwbeleid (GLB) pilots.

- Bereidheid van het agrarisch collectief om mee te werken.

- Aanvulling op de casestudy's Eemland en Flevoland van Boeren in Beweging.

We vermoedden dat culturele normen deels regionaal zijn bepaald. Gekozen is voor een spreiding van casestudy's om inzicht te krijgen in de breedte van culturele normen binnen Nederland, de relatie met het landschap en bijbehorende bedrijfssystemen, en om onze hypothese te toetsen dat regionaal maatwerk nodig is voor het stimuleren van natuurinclusieve landbouw.

De volgende casestudy's zijn gekozen:

- Noord-Beveland (Zeeland) i.s.m. Poldernatuur: open polderlandschap met akkerbouw

- Noordelijke Friese Wouden (Friesland) i.s.m. Noardlike Fryske Wâlden: open veenweidegebied met melkveehouderij

- Achterhoek (Gelderland) i.s.m. VALA: kleinschalig landschap met meerdere bedrijfstypen (respondenten waren vooral melkveehouders)

- Midden-Limburg i.s.m. Natuurrijk Limburg: kleinschalig landschap met meerdere bedrijfstypen

\section{Kader 2: Bepalen van de doelgroep}

Van Herzele et al. (2013) onderscheiden verschillende redenen voor deelname aan agrarisch natuurbeheer:

1 Opportunistisch: het levert een betaling op voor wat de boer toch al doet

2 Calculerend: de opbrengsten van deelname zijn hoger dan de kosten

3 Compenserend: deelname om het beste te maken van het moeten voldoen aan regelgeving

4 Optimaliserend: deelname om het beste te maken van de fysieke omstandigheden (landschap, bodem)

5 Katalyserend: het kunnen uitvoeren van maatregelen die zonder betaling niet haalbaar zijn

6 Betrokken: de boer wil natuur integreren in het bedrijf en zet Agrarisch Natuur en Landschapsbeheer (ANLb) daarbij in.

De eerste drie groepen hebben vooral financiële motieven en kiezen de eenvoudige maatregelen. De optimaliserende groep heeft te maken met fysieke omstandigheden in het landschap die een hoge productie in de weg staan, en kiest relatief vaak voor 'medium' maatregelen. De katalyserende groep denkt vanuit de milieumaatregelen en is bereid om een mix van lichte, medium en zware maatregelen te nemen, als die mogelijk worden gemaakt bijvoorbeeld door middel van financiële ondersteuning. Zwaardere maatregelen worden vooral gekozen door de zesde groep ('betrokken'). Dit zijn de voorlopers, zij trekken hun eigen plan, en trekken zich weinig aan van de mening van collega's. Voor ons onderzoek is het minder zinvol om deze laatste groep te onderzoeken, omdat dat waarschijnlijk geen goed inzicht geeft in de overwegingen van de andere groepen.

Gekozen is om agrarische collectieven te vragen om boeren te benaderen voor het onderzoek. De collectieven leverden per collectief zes namen en adressen van bereidwillige leden aan de onderzoekers. De collectieven werden gevraagd niet op zoek te gaan naar natuurinclusieve koplopers, en ook niet naar boeren die geen enkele interesse hebben in natuur, maar de groep ertussenin (van een van de deelnemers in Limburg kunnen we achteraf wel zeggen dat hij een koploper is). Van koplopers verwachten we dat ze zich niet veel gelegen laten liggen aan culturele normen, ze varen hun eigen koers en steken hun kop boven het maaiveld uit (zie Kader 2). Van de boeren zonder enige interesse in natuur verwachten we weinig beweging richting natuurinclusieve landbouw. Op de korte termijn is de meeste winst naar onze verwachting te behalen bij de groep ertussenin, die bijvoorbeeld al wel betrokken zijn bij het agrarisch natuur- en landschapsbeheer, maar hun bedrijf daar niet volledig op hebben ingericht. De deelnemers werd $€ 100$,- vacatiekosten toegezegd. Intussen werden de vragenlijsten voor de individuele en groepsgesprekken definitief gemaakt in afstemming met PBL. 
$\mathrm{Na}$ de individuele interviews brachten we de individuele boeren per gebied bijeen in een focusgroep om de culturele normen te observeren zoals deze in hun interactie worden geconstrueerd. De volgende aanpak is gehanteerd voor de interviews en groepsgesprekken:

- Semigestructureerd

- Geluidsopname

- Verwijzen naar definitie Natuurinclusieve Landbouw (NIL) in de kamerbrief

- Woordelijk uitwerken van opname

- Content analysis o.b.v. codering

De volgende codes zijn gebruikt voor de analyse:

\begin{tabular}{ll} 
Code & Toelichting \\
\hline zelf & Goede boer (zelfidentiteit) \\
\hline drijf & Drijfveren \\
\hline goed alg & Goede boer (algemeen) \\
\hline goed cult & Goede boer: wat geeft status (culturele norm) \\
\hline slecht & Slechte boer (algemeen) \\
\hline slecht cult & Slechte boer (culturele norm) \\
\hline land & Goed landschap (indiv) \\
\hline land cult & Goed landschap (culturele norm) \\
\hline nil & Natuurinclusieve Landbouw \\
\hline meer & Wat zou helpen om meer voor natuur te doen \\
\hline oordeel & Boeren die elkaar beoordelen \\
\hline samen & Cultuur van samenwerking \\
\hline anticipatie & Wat je je aantrekt van de mening van andere boeren \\
\hline leren & Leren van elkaar \\
\hline
\end{tabular}

De analyse is per casestudy gedaan, om vergelijking tussen casestudy's mogelijk te maken. Per boer zijn in grote tabellen per code de uitspraken samengevat voor zowel het individuele interview als de uitspraken in de focusgroep. Daarnaast is op zoek gegaan naar gezamenlijke constructies in de focusgroepen. De tabellen zijn opnieuw gecodeerd voor overeenkomstige uitspraken, verbanden tussen codes, uitspraken over cultuurverandering en vaardigheden om 'goed natuurinclusief' te herkennen. We hebben configurerende en aggregerende analyse gecombineerd. Ter illustratie: per casestudy is de volle breedte van de noties van 'goede boer' in beeld gebracht (3.1.2, 3.2.2, 3.3.2, 3.4.2), waarna deze tussen casestudy's zijn vergeleken (3.5.1) en uiteindelijk geaggregeerd tot een samenvatting (4.1). 


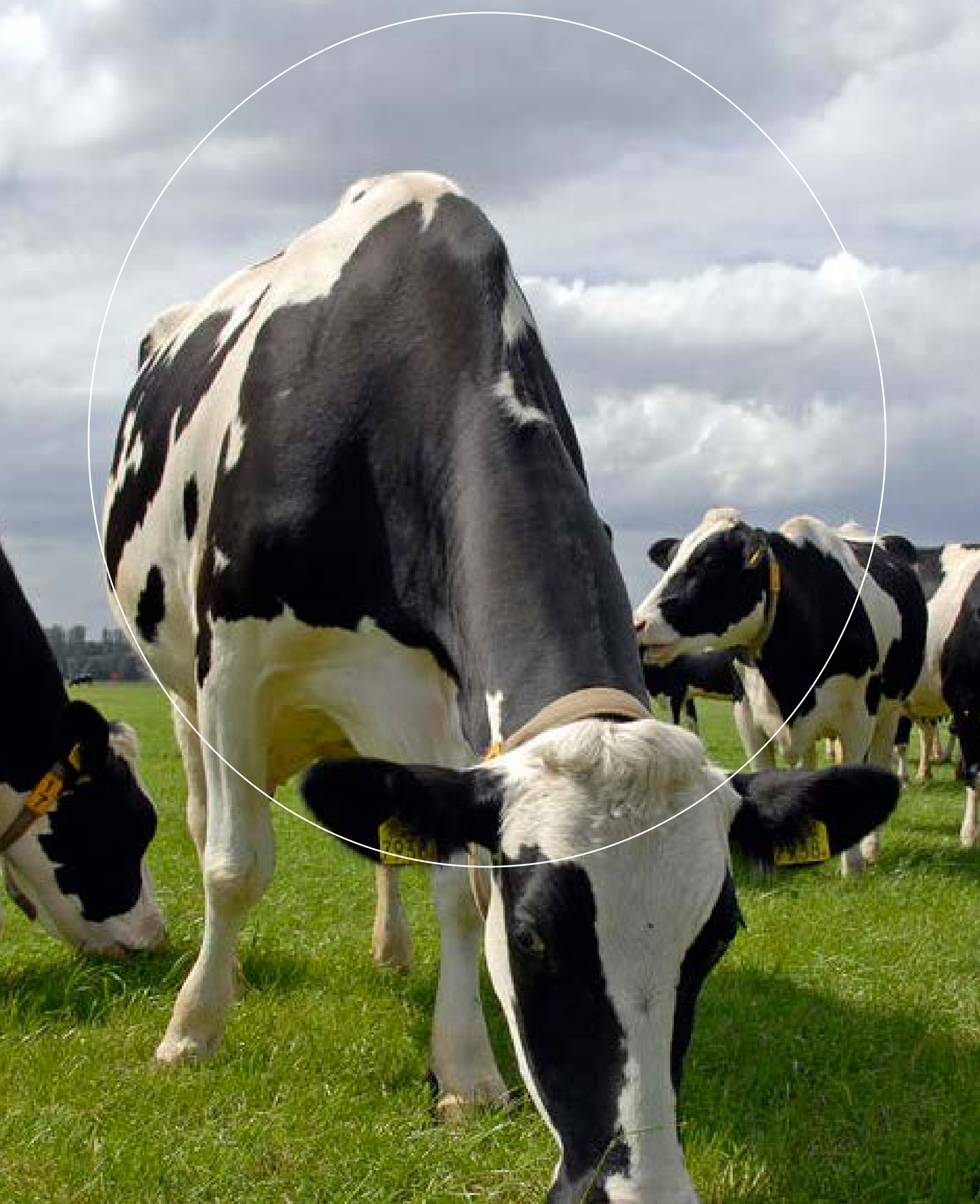
C.

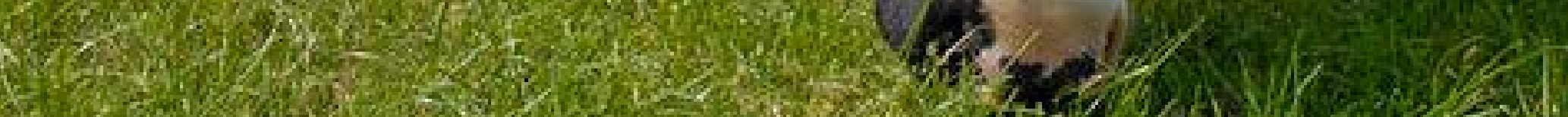

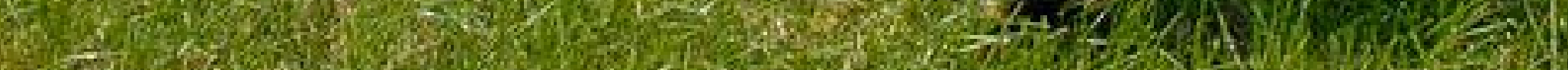

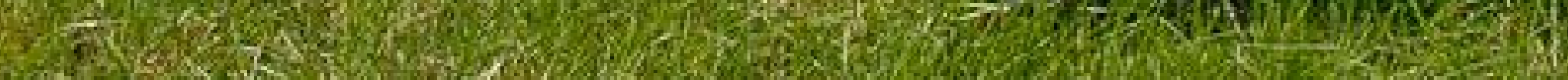
H. 


\section{Analytisch raamwerk}

Met culturele normen bedoelen we de waarden en normen binnen een boerengemeenschap, die bepaald gedrag afkeuren en ontmoedigen of juist goedkeuren en bevorderen. In het bijzonder gaan we in op culturele normen die een 'goede boer' en een 'goed landschap' beschrijven. We vermoeden dat deze normen mede bepalen of boeren natuurinclusieve landbouw zien als iets dat bij hen past en/ of als iets dat hun status in de boerengemeenschap kan versterken of ondermijnen. Als boeren natuurinclusieve landbouw niet kunnen verenigen met hun zelfidentiteit en culturele normen, kan dat een serieuze barrière vormen voor een brede beweging richting natuurinclusieve landbouw. Het empirisch onderzoek waarvan de resultaten in hoofdstuk 3 zijn weergegeven, gaat uit van deze probleemstelling, mede geïnspireerd door vergelijkbaar onderzoek van Burton et al. (2008) over deelname aan subsidieregelingen voor agrarisch natuurbeheer. In dit hoofdstuk werken we het analytisch raamwerk daarvoor uit.

Wij zien culturele normen als nauw verbonden met de praktijk van boeren. We houden er rekening mee dat culturele normen niet uniform en statisch zijn, maar dat er subculturen bestaan en dat culturele normen kunnen ontwikkelen en veranderen in de tijd. We onderzoeken deze aspecten door het combineren van de concepten 'goede boer' en 'goed landschap' van (met name) Burton (2004) met vormen van kapitaal van Bourdieu (1986) om beter te begrijpen waarom het landschap zo'n sterke relatie heeft met identiteit en vakmanschap. We gaan in op de bedrijfsstijlen van Van der Ploeg (o.a. 2009) en subculturen van Vanclay (1998) om zicht te krijgen op diversiteit, en op structuratietheorie van Giddens (1984) om te onderzoeken of verandering van culturele normen aannemelijk is. Burton en Paragahawewa (2011) hebben zelf 'goede boer' en 'goed landschap' uitgewerkt op basis van cultureel kapitaal van Bourdieu. Vanclays subculturenconcept maakt gebruik van 'goed boeren' (los van Burton) en hij heeft de wens deze volgens het denken van Bourdieu verder uit te werken, maar gaat in plaats daarvan het gesprek aan met de bedrijfsstijlen van Van der Ploeg. Burton en Wilson (2006) kijken naar Giddens om te verklaren waarom culturele normen in de landbouw maar zo langzaam veranderen. Doordat deze auteurs de concepten deels al met elkaar in verband hebben gebracht, denken wij dat ze elkaar goed aanvullen.

Door het combineren van de concepten komen we tot een raamwerk waarmee we de empirische resultaten analyseren in hoofdstuk 4.

\subsection{Culturele normen en zelfidentiteit: goed landschap, goede boer en rondjes rijden}

In een Engels akkerbouwgebied vertellen boeren dat ze meer herbicide gebruiken in percelen die goed zichtbaar zijn vanaf de weg (Burton, 2004). Ze weten namelijk dat hun collega's rondjes rijden om het land van de buren te beoordelen en te vergelijken met hun eigen land. Percelen met weinig onkruid worden beschouwd als een uiting van vakmanschap. Het is goed land, dat blijkbaar door een goede boer wordt beheerd. Omdat de boeren onder hun collega's bekend willen staan als goede boer, zorgen ze ervoor dat de vanaf de weg zichtbare stukken land extra goed zijn bijgehouden, zelfs als dat weinig extra voordeel oplevert voor de opbrengst. Hun status legt op dat moment meer gewicht in de schaal dan de kostenoverweging.

Ook andere symbolen voor vakmanschap, als zichtbaar bewijs van 'een goede boer' ('good farmer'), zijn beschreven in de literatuur. Dezelfde Engelse casestudy benoemt goed onderhouden hagen als symbool. In twee andere Engelse casestudy's komen goed verzorgde bedrijfsgebouwen en velden zonder onkruid naar voren (Sutherland, 2013). Akkerbouwers in Duitsland hechten belang aan rechte, parallelle rijpaden (Burton et al., 2008). Duitse en Schotse veehouders beoordelen elkaars vee op uiterlijke kenmerken van conditie (ibid.). Sommigen houden daar rekening mee door hun beste vee in goed zichtbare percelen te zetten. Dergelijk gedrag van vertoon van vakmanschap is ook wel 'roadside farming' genoemd (o.a. Burton, 2004). 
Door zich te vergelijken met anderen, bevestigen boeren hun zelfidentiteit ofwel hun beeld van zichzelf als goede boer (Lokhorst et al., 2011). Lokhorst koppelt zelfidentiteit aan gedrag door het te omschrijven als 'ik ben iemand die zoiets wel/ niet zou doen' en deed onderzoek in Zeeland. Op die manier zou natuurinclusieve landbouw iets kunnen zijn dat boeren zien als iets dat wel of niet bij hen past, dat zij wel of niet zouden doen, dat wel of niet hoort bij een goede boer. En dat beeld van zichzelf wordt deels afgemeten aan het beeld dat collega's hebben van een goede boer (de culturele norm) (Burton and Wilson, 2006; McGuire et al., 2013). Dit is vergelijkbaar met de bevindingen van Wauters et al. (2017), die een relatie vonden tussen de groepsnorm en de persoonlijke norm.

Volgens empirische studies buiten Nederland (Verenigd Koninkrijk, Duitsland, Zweden, Verenigde Staten) is de culturele norm van een goede boer als volgt: een goede boer werkt hard en netjes, haalt het beste uit het land, heeft een goede opbrengst, is geen milieuvervuiler, beheerst het werken met machines, zorgt goed voor het vee, en is een goede buur (Burton, 2004; Burton et al., 2008; McGuire et al., 2013; Saunders, 2016; Sutherland and Burton, 2011).

Volgens Burton (2004) zijn zichtbare symbolen belangrijk voor boeren om hun vakmanschap te tonen en zich met elkaar te vergelijken, omdat ze over hun inkomen weinig controle hebben als gevolg van hun gebrek aan invloed op marktprijzen voor landbouwproducten. Inkomen is daarmee geen geschikte indicator om onderscheid te maken tussen 'goede' en 'slechte' boeren. Het landschap is hiervoor echter wel geschikt. Het is een van de voornaamste zichtbare symbolen omdat hier een groot deel van het werk van de boer plaats vindt. Zij kan hier o.a. laten zien dat zij het vee goed verzorgt, het werken met machines goed beheerst (rechte voren en rijpaden), aandacht besteedt aan het gewas (geen onkruid) en goede opbrengsten weet te halen (egaal gezond gewas). Verschillende auteurs beschrijven een voorkeur van boeren voor een net landschap ('tidy landscape': o.a. De Krom, 2017; Schmitzberger et al., 2005 op basis van onderzoek in resp. Vlaanderen en Zwitserland). Een net landschap komt volgens de theorie van Burton niet alleen voort uit rationele overwegingen van zo efficiënt mogelijk werken en zo hoog mogelijke opbrengsten halen, maar ook uit de behoefte om vakmanschap ten toon te spreiden en door collega's gezien te worden als een goede boer.

Een net landschap staat echter haaks op de condities voor biodiversiteit op boerenland. Biodiversiteit is immers gebaat bij rommelhoekjes, (on-)kruiden, achtergelaten gewasresten en diversiteit in structuur van landschap en gewas. Sutherland (2013) vond dat Engelse boeren weinig interesse hebben om naar biologische landbouw om te schakelen omdat ze daarmee minder goed hun vakmanschap kunnen tonen gezien de lagere opbrengsten en het meer vóórkomen van onkruiden. Burton et al. (2008) verklaren de lage deelname aan subsidieregelingen voor agrarisch natuurbeheer in Engeland uit een lage compatibiliteit van dat agrarisch natuurbeheer met culturele normen ten aanzien van 'goede boer' en 'goed landschap' en de beperkte mogelijkheden voor boeren om hun vakmanschap te laten zien binnen de regelingen. Tegelijkertijd bevestigen de regelingen dat natuur eigenlijk niet bij landbouw hoort door de mogelijkheid te bieden om land uit productie te halen en er een hek omheen te zetten. Volgens Burton et al. (2008) en Sutherland (2013) is het nodig dat specifiek vakmanschap wordt opgebouwd voor agrarisch natuurbeheer en biologische landbouw en er symbolen voor worden ontwikkeld die tentoon kunnen worden gespreid en 'leesbaar' zijn voor anderen. Een hoog aantal nesten en het vóórkomen van zeldzame soorten zijn bijvoorbeeld niet geschikt voor 'roadside farming'. De auteurs bevelen aan dat:

- Boeren de gelegenheid krijgen om het agrarisch natuurbeheer te innoveren en daarmee zowel vakmanschap te ontwikkelen als de link leren leggen tussen hun vakmanschap en de ecologische resultaten;

- Agrarisch natuurbeheer gericht wordt op het integreren van natuur in de landbouwpraktijk (in plaats van de scheiding te blijven reproduceren);

- Met resultaatgerichte betalingen beter wordt ingespeeld op de behoefte van boeren om te 'produceren' en het beter te doen dan anderen;

- Kennisuitwisseling en samenwerking tussen boeren wordt gestimuleerd;

- Biologische boeren de gelegenheid krijgen te laten zien dat ze op moderne en toekomstgerichte wijze goed zorgen voor hun vee en hun land. 


\subsection{Cultureel en symbolisch kapitaal in relatie tot economisch en sociaal kapitaal}

Burton and Paragahawewa (2011) plaatsen de 'goede boer' en het 'goede landschap' in het kader van het concept van kapitaal van Bourdieu. Bourdieu (1986) onderscheidt drie vormen van kapitaal - economisch, cultureel en sociaal kapitaal - die tot op zekere hoogte uitwisselbaar zijn via een vierde vorm van kapitaal: symbolisch kapitaal, en door de investering van tijd (zie figuur 1 ).

Economisch kapitaal is direct om te zetten in geld en kan geïnstitutionaliseerd zijn middels eigendomsrechten.

- Sociaal kapitaal is het gevolg van lidmaatschap van een groep en betekent toegang tot het gezamenlijke kapitaal. Sociaal kapitaal bestaat uit sociale plichten en netwerken van mensen die elkaar kennen en waarin wederzijdse erkenning (van het lidmaatschap van of de positie binnen de groep) belangrijk is. Ieder lid is mede verantwoordelijk voor het afbakenen van wat de groep onderscheidt van niet-leden. Sociaal kapitaal kan geïnstitutionaliseerd zijn in bijvoorbeeld adellijke titels of in leiderschapsfuncties ('voorzitter').

- Cultureel kapitaal heeft drie vormen:

- Belichaamd ('embodied') cultureel kapitaal bestaat uit zaken als goede manieren, kennis en vaardigheden en is het resultaat van opvoeding, onderwijs, oefening en ervaring en vraagt een tijdsinvestering om op te bouwen. Belichaamd cultureel kapitaal is persoonsgebonden en kan niet worden verkocht of overgedragen zonder dat zowel de overdrager als de ontvanger er (veel) tijd in investeren.

- Geobjectiveerd ('objectified') cultureel kapitaal is vastgelegd in materiële objecten zoals boeken, schilderijen en machines. Deze objecten kunnen worden overgedragen en worden omgezet in economisch kapitaal (verkocht), maar voor de productie en het gebruik ervan is belichaamd cultureel kapitaal nodig, die de gebruiker ofwel zelf heeft, ofwel inhuurt via dienstverlening.

- Geïnstitutionaliseerd ('institutionalized') cultureel kapitaal is een vorm van formele erkenning van belichaamd cultureel kapitaal in de vorm van bijvoorbeeld diploma's en academische titels.

- Symbolisch kapitaal vertegenwoordigt de waarde of status die verleend wordt aan vakmanschap/ vaardigheid, objecten, diploma's, titels en de schaarste daarvan. Het gaat om de betekenis die aan de verschillende vormen van kapitaal wordt gegeven en het prestige of de reputatie die het de houder oplevert. Het vergt belichaamd cultureel kapitaal en sociaal kapitaal om die betekenis te 'lezen'.

Burton and Paragahawewa (2011) zien het concept van een 'goede boer' als cultureel kapitaal, belichaamd in het vakmanschap van de boer, geobjectiveerd in 'goed land' en in machines, en geïnstitutionaliseerd in certificaten en prijzen binnen de landbouw. Een groot deel van dit cultureel kapitaal wordt overgedragen van de ene generatie op de andere. Cultureel kapitaal levert symbolisch kapitaal op in de vorm van status binnen de boerengemeenschap: het faciliteert de opbouw van sociaal kapitaal. Boeren hebben belichaamd cultureel kapitaal nodig om een 'goede boer' van een slechte te onderscheiden, en om objecten te produceren die bewijzen dat ze een 'goede boer' zijn (waaronder landschap). Nogmaals, deze objecten moeten zichtbaar zijn voor collega's om symbolisch kapitaal op te leveren (Burton et al., 2008). Daarom is het landschap daarvoor zo'n belangrijk symbool en rijden boeren rondjes om elkaars land (en daarmee elkaar en zichzelf) te beoordelen.

Sutherland (2013) zoekt een verband tussen het cultureel kapitaal van de 'goede boer' en economisch kapitaal met behulp van een ander concept van Bourdieu: persoonlijke voorkeur als gevolg van noodzaak ('taste of necessity') (Bourdieu, 1984). In de geschiedenis van de landbouw is het noodzaak geweest om te werken aan goede opbrengsten en gezond vee. Het is dan ook niet verwonderlijk dat symbolen van productiviteit, economisch verstandige keuzes en economische voorspoed onderdeel zijn gaan uitmaken van het beeld van een 'goede boer' en een 'goed landschap' (Sutherland, 2013). 


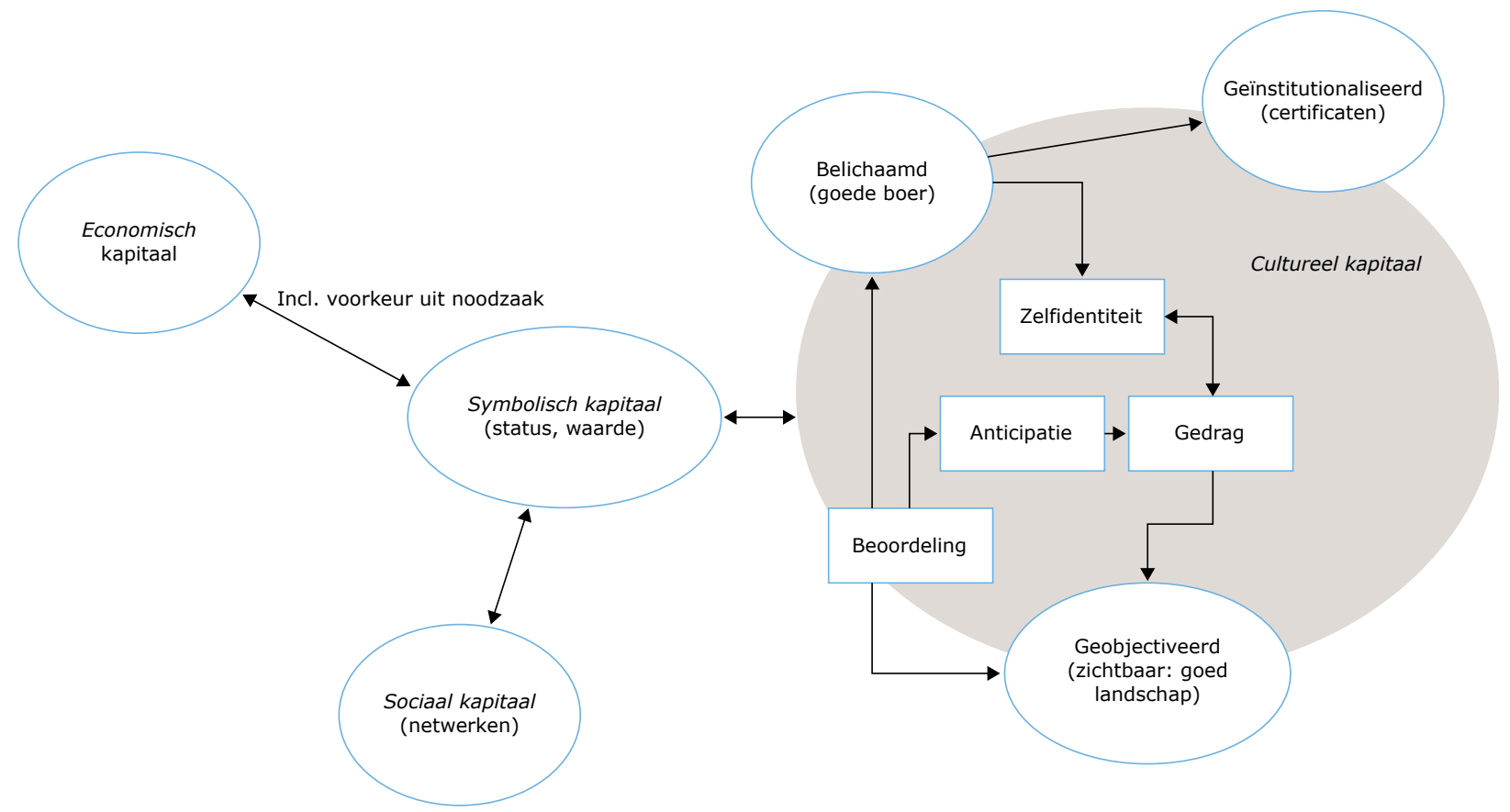

Figuur 1 Beelden van 'goede boer' en 'goed landschap' als vormen van cultureel kapitaal en de rol van symbolisch kapitaal als vertaler tussen cultureel, sociaal en economisch kapitaal. Gebaseerd op Bourdieu 1986 en Burton \& Paragahawewa 2011.

\subsection{Subculturen en bedrijfsstijlen}

Volgens Vanclay et al. (1998) vormt de wens tot 'goed boeren' (good farm management) de belangrijkste motivatie van boeren. 'Goed boeren' betreft noties over alle aspecten van de landbouwpraktijk. Concepten van 'goed boeren' worden gevormd door interpretaties van boeren, interacties tussen boeren, en ook beïnvloed door anderen, zoals voorlichters. Vanclay et al. zien concepten van 'goed boeren' als sociale constructies die zullen verschillen tussen verschillende groepen boeren, tussen landbouwsectoren en tussen regio's. Clusters van samenhangende ideeën over 'goed boeren' kunnen als subculturen worden gecategoriseerd. Sutherland (2013) laat zien dat 'goed boeren' en 'goed landschap' een wat andere betekenis hebben voor biologische ten opzichte van gangbare boeren; biologische boeren leggen bijvoorbeeld meer nadruk op de omgeving.

Ook het bedrijfsstijlenconcept ('styles of farming'/ 'farming styles') gaat uit van diversiteit binnen de landbouw in wat als 'goede landbouw' wordt beschouwd (Van der Ploeg and Ventura, 2014). Een bedrijfsstijl is zowel een verzameling ideeën als een praktijk. Van der Ploeg et al. (2009) definiëren een bedrijfsstijl als een combinatie van:

- Een samenhangende verzameling strategische noties over de manier waarop landbouw zou moeten worden gepraktiseerd ('cultureel repertoire')

- Een bepaalde, intern samenhangende manier van boeren (praktijk)

- Een specifieke verzameling relaties tussen landbouw enerzijds en techniek en markt anderzijds.

De praktijk wordt hierbij vorm gegeven vanuit het cultureel repertoire en het cultureel repertoire wordt gereproduceerd en bijgesteld door de praktijk. Bedrijfsstijlen bestaan naast elkaar en verklaren gezamenlijk de diversiteit in de landbouw. Een bedrijfsstijl vertegenwoordigt een lange-termijn oriëntatie op het strategische niveau, wat heroriëntatie niet uitsluit: boeren kunnen van bedrijfsstijl veranderen. Persoonlijke voorkeur is een belangrijke verklaring voor verschillende bedrijfsstijlen van boeren in vergelijkbare situaties (Brodt et al., 2006; Schmitzberger et al., 2005). Verschillende bedrijfsstijlen beïnvloeden het landschap anders (Primdahl, 1999; Schmitzberger et al., 2005). Schmitzberger et al. vonden een relatie tussen bedrijfsstijl, intensiteit van het landgebruik en biodiversiteit op het bedrijf. 
Een groot deel van de bedrijfsstijlenliteratuur zoekt naar categoriseringen zoals die binnen de boerengemeenschap zelf worden gehanteerd. Dat heeft geleid tot diverse onderverdelingen met verschillende aantallen categorieën (resp. 3, 8 en 4 in Brodt et al., 2006; Schmitzberger et al., 2005; Van der Ploeg and Ventura, 2014). Een voorbeeld is de verdeling in 'koeienboeren', 'machineboeren', 'ondernemers' en 'economische boeren'. Deze vertegenwoordigen verschillen in oriëntatie op productie (veel of weinig input) en op ontwikkeling (weinig of sterk gericht op groei) (Van der Ploeg et al., 2009). Door het gebruik van termen die boeren gebruiken om zichzelf en elkaar te beschrijven ${ }^{1}$, hebben bedrijfsstijlen een sterke relatie met zelfidentiteit.

Volgens Burton and Wilson (2006) is het veel te simpel om voor individuele boeren een enkelvoudige identiteit vast te willen stellen. Boeren putten uit meerdere identiteiten (bijvoorbeeld die van producent, ondernemer, verbreder en milieubeschermer) om hun positie en gedrag te bepalen, waarbij het relatieve belang van iedere identiteit afhankelijk is van de situatie. Hun identiteit bestaat dan niet alleen uit wat ze wel zijn, maar ook uit wat ze niet (willen) zijn.

\subsection{Ontwikkeling en verandering van culturele normen}

Sommige auteurs merken op dat beelden van 'goede boer' en 'goed landschap' aan het verschuiven zijn, en dat zorg voor de natuur door boeren ook als goede landbouwpraktijk kan worden beschouwd (Mills et al., 2016; Sutherland, 2010; Wilson and Hart, 2000). Burton and Wilson (2006) zijn echter sceptisch over een veronderstelde verschuiving van een productivistisch discours naar milieubewust en multifunctioneel. Zij plaatsen verandering van culturele normen in de landbouw in het kader van de structuration theory van Anthony Giddens (1984). Volgens deze theorie worden de handelingen van actoren (agency) beperkt èn mogelijk gemaakt door structuren. Structuren zijn kenmerken van sociale systemen, met name regels, middelen en discoursen. Individuen zijn niet bij machte om deze structuren te veranderen. Door hun handelingen reproduceren actoren de structuren, maar de optelsom van hun handelingen draagt wel bij aan transformatie van structuren. Wij beschouwen culturele normen als structuur (in de vorm van discours), en de boeren en hun praktijken als agency². Op die manier is het verklaarbaar dat culturele normen slechts langzaam veranderen. Maar die verandering gebeurt dus wel degelijk als steeds meer boeren hun praktijken veranderen (zie figuur 2).

Sutherland (2013) laat zien dat de groei van het aantal biologische bedrijven in haar casestudy's in Engeland heeft geleid tot bijstelling van het beeld van biologische boeren onder gangbare boeren: waar ze eerder vooral als niet-realistische rommelaars werden gezien, was biologisch inmiddels 'ook een vorm van goede landbouw'. Dat kwam doordat boeren met name bij omgeschakelde bedrijven hadden gezien dat biologische boeren ook goed voor hun land en hun vee kunnen zorgen en dat het een economisch verstandige keuze kan zijn. Daarmee is de culturele norm niet omgeslagen: een productief landschap is nog steeds de kern van goede landbouw, maar het milieu is er (meer) onderdeel van geworden.

McGuire et al. (2013) zagen een verandering in het beeld van de 'goede boer' als rolidentiteit bij een groep akkerbouwers in een stroomgebied in Iowa (VS), als gevolg van kritiek van buitenaf (gemeten vervuiling van het water) en een programma van vrijwillige milieumaatregelen in combinatie met metingen van resultaten en bespreking daarvan in groepen boeren. De confrontatie met de aantijging 'milieuvervuilers' te zijn, het ontwikkelen van nieuwe praktijken en het (onderling) leren waren volgens de auteurs de situaties waarin de boeren hun rolidentiteit bijstelden.

1 Vaak werden in bedrijfsstijlenonderzoek boeren gevraagd om zichzelf te identificeren met een 'portret'. Die portretten waren gemaakt op basis van bedrijfsstijlen die waren gebaseerd op interviews of enquêtes in een regio. Deze aanpak is door Vanclay et al (1998) bekritiseerd vanwege het risico dat boeren eerst stereotypen formuleren over anderen, waarin ze zichzelf vervolgens niet meer herkennen. Ook zien zij een risico dat onderzoekers hun verwachtingen ten aanzien van categoriseringen bevestigd zien in de data (bias).

2 Burton and Wilson (2006) beschouwen de boeren en hun culturele normen als agency en het top-down beleid als structure, en merken op dat de culturele normen niet veranderen als gevolg van het top-down beleid. Zij duiden dit als een verschil in tempo tussen veranderingen op de niveaus van agency en structure. Wij gaan uit van culturele normen als structure, die slechts langzaam veranderen. 
In lijn met Burton and Wilson (2006) ziet Saunders (2016) in Zweden dat boeren ondanks jarenlang overheidsbeleid om multifunctionele landbouw te bevorderen (inclusief landschapsbeheer) een goede boer associëren met het zo efficiënt mogelijk produceren van voedsel en veevoer. Toch bleken boeren bereid om hun praktijken te veranderen als het boerenbedrijf daar in economische zin toekomstbestendiger van zou worden.

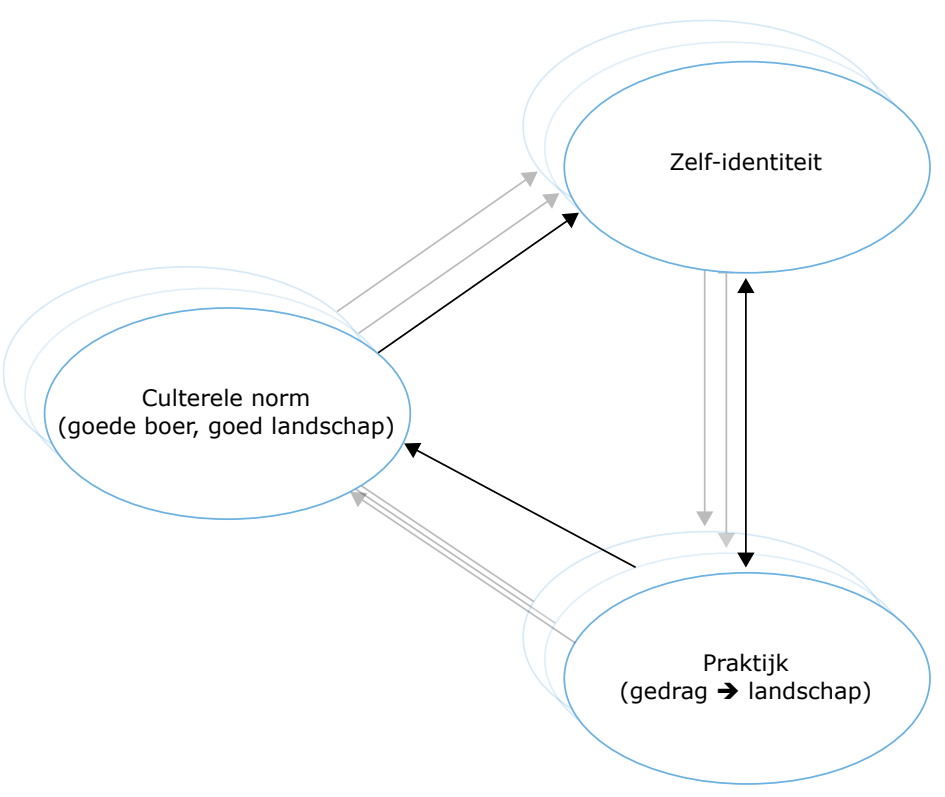

Figuur 2 Subculturen en geleidelijke verandering van culturele normen als gevolg van veranderende praktijken. Boeren kunnen bovendien wisselen van subcultuur. Gebaseerd op Van der Ploeg et al. (2009), Vanclay et al. (1998), Lokhorst et al. (2011) en Giddens (1984).

\subsection{Synthese en aanpak analyse}

Wij combineren deze theoretische inzichten als volgt:

Hoe boeren zichzelf zien als boer, en de culturele norm binnen de boerengemeenschap van wat een goede boer is, hebben grote invloed op beslissingen die boeren nemen ten aanzien van hun landgebruik. Er zijn subculturen binnen de boerengemeenschap met elk hun eigen culturele norm, die sterk samenhangt met de landbouwpraktijk. Boeren houden namelijk rekening met de culturele norm, omdat ze weten dat hun collega's hun land, erf en vee beoordelen. 'Goed land' is daarmee een van de zichtbare symbolen waarmee boeren hun vakmanschap kunnen tonen aan hun collega's en een middel om status te verwerven binnen de boerengemeenschap. Deze symbolen worden vooral geassocieerd met productiviteit en economische voorspoed, omdat landbouw ten eerste een manier is om in het levensonderhoud te voorzien. Daarmee is de beroepseer in relatie tot 'een net landschap' een mogelijke barrière voor de groei van natuurinclusieve landbouw. Toch is de culturele norm noch eenzijdig, noch onveranderlijk. Er zijn ook beelden van 'een goede boer' waar zorg voor bodem, milieu, landschap en biodiversiteit onderdeel van zijn. Wij gaan ervan uit dat natuurinclusieve landbouw een kans maakt als subculturen met een dergelijk beeld groter worden en als ook het productivistische beeld van een goede boer wordt verbreed. Daarvoor is het nodig dat natuurinclusieve praktijken van boeren zichtbaar worden gemaakt.

In het volgende hoofdstuk beschrijven we de casestudyresultaten. Daarin leggen we per casestudy verbanden tussen het beeld van een goede boer als zelfidentiteit, het beeld van een goede boer als culturele norm, het beeld 
van goed land, en natuurinclusieve landbouw. We hebben de respondenten gevraagd om zichzelf, een goede boer volgens de respondent, en wat over het algemeen in het gebied wordt gezien als een goede boer te beschrijven. Dit gaf de gelegenheid om te onderscheiden of iemand zich conformeert aan de culturele norm of zich er juist tegen afzet. Wat uiteindelijk per casestudy als culturele norm is samengevat, is gebaseerd op zowel individuele beschrijvingen van de goede boer en goed land, als op wat door de respondenten is beschreven als de culturele norm. Om een beeld te krijgen van de invloed van culturele normen in een casestudy op persoonlijke normen is gekeken naar uitspraken over onderlinge sociale controle (rondjes rijden), leren en samenwerken.

In hoofdstuk 4 stijgen we boven het niveau van de casestudy's uit en kijken we bovendien naar subculturen en verandering van culturele normen.

De theorie en de empirie van de casestudy's bieden diverse aanknopingspunten voor het beïnvloeden van het beeld van 'een goede boer'. Daar gaan we in 4.6 verder op in. 


\section{Casestudy's}

De casestudybeschrijvingen zijn interpretaties van de uitspraken van de respondenten. Het ging ons er niet om om hun uitspraken te verifiëren, maar om hun denkwereld beter te begrijpen.

\subsection{Midden-Limburg}

\subsubsection{Typering deelnemende boeren}

De respondenten in Midden-Limburg betreffen vijf mannen en een vrouw: twee grote melkveebedrijven, een groot akkerbouwbedrijf, twee gemengde bedrijven en een biologisch veebedrijf. De volgende typeringen intensief of extensief zijn van de respondenten zelf, evenals hun indeling in niveau van natuurinclusief. Drie van hen delen zich in in niveau 1, één in 1-2, één in 2 en één in 3 (zie Kader 1 op p.12). Eén van de respondenten was intensief en is extensief geworden; een ander heeft de omgekeerde ontwikkeling doorgemaakt. Hun strategische bedrijfskeuzes lopen uiteen: waar de één heeft geïnvesteerd in zowel grond als gebouwen, investeert een ander bewust in grond maar juist niet in gebouwen, nog weer een ander investeert in gebouwen maar niet in grond. Twee respondenten zijn twintigers, een dertiger, een veertiger en twee vijftigers.

Soms wordt in de gesprekken de relatie gelegd tussen houding ten opzichte van natuur en de leeftijd van de boeren. Volgens de een staan jonge boeren meer open voor ANLb (Agrarisch Natuur en Landschapsbeheer), omdat ze makkelijker meegaan met veranderingen. Volgens de ander staan oudere boeren juist meer open voor ANLb, omdat ze financieel onafhankelijker zijn. Volgens een jonge boer kun je je pas na een jaar of 30, als de meeste leningen zijn afbetaald, extensivering overwegen. De diverse sectoren in het gebied hebben invloed op elkaar: "Met akkerbouwers kun je niet concurreren om goede grond, dus ik heb mij altijd gericht op iets minder courante grond ook omdat we veel vee hadden om in de wei te laten grazen". Een ander ziet juist kansen in mestafzet bij en in grondruil met akkerbouwers.

\subsubsection{Goede boer}

\section{Zelfidentiteit en drijfveren}

De boeren in Midden-Limburg zijn onderling heel verschillend. Dat blijkt onder andere uit de woorden die ze gebruiken om zichzelf te beschrijven: koeienboer, natuurbeheerder in de dop, biologisch, ondernemer, cijfertjesboer, perfectionist, vernieuwend, anders dan andere boeren. Een van hen ziet boeren als een manier van leven. Vrijheid en autonomie vindt hij daarin heel belangrijk. Een ander noemt zich een echte ruwvoermelker: dat betekent dat hij goed let op de kwaliteit van het ruwvoer. Dat haalt hij dan ook zoveel mogelijk van eigen land, en het liefst zelf want met een loonwerker heb je de kwaliteit niet helemaal zelf in de hand. Zijn collega wil ook precies weten wat hij voert, en koopt daarom juist 'de prik' aan (verzelrijk voer). Twee van de veehouders noemen zichzelf vooral geen akkerbouwer. Volgens een van hen weten akkerbouwers meer van de bodem. Maar een andere veehouder probeert juist de bodemkwaliteit zo goed mogelijk op orde te krijgen. Er zijn verschillende soorten boeren: "Ik heb wat dat betreft altijd een voorkeur gehad voor dieren, ik ben nooit zo'n goede veldband, goede akkerbouwer geweest moet ik zeggen, heb ik ook nooit zoveel plezier in gehad. Ik heb ook geen binding met een mooie trekker of zoiets. Ik zit liever tussen de dieren." Ook natuurbeheer heeft te maken met wat voor boer je bent: "ANLb moet bij je passen".

De boeren leggen verschillende accenten in hun bedrijf. "Als je dan op biologisch gaat dan vraag ik me af, ik heb daar niet de overtuiging in dat ik dan met de koeien kan draaien zoals ik dat nu doe. Nee daar zit ook niet mijn motivatie want ik moet gewoon knallen er moeten gewoon liters in de tank en er moet inkomen zijn." Een ander spreekt over het geven van aandacht: "Goede resultaten halen op een fatsoenlijke manier, zonder grote mengvoerwagen, maar door goed op te letten, consequent te zijn, zes keer per dag het voer aan te schuiven, veel 
normale zaken eigenlijk die veel mensen vergeten." Het gaat om doelen halen en/ of om kosten beheersen. Voor melkveehouders is goed zorgen voor de dieren belangrijk: redeneren vanuit wat de koe nodig heeft, of "het maximale uit het beestje te halen zonder dat het ten koste van het beestje gaat".

De familie is belangrijk op de boerderij. De een wil het bedrijf van zijn ouders voortzetten, de ander wil het kunnen doorgeven: "Ik wil gewoon een boterham verdienen met datgene wat ik leuk vind en daar is het eigenlijk allemaal aan begonnen en ik hoop dat ik ooit het bedrijf kan doorgeven aan mijn zoontje." Een derde zegt: "Maar ik zit 's morgens ook met mijn kinderen aan het ontbijt, dat kan ook niet iedereen zeggen. En als ze uit school komen dan ben ik ook in de buurt (...). En dat vind ik ook een vorm van rijkdom". Desgevraagd is hij ten eerste trots op zijn kinderen. Trots zijn de boeren ook als ze resultaten zien van hun werk, of het nu gaat om de oogst, de melkafrekening of natuurresultaten zoals patrijzen. Ze kunnen genieten van bepaalde werkzaamheden zoals snoeien of op de trekker zitten, of juist de variatie in het werk, of van het zien van zwaluwen.

De boeren hebben ambitie en willen hun werk goed doen. "Je wilt vooruit". De jonge boerin wilde haar collega's "allemaal een poepie laten ruiken" om te bewijzen dat ze het kan. Diverse economische afwegingen spelen een rol. Uiteraard is een inkomen verdienen een belangrijke drijfveer voor de boeren, met name voor het gezin. Je moet aan je verplichtingen bij de bank kunnen voldoen. De boeren hechten belang aan zekerheid, stabiliteit, en onafhankelijkheid: "... en je bijvoorbeeld een wintervoorraad hebt liggen waar je de komende 12 maanden voldoende mee hebt dus gewoon de voldoening en de zekerheid die je onder het bedrijf hebt en dat daar eigenlijk weinig externe factoren daardoor zijn die je bedrijfsvoering beïnvloeden". Ook een natuurbeheervergoeding kan bijvoorbeeld een stabiel stukje inkomen zijn, en een goede oogst geeft rust. Extensiveren kan kostentechnisch slim zijn. Natuur is nadrukkelijk ook een economische activiteit. Het moet wel in te passen zijn qua arbeidsfilm (de manier waarop arbeid wordt ingezet in het bedrijf in relatie tot arbeidsbehoefte door de tijd heen - bijvoorbeeld pieken en dalen). En er is altijd de afweging of je de grond wel kunt missen.

Diverse boeren denken ook aan hun maatschappelijke omgeving. De een houdt met spuiten altijd rekening met wandelaars, door even te wachten tot ze op voldoende afstand zijn. Een ander maakt graag de combi met zorg, omdat mensen tot rust komen in de natuur. Iemand wil graag het dorp aankleden en mooier maken met zijn natuurbeheer. En weer een ander ziet dat koeien in de wei goed zijn voor het imago van de sector.

\section{Goede/slechte boer}

"Een goede boer is iemand die met oog voor de natuur en voor de mens en voor zichzelf toch een mooi gewas weet te telen eigenlijk". "Iemand die sterk is met zijn vak, weet wat hij doet en technisch ook heel goed weet hoe alles in elkaar steekt en hoe zijn bedrijf loopt. Iemand die zijn bedrijf van A tot Z kent, en niet alleen op stal maar ook de cijfers want zonder cijfers red je het vandaag niet meer." Verder zorgt een goede boer goed voor zijn of haar dieren, en levert een goed product af. Hij of zij weet de tijd goed te verdelen tussen werk en gezin, is een goede en vernieuwende ondernemer, en denkt goed na, ook over de toekomst. Een goede boer maakt het rekensommetje, heeft de zaakjes goed op orde en probeert ook wat te verdienen. Hij of zij verstaat het vak, zorgt voor voldoende organische stof in de bodem, stemt de bemesting af op het perceel, en heeft voldoende gewassen in rotatie. Een goede boer heeft passie voor zijn of haar werk en is gelukkig.

Een slechte boer is een slecht mens. Die maakt bijvoorbeeld zelf kalfjes dood, of levert VLOG-melk terwijl hij wel genetisch gemanipuleerde soja voert. Hij of zij houdt zich niet aan de regels, ploegt een halve meter te ver, is een knoeier, verwaarloost zijn/haar zaken, en straalt het vak niet goed uit. Een slechte boer pleegt roofbouw, is niet bewust met de bodem bezig. Een slechte boer is nooit klaar, heeft nergens tijd voor en ligt 's nachts wakker van de financiële zorgen. Uiteindelijk houdt een slechte boer het financieel niet vol en gaat failliet. Natuurlijk kunnen dingen tegenzitten. Je kunt een nieuwe stal hebben gezet en het toch niet rond krijgen. Iemands sociale gedrag zegt ook iets: als je niemand gedag zegt ben je ook geen goede boer. 


\section{Culturele norm in dit gebied}

Wanneer word je in dit gebied gerespecteerd door je collega's? "Ja, ik denk inderdaad wel als de akkers er strak bij liggen, als ze zien dat er groei in het bedrijf zit, als er nieuw materiaal over de weg rijdt. Dan is het, die doet het goed." Als iemand grond of fosfaatrechten heeft gekocht, wordt dat ook gezien als een uiting van economisch succes. Respect krijg je echter ook voor de manier waarop je je in het gebied gedraagt, en of je met iedereen een goede relatie kunt onderhouden.

De respondenten beschrijven de cultuur onder boeren in het gebied als dat er veel boeren in de weerstand zitten en bijvoorbeeld monologen afsteken tijdens bijeenkomsten; dat er teveel boeren leven om te werken en te kunnen blijven uitbreiden. Er zijn veel nieuwe stallen gebouwd en de financieringsdruk is vaak leidend in keuzes. Boeren vinden het lastig dat de regels steeds strenger worden. Maar de meesten willen gewoon een redelijke boterham en doen hun best om er iets moois van te maken. Het zijn vooral hardwerkende familiebedrijven met weinig personeel. Ze hebben duurzaamheid hoog in het vaandel, zorgen voor het landschap en proberen zo een steentje bij te dragen. Iemand schat dat $80-90 \%$ meedoet met ANLb, zowel voor de natuur als voor de vergoeding. Veel boeren hebben natuurgronden in gebruik. Er is best veel diversiteit in het gebied als het gaat om boeren. Je moet elkaar respecteren, inclusief de verschillen.

Sommige respondenten zien een verandering in de cultuur. Iemand ziet dat er minder gewasbeschermingsmiddelen worden gebruikt en verklaart dit uit de toegenomen kosten, maar ook uit de groeiende rol van het agrarisch collectief Natuurrijk Limburg. Een ander heeft het idee dat er meer door de uiterlijkheden heen wordt gekeken: waar een grote nieuwe stal vroeger respect afdwong, wordt nu eerder gedacht aan de waarschijnlijk hoge financieringslasten.

\section{Samenvatting}

Tussen wat boeren over zichzelf zeggen en wat ze een goede boer vinden, zit een duidelijke relatie. Een 'koeienboer' zorgt goed voor de dieren en/of heeft veel aandacht voor de kwaliteit van het voer, een 'ondernemer' vindt ondernemerschap belangrijk, en een hoogproductieve boer vindt dat je moet 'durven bemesten'. Volgens de veehouders zijn de akkerbouwers meer met land en bodem bezig dan zij: "Ik ben een koeienboer, ik heb niks met machines heb weinig interesse in landwerk."

Een deel van de respondenten zet zich af tegen de culturele norm van nieuwe stallen en trekkers en leven om te werken: zelf zitten ze niet zo in elkaar. Een deel identificeert zich juist met de andere boeren: "De melkveehouders in deze regio lijken veel op elkaar, ik denk dat we hier redelijk op 1 lijn zitten."

\subsubsection{Goed land}

Goed land heeft een mooi schoon gewas, egaal en gezond. Goed land heeft in iedere ploegvoor een oogstbaar gewas: land moet opbrengen. Afwisseling tussen gewassen kan ook mooi zijn. Het moet er wel netjes uitzien, goed bijgehouden en verzorgd. Goed land heeft goede, vruchtbare grond. Het gras is mooi groen en kort, het is een zuivere weide zonder onkruid, anders kun je niet presteren met je koeien. Er lopen gezonde, verzorgde koeien in de wei. Slecht land is een rommeltje. Er staat veel onkruid, is bijvoorbeeld volgelopen met distels of melde. Ook boeren die aan ANLb doen, kunnen zich daar zorgen over maken. Slecht land brengt niets op. Het is te nat, in de schaduw, of een lastig bewerkbare hoek. Die kun je missen voor natuur. Zo kun je de minder courante plekken toch tot waarde brengen.

De respondenten denken echter niet meer alleen in voedselproductie. Wat goed land is, hangt af van het doel. Strak gras en een veldje met spelt en insecten en vogels: het kan allebei mooi zijn. Goed land kan ook een patrijzenrand zijn met zonnebloemen. Een van de respondenten was blij om de waardplant van de 'Blauwe Pimpernel' te vinden op zijn land, omdat dat de bedoeling was. De respondenten kunnen ook genieten van bloemetjes en bijtjes. Het hoeft allemaal niet meer zo steriel volgens een van hen: natuurlijke vijanden moeten ook een kans krijgen. 
Twee respondenten geven aan dat ze anders tegen land aan zijn gaan kijken: "Je gaat een andere bril kopen eigenlijk, dus het is dan ook wel heel mooi zoals afgelopen zomer die hele patrijzenrand in bloei te zien met de zonnebloemen en alles, en dan ook echt op patrijzen te letten." "Kijk en vroeger zag je een perceel en dan denk je daar kan ik mooi uien op telen. En nu zie je een perceel en dan koop je dat omdat je er een mooie paddenpoel en struweeltje en dat soort dingen op kan aanleggen."

Bij extreem weer kun je aan de gewassen zien wie de betere en wie de slechtere boeren zijn. Echte akkerbouwers houden hun land goed bij. Boeren beoordelen elkaar dus op basis van de kwaliteit van hun land, maar wat je ziet heeft ook veel met je kennis te maken: "We hebben bijvoorbeeld een man hier in de buurt die heeft meer agrarisch natuurbeheer nog dan normale akkers als ik het zo zou zeggen, en ik weet dan wat hij doet met die haagjes planten allemaal langs de weg, het is herkenbaar wat je ziet. Maar als jij niets van agrarisch natuurbeheer afweet, dan is het een rommeleer, rotzooimaker. Het is denk ik, de scheidslijn is echt wie weet er wat van en wie weet er niets van. Wie er wel iets van weet die zegt, slimme vogel, daar verdient hij meer mee dan met die magere bieten vorig jaar."

\subsubsection{De invloed van culturele normen}

\section{Rondjes rijden en daar rekening mee houden}

Als Midden-Limburgse boeren door de omgeving rijden, kijken ze naar het land van hun collega's en vergelijken ze dat met hun eigen land. "Ik vind het ook wel mooi een vergelijking te maken als je hetzelfde gewas hebt. Als je suikerbieten hebt, dan zie je hoe die gerooid worden, welke water hebben gehad dat weet je. Je rijdt altijd rond dus je weet wie hoe vaak heeft gehaspeld. Als die gerooid worden rijd je wel even extra rond en dan kijk je." "Ik ben in ieder geval tevreden als ik door het veld rij en ik zie mijn eigen percelen staan dus ten opzichte van de buren en alles wat in de regio staat denk ik dat we wel bovengemiddeld meedraaien. Misschien nog wel ruim bovengemiddeld maar dat is mijn mening. Maar ik weet niet hoe anderen daar naar kijken. Ze kunnen in ieder geval niet zeggen ze zijn een prutser dat weet ik zeker." Boeren kijken naar het gewas, het vee, werkzaamheden, de oogst, nieuw gekocht land. Aan het land kun je niet de financiële situatie zien, maar wel de aard van de ondernemer. Een van de respondenten kijkt ook op de website van het kadaster om te zien wie grond heeft gekocht en hoeveel hypotheek erop zit.

De boeren weten dat de buren ook rondjes rijden. Boeren zullen elkaar echter niet aanspreken op hoe het land erbij ligt. Sommigen zijn ervan overtuigd dat ze een goede reputatie hebben: "En in het algemeen staan wij er wel om bekend dat wij het allemaal netjes voor elkaar, opgeruimd en fatsoenlijk erbij ligt. Zo wordt dat wel gezien." Een ander gaat ervanuit dat collega's zijn natuurbeheer een rotzooitje vinden. De respondenten zeggen niet of nauwelijks rekening te houden met de mening van collega's bij hun keuzes. Ze maken zich daar geen zorgen (meer) over of laten zich daar niet door leiden. Een van hen probeert wel de onkruiddruk vanuit zijn natuurbeheer te beperken met het oog op het land van de buren.

\section{Cultuur van samenwerking}

Volgens een van de respondenten doen boeren in dit gebied niet graag dingen samen. Ze zijn allereerst elkaars concurrenten, ook met ANLb. Anderen zien het ANLb juist als voorbeeld van samenwerking: steeds meer boeren doen mee. Andere voorbeelden van samenwerking tussen boeren zijn dat buren elkaar soms helpen met werkzaamheden en dat grondruil plaats vindt tussen akkerbouwers en veehouders. Iemand heeft zijn jongvee en droge koeien bij collega's in de buurt staan vanwege de fosfaatrechten. Volgens een van de respondenten is de boerenmanier van samenwerken: eerst informeel, dan pas formeel. Het moet niet te snel juridisch worden. De melkveehouder die graag liters maakt, is actief in een Patrijzenwerkgroep: "Nu is dat project en dan denk je van och ja verrek, zo is dat wel, er zijn er veel minder. En ja dan ga je er over denken en dan kom je met zo'n groepje bij elkaar en ja, dan ga je er mee aan de slag. En je merkt wel nu ook met de eerste tellingen: het heeft wel zin. En dan doe je het ook niet voor niks. Ik wil zeggen het is ook mooi." 


\section{Gespreksonderwerpen}

Boeren in het gebied spreken onderling niet gemakkelijk over zorgen: "ze hebben wel hun hoofd recht te houden". Meer oppervlakkige problemen komen wel aan bod: mest, vee, grond, het weer. Ze wisselen uit over gewassen en prijzen. Bij Natuurrijk Limburg spreken ze ook met elkaar over aantallen kieviten en patrijzen. Een van de respondenten verklaart het gebrek aan gesprek en uitwisseling tussen collega's aan de diversiteit tussen bedrijven en de hoge specialisatiegraad: collega's hebben nog weinig met elkaar gemeen.

\section{Hoe boeren leren}

De respondenten leren van de vorige generatie, van contact met specifieke collega's, van dingen zien van anderen (bijvoorbeeld een patrijzenrand). Soms gaat dat bijna per ongeluk. Een respondent zegt over niet-kerende grondbewerking: "Dus het kan goed, alleen ik ben er niet bewust mee bezig van het moet allemaal zo. Het komt meer op je pad en je ziet het van anderen en dan denk je van och ja laten wij dat ook eens proberen." Een van de respondenten doet zelf advieswerk en leert daardoor ook veel van de bedrijven waar hij komt.

Een van de respondenten maakt deel uit van een studiegroep die de jaarcijfers vergelijkt. Dit zijn nadrukkelijk geen boeren uit de buurt. Ook tussen collega's die aan ANLb doen, wordt uitgewisseld door middel van kijken en vergelijken. Samen door het perceel lopen is daarvoor heel geschikt. Vanuit de medewerkers van het collectief vindt kennisoverdracht plaats: "Onze gebiedsmentor van het collectief die begeleidt dat heel goed. Die houdt dat in de gaten, die bekijkt dat, die overlegt, die spreekt je daarop aan". Daarnaast wordt geleerd op bijeenkomsten over het ANLb. Het collectief Natuurrijk Limburg heeft weer kennis over patrijzenbeheer uit Brabant gehaald.

De boeren leren ook door zelf dingen uit te proberen en door bijvoorbeeld ervaring op te doen met natuurpakketten of te "oefenen" met een patrijzenrand. Door mee te doen met een project over patrijzen ga je er over nadenken (zie citaat bij cultuur van samenwerking).

De respondenten leren ook van gegevens en van analyses. Bodemanalyses kunnen bijvoorbeeld nuttige informatie opleveren. Gegevens over welke soorten er zitten en tellingen geven boeren feedback op hun natuurbeheer: "Ik heb het opgeschreven, we hebben 15 soorten en dan kun dat thuis nog eens opzoeken op internet. Leer je ze zelf ook een keer kennen. Het zijn vaak van die kleintjes, akkerogentroost en ik weet niet."

\subsubsection{Natuurinclusieve landbouw}

\section{Wat ze nu al doen}

De respondenten doen allemaal aan een vorm van ANLb. Patrijzenakkers en -randen zijn populair, soms met keverbanken, en er zijn respondenten met een steenuilenkast, pakketten voor hoogstamboomgaarden of botanische akkerpakketten. Een respondent doet "bijna alle pakketten die mogelijk zijn". Deze boer heeft "landbouw eigenlijk gewoon als bijzaak bij de natuur" en zet in op rode lijstsoorten zoals kamsalamander en boomkikker om in de toekomst ook nog inkomsten uit natuurbeheer te kunnen krijgen. Twee respondenten vinden het logisch om in dit afwisselende, kleinschalige landschap aan ANLb te doen: "je hebt een hoekje van een perceel of het is zo'n klein perceel of het is voor het huis het ziet er mooi uit je probeert er iets van te maken dan zie je toch dat je stiekem wel wat zaken doet ook voor agrarisch natuurbeheer."

Naast ANLb beheren meerdere respondenten natuurgraslanden van terreinbeherende organisaties door beweiden en/of maaien. Natuurhooi kan bijvoorbeeld aan het jongvee worden gevoerd. Dat gaat soms wel met gemengde gevoelens: "Ik vind het goed dat er iets gedaan wordt voor de natuur, maar natuur maken met een graafmachine heb ik nooit gesnapt. De goede vruchtbare grond wat er door de natuur gekomen is om die weg te halen om er weer iets om zo maar zeggen duizend jaar terug in de tijd te gaan. Nee, dat zie ik niet zitten en dat vind ik gewoon verkwanselen van gemeenschapsgeld".

Ook zijn respondenten bezig met natuurlijke vijanden, het stimuleren van bodemleven, en met kringlopen. "Als je in de natuur doet, komen dat soort dingen automatisch mee". Een van hen is aan het experimenteren met niet- 
kerende grondbewerking. Hij voert ook perspulp van de suikerfabriek en bierbostel en noemt dat 'kringloopproducten'. Verder stuurt hij op goede kwaliteit kuilen zodat hij minder krachtvoer nodig heeft. Ook de biologische boer werkt 'vanzelfsprekend' aan het sluiten van kringlopen. Een van de respondenten geeft aan niet te spuiten met glyfosaat.

De respondenten staan positief tegenover het idee van natuurinclusieve landbouw: "ik zeg altijd we zijn in natuurinclusieve landbouw want zonder natuur gaat het ook niet". Landbouw en natuur kunnen elkaar versterken. Het gaat meer die kant op. Een van hen verwacht zelfs dat "gewone natuur, zoals een bloemetje en een bijtje", in de toekomst niet meer wordt vergoed. Een ander vindt echter dat het niet te ver moet gaan met natuurbeheer op het bedrijf: als er geen opbrengst vanaf komt, is het geen natuurinclusieve landbouw meer.

De respondenten schalen zichzelf in als natuurinclusieve landbouw niveau 1, 2 of 3 . Vier van hen willen best nog meer doen.

\section{Wat helpt om meer te doen}

De respondenten zijn het erover eens dat een goede vergoeding helpt om meer aan natuurinclusieve landbouw te doen. Dat is nodig voor het verdienmodel: er moet wel een boterham kunnen worden verdiend. Er zit echter ook een wens achter van wederkerigheid: de boeren leveren een dienst aan de maatschappij en daar mag best iets tegenover staan. Bij de overheid is bewustwording nodig dat het niet voor niets kan. Maar er wordt niet alleen naar de overheid gekeken. Het beetje meer melkgeld via Foqus Planet van FrieslandCampina wordt door een van de boeren als een goede stimulans gezien. En de consument heeft ook een rol: het zou mooi zijn als fruit van klasse 2 en 3 weer verkocht zou kunnen worden in de supermarkt.

Over regelgeving zijn de respondenten het niet eens. De een vindt dat natuurinclusieve landbouw vooral niet moet worden opgelegd, een ander vindt dat verplichtingen het juist makkelijker kunnen maken. Weer iemand anders vindt dat er in Europa voor een gelijk speelveld moet worden gezorgd. Het is frustrerend als de goede bedrijven meer worden gecontroleerd dan de slechte. En een zekere flexibiliteit zou helpen, met name in relatie tot maaidata en het weer. Ook zou er iets gedaan moeten worden aan predatoren, al is het logisch dat die in dit landschap zitten.

Met meer grond kun je meer doen. Een stukje kennis helpt ook. Het moet aansluiten bij de bedrijfsvoering, in de puzzel passen. Dat is voor de een gemakkelijker dan voor de ander: "En er moeten gewoon euro's gemaakt worden. En euro's kan alleen maar door hoeveelheid. En ik moet gewoon zoveel mogelijk melken om mijn bedrijf draaiende te houden. En dat is misschien het alom bekende verhaal van: we zitten in een bepaalde richting waar je niet uit kan." Tegelijkertijd wordt erkend dat alleen maar intensief telen op den duur niet meer zal gaan. De boeren hebben tijd nodig en begeleiding om om te turnen.

\section{Kan natuurinclusief deel uitmaken van goede landbouw?}

De casestudy Midden-Limburg levert diverse aanknopingspunten op waarom en hoe natuurinclusief deel kan uitmaken van goede landbouw. Het landschap zelf biedt al een geschikte uitgangspositie: "Het is sowieso al een divers gebied zeker omdat we kleinschalig zijn dus een monocultuur kun je bij ons niet vinden omdat het gebied zelf al heel divers is." Boeren in dit gebied hebben verbinding met het landschap en de respondenten hebben zorg om natuur en genieten er ook van.

Hoewel minder sterk dan in sommige andere casestudy's in dit onderzoek, zien de boeren ook voordelen van natuur voor hun eigen bedrijf, met name in de vorm van bodemleven, natuurlijke vijanden, het winnen van natuurhooi en een goede combi met zorglandbouw. Onkruid ligt gevoelig, maar minder dan voorheen. Natuur kan een doel of functie zijn naast productie: op die manier kan een veld met veel bloemen ook goed land zijn. Daarmee kun je ook met natuur op je bedrijf een goede boer zijn. Ook vanuit het oogpunt van ondernemerschap: als je het rekensommetje maakt, is het slim om met ANLb mee te doen. In de focusgroep is letterlijk samen een sommetje gemaakt. 
Een ander aanknopingspunt is het imago van de sector en het bedrijf. Boeren zijn daarmee bezig, ze zien de vraag vanuit de maatschappij veranderen, ze trekken zich de publieke opinie aan. Voor de toekomstbestendigheid van het bedrijf is het zaak om daarin mee te bewegen.

In dit gebied is er waardering voor diversiteit tussen boeren. Natuurinclusief kan zich wellicht ontwikkelen tot 'ook een soort goede landbouw'. Dan kan zich een subcultuur ontwikkelen waarin met de natuur werken vanzelfsprekend is: "Nou, goed ik ben biologisch dus ik dacht al wat anders dan de gangbare denk ik. Dus." Andere boeren benoemen zelf dat ze anders zijn gaan kijken nu ze er meer van weten. Het helpen ontwikkelen van kennis, en vakmanschap ontwikkelen met betrekking tot natuur op het bedrijf is dan ook een kans. Het agrarisch collectief lijkt daarvoor een succesvolle aanpak te hebben. Ook pikken boeren dingen op bij elkaar.

Tot slot kent deze casestudy een aantal boeren waarvan je misschien niet direct zou verwachten dat ze zoveel natuurinclusieve dingen doen, omdat ze zo groot en intensief zijn of waren. Stereotyperingen zijn dus niet altijd behulpzaam. Aan de andere kant zegt een intensieve melkveehouder: "Kringlooplandbouw kan niet als alles natuurinclusief is, want wat is dan kringloop? Je kan van je eigen grond niet veel af halen. Als je pech hebt moet je veel aankopen." Daarmee lijkt hij te suggereren dat intensieve bedrijven niet zowel aan kringlooplandbouw als aan natuurinclusieve landbouw kunnen doen.

\subsection{Noord-Beveland}

\subsubsection{Typering deelnemende boeren}

De respondenten in Noord-Beveland betreffen zes akkerbouwbedrijven, waarvan één bedrijf als groot is aan te merken (>100 ha), vier bedrijven als middelgroot (gemiddeld 60 ha) en één bedrijf als klein ( $<15$ ha), dit gaat om een groenteteler. Geen van de boeren heeft een biologisch akkerbouwbedrijf of heeft de intentie om hier naartoe over te schakelen. In 2015 waren er 103 agrarische bedrijven op Noord-Beveland waarvan er één bedrijf biologisch is (CBS, 2015). Wel laat één van de zes akkerbouwondernemers zich regelmatig inspireren door het gedachtegoed dat tot de biologische akkerbouw behoort en past hier ook aspecten van toe in zijn eigen bedrijfsvoering. De respondenten typeren zichzelf als extensieve boeren en delen zichzelf voornamelijk in op het niveau 1 van natuurinclusief boeren (zie Kader 1 op p.12). Eén combineert 0 met 2 en één twijfelt tussen 1 en 2 . Extensief betekent voor de respondenten een ruime gewasrotatie: een gewas laten rouleren om de vijf of zes jaar noemen zij extensief. Een gewas om de 3 of 4 jaar laten rouleren noemen zij intensief. De respondenten verwijzen met extensief en intensief daarmee niet naar gewaskeuze. Peen, uien en pootaardappelen worden bijvoorbeeld doorgaans als intensieve gewassen beschouwd, vanuit het perspectief van bodembeheer en arbeid.

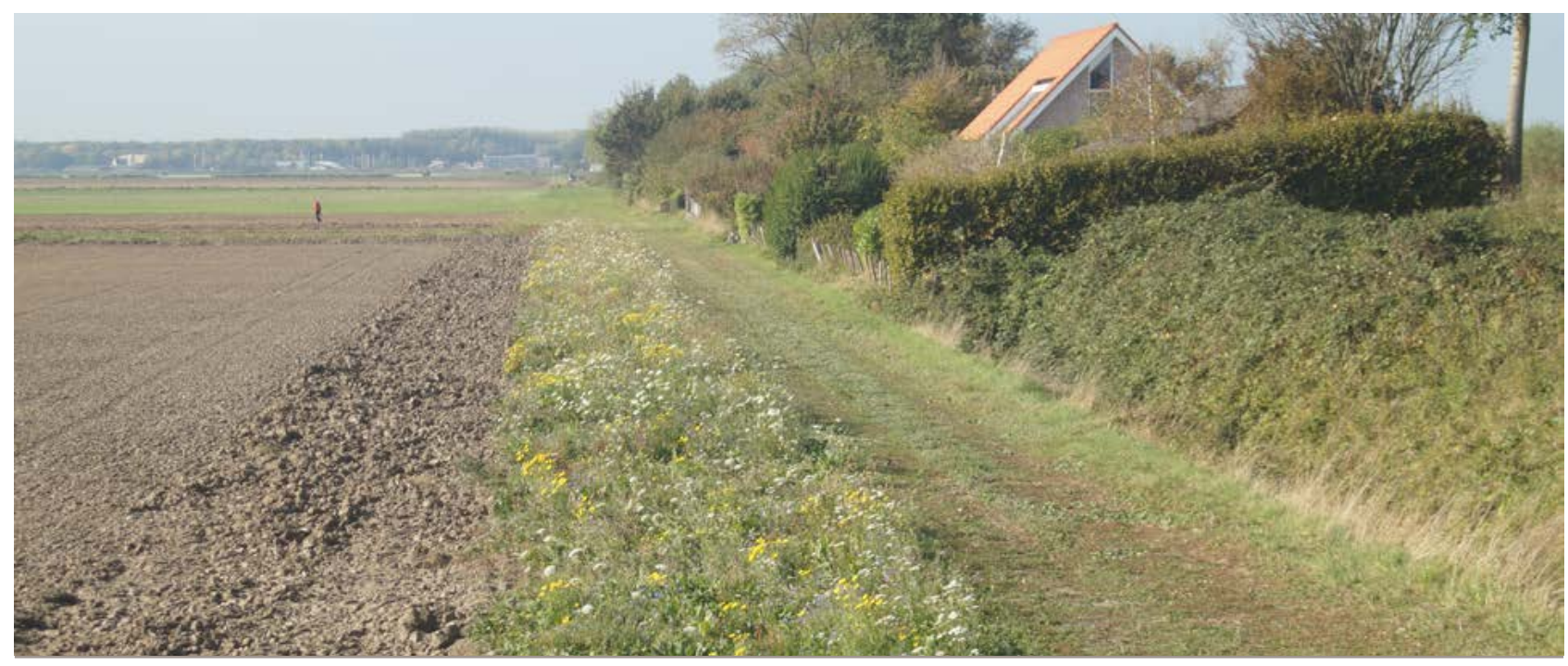


De groep bestaat uit vier dertigers en twee zestigers. Alle boeren geven aan dat ze vroeger intensiever boerden en extensiever zijn geworden. Eén van de boeren overweegt om in de toekomst weer wat intensiever te gaan boeren. De twee oudere boeren relateren het extensiever boeren aan de in de tijd groeiende openheid en waardering voor natuur. Twee jongere boeren benadrukken dat zij een open houding hebben voor innovaties en specialisaties. Eén van de respondenten schetst het toekomstperspectief voor akkerbouwers in Noord-Beveland als volgt: "of heel groot, of heel klein en gedifferentieerd: geen standaardteelten." De vier jongere boeren hebben allen zelf een nevenbaan. De groenteteler heeft ook een winkel.

\subsubsection{Goede boer}

\section{Zelfidentiteit en drijfveren}

De respondenten in Noord-Beveland zijn niet heel verschillend. De woorden waarmee zij zichzelf omschrijven, verwijzen naar de bodem, milieu- en natuurvriendelijk boeren en vooral ook naar teeltopbrengsten en financiële opbrengsten. De boeren in Noord-Beveland relateren allen hun zelfidentiteit en drijfveren daarmee zowel aan economische als aan ecologische aspecten. Eén van de boeren legt ook een nadruk op het sociale aspect. De respondenten omschrijven zichzelf op verschillende wijze: specialisatie- en opbrengstboer, teelt- en opbrengstboer, boer met interesse voor gemengd bedrijf vanuit kringlooplandbouwgedachte, stoppende boer met oog voor milieu, natuur en landschap, kleinschalige specialisatieboer met oog voor milieu, natuur, landschap en recreatiebeleving en een sociaal ondernemende boer. De specialisatie- en opbrengstboer vindt een goede boer een slimme boer met uniek gewas (bijvoorbeeld teunisbloemen) en stabiele inkomstenbron (bijvoorbeeld pootaardappelen), goede keuzes maken op basis van vakmanschap, onafhankelijkheid (niet leasen of lenen bij de bank).

De teelt- en opbrengstboer gaat vooral voor bovengemiddelde opbrengsten in de regio. De boer met interesse voor een gemengd bedrijf vanuit de kringlooplandbouwgedachte geeft aan dat een goede boer de boer is die de bodem ontziet met gewasrotatie: "grond is je prioriteit, de kostprijs mag hoger liggen om bodemvruchtbaarheid in stand te houden: dus veel compost, vaste mest, groenbemesters naast kunstmest, echt extensief met een high input van organische mest, bewust bezig zijn met betrekking tot natuur." De stoppende boer met oog voor milieu, natuur en landschap verwoordt het zo: "Je probeert het voor jezelf zo goed mogelijk te doen (...) en: ik boer ongeveer hetzelfde als mijn collega's (...). Duurzaam bodembeheer moet je gewoon doen." En: "Een mooie oogst, dat is dankzij dat je op een goede manier bezig bent op je land."

Een kleinschalige specialisatieboer met oog voor milieu, natuur, landschap en recreatiebeleving omschrijft zichzelf als volgt: "Ik ben meer een boer die in milieu, natuur en toerisme zit dan een boer die alleen voor de winst gaat. Ik zoek het in het bestrijden met selectieve middelen, oogstpaden om de bodem niet kapot te rijden."

Een sociaal ondernemende boer valt op omdat hij in zijn omschrijving aangeeft dat hij in een VOF (vennootschap onder firma) samenwerkt met andere bedrijven op alle aspecten van bedrijfsvoering en deelneemt omwille van het sociale element, samen de werkverdeling, inkoop en verkoop besprekingen doen: "op een gegeven moment had ik geen lol meer in mijn werk. Nu ben ik met een club. Je kunt veel meer aanpakken, je bent slagvaardiger en je hebt gewoon meer plezier in je werk. Er zijn mensen die meer specialiteit en kennis op bepaalde vlakken hebben en dat is gewoon prettig om daarmee samen te werken."

Uiteindelijk geven de boeren ook aan met hun beschrijvingen van hun zelfidentiteit hoe ver ze bereid zijn om te gaan met milieu- en natuurgerichte maatregelen en dat neigt niet naar biologische landbouw: "Helemaal niet meer spuiten en het gewas verliezen zou indruisen tegen mijn boer zijn." En "Ik probeer zo milieu- en natuurvriendelijk mogelijk te boeren; maar aan een aantal bespuitingen ontkom je echt niet." Wel is in de focusgroep benadrukt dat vandaag de dag natuurvriendelijkere middelen worden ingezet ook al zijn deze wel duurder. De boeren leggen wel verschillende accenten in hun bedrijf als het gaat om bodemverdichting, bodemvruchtbaarheid, extensivering, natuur en milieu en de wijze waarop opbrengsten tot stand komen. 
De drijfveren van de respondenten in Noord-Beveland zijn talrijk: zelfstandigheid, vrijheid, mooi wonen en mooi uitzicht, genieten van de natuur, het hele landbouwproces van voorbereiding en zaaien tot oogsten en verkoop als vrucht op de arbeid, het werken met machines, natuur en weersomstandigheden als werk, hobby en passie. Opvallend zijn de volgende citaten: "Ik wil het bedrijf doorgeven aan de volgende generatie met een goede bodem." Drijfveren om aan bloemenranden te doen zijn dat ze het mooi vinden, er weinig kosten mee gemoeid zijn, en ze er een goede vergoeding voor krijgen. Eén van de twee oudere boeren hierover: "Ik doe graag mee met de bloemranden. Ik vind dat mooi. En het is een mooie vergoeding. Er zitten weinig kosten aan; je hoeft weinig te doen. Maar voor een te lage vergoeding doe je het niet." En de andere oudere boer: "We proberen echt wat van die randen te maken. Het is gewoon leuk. Er is hier echt een opleving van fazanten, bijen en vlinders en noem maar op. Het is ook beleving. Ik vind dat gewoon mooi. Met een bloemenrand heb je ook minder emissies naar sloten." De twee oudere boeren geven aan dat zij natuur steeds leuker zijn gaan vinden: "Ik zou ook nooit weggaan hier om ergens anders te kunnen boeren. Ik zie in mijn omgeving dat ik dat (natuurinclusieve landbouw) gewoon mooier vind als dat ik ooit gedacht heb. Dat ik het toch allemaal leuk vind, mooie akkerranden en je ziet gewoon veel meer natuur en ik sta daar veel meer voor open dan 10 tot 15 jaar geleden."

Twee van de vier jongere boeren laten zich vooral door de economische kant van het bedrijf leiden: "extra kosten moeten ook extra opbrengsten opleveren (en besparingen mag niet te veel opbrengst kosten)" en "ik ben milieubewuster doordat je meegaat met de ontwikkelingen" (je doet het er niet per se om). "Ik wil best iets voor natuur doen, maar dan moet je wel direct resultaat zien" (in relatie tot doelen en haalbaarheid).

De twee andere jonge boeren benadrukken wel de beperkte arbeid en kosten, de opbrengst, de schoonheid en een ander type werkhouding als drijfveren: "Akkerranden, daar steek je weinig tijd in en het levert wat op. Ik hoef de hoofdprijs niet, maar de economische rekensom moet kloppen. Prachtig alle beestjes in de akkerrand." En: "Ik heb liever een klein bedrijf met meer takken van sport. Dat is leuker dan jaarrond hetzelfde werk. Ik werk liever met de natuur dan tegen de natuur (...). Ik probeer een paar jaar consequent te zijn met een natuurvriendelijke methode om natuurlijke vijanden te krijgen."

\section{Goede/slechte boer}

De boeren geven de volgende omschrijvingen van een goede boer: "Een goede boer is een boer die de buren wil helpen. Aan de grond denkt en er voor zorgt, niet te intensief; ruimte gewasrotatie." Een andere boer: "Een goede boer is iemand die zorg heeft voor zijn gewassen en daarmee voor de bodem." Weer een andere boer: "Een goede boer is iemand met fantastische gewassen en zonder water op het land en hoeft niet eens een goede koopman te zijn." Tijdens de focusgroep was hier ook een discussie over. Een boer dient een goede teler en een goede verkoper tegelijk te zijn. Als een boer een goede verkoper is, kan de druk verminderen om tot het uiterste te gaan voor een hoge gewasopbrengst. Een boer verwoordt dat dit sowieso de houding dient te zijn: "Een goede boer draait rendement zonder zijn land uit te putten. Hij biedt stabiliteit en zorgt voor de volgende generatie, is een rentmeester." Een andere boer sluit hier met zijn omschrijving van een goede boer op aan: "Een goede boer haalt met beperkte mogelijkheden toch een goed inkomen met milieu en natuur in het achterhoofd. Een goede boer houdt de bodem gezond en past de juiste machines toe." Weer een andere boer sluit ook aan bij dit gedachtegoed en verwoordt het zo: "Een goede boer teelt de juiste gewassen met zorg voor de omgeving en doet iets om van de natuurlijke vijanden te profiteren." En een andere boer in gelijke woorden: "Een goede boer werkt netjes, laat het bedrijf goed economisch draaien en heeft oog voor de omgeving." Tot slot benadrukt ook nog een andere boer de omgevingsgerichtheid: "Een goede boer is iemand waar de rook tegen de wind in gaat. Dus daar zijn er niet zo veel van. Omgevingsbeleving naar je omgeving toe hoort er ook bij. Hoe je in de omgeving staat, niet alleen maar met jezelf bezig zijn op een eiland als dit."

De boeren geven bij de omschrijvingen van een slechte boer aan dat zij hierbij naar zowel opbrengst kijken als naar belasting van bodem, milieu, natuur en landschap: "Een slechte boer kan een goede teler zijn maar een slechte verkoper" en "Een slechte boer is een boer die er niks mee verdient en die heel intensief werkt met zware milieubelasting." Opvallend is dat onkruid genoemd wordt als voorbeeld van slecht boeren in de onderstaande 
citaten: "Een slechte boer is een boer die weinig marge overhoudt, intensief gewassen gebruikt die de bodem uitputten en die hoge investeringen doen, die een veld vol onkruid hebben staan." Een andere boer: "Een slechte boer is een boer met slecht land: meer onkruid dan gewas, verlopen of verdroogd gewas, dun of ontbrekend gewas op plekken." Deze boer betrekt het op het veronachtzamen van bodembeheer: "Een slechte boer is een boer die alleen denkt aan korte termijn cashen. Komen en het land en de bodem leeghalen. Na mij de zondvloed." Weer een andere boer vindt dat het land goed benut moet worden: "Een slechte boer is iemand die niet het potentieel van zijn land goed benut" (niet te intensief, maar ook niet uit gemakzucht te extensief: te veel laten). Er is ook een boer die een slechte boer koppelt aan het maximale grondgebruik voor voedselproductie: "Een slechte boer is een boer die puur voor de winst gaat, tot op de laatste vierkante $\mathrm{cm}$, heel intensief tot aan de rand rijden, liefst nog in de sloot spuiten en alles kort maaien. Je ziet wel eens overhoekjes vol 'meebeboerd' worden." Met overhoekjes wordt gedoeld op een stuk land op een perceel wat minder geschikt is voor de voedselproductie én vaak zeer geschikt is voor de natuur. Er zijn agrariërs die ook op stukken land die minder gunstig zijn voor gewassen (bijvoorbeeld omdat ze te nat zijn en de grondbewerking bemoeilijken in vergelijking met de overige delen van het perceel) toch gewassen verbouwen en hier bijvoorbeeld niet de voorkeur geven aan inrichting met heggen of bloemranden. Weer een andere boer koppelt een slechte boer aan de netheid van het bedrijf: "Een slechte boer is een boer de die de zaak laat versloffen: bedrijfstechnisch, geen zorg voor het gewas, voor de omgeving. Op hun percelen vindt een slijtageslag plaats. Dat zie je gewoon. Daar wordt het onderste uit de kan gehaald."

\section{Culturele norm in dit gebied}

Wat is de norm vanuit collega's in dit gebied om gerespecteerd te worden? De meeste akkerbouwers in NoordBeveland produceren voor de bulk, de wereldmarkt. De akkerbouwers willen niet het maximale eruit halen, niet vol gas gaan en elke millimeter benutten, anderzijds willen zij wel zo goed mogelijk de potentie benutten die het land biedt om een zo hoog mogelijke en kwalitatief goede voedselproductie te bereiken. Een boer wil ook niet het gevoel hebben dat hij geld laat liggen. Bodemverdichting leeft niet zo, onder water zetten van land tegen bodemziekten is onbespreekbaar. Goed voor je land zorgen, mooie producten, het inschakelen van lokale loonwerkers en het bezoeken van lokale bijeenkomsten zorgen voor acceptatie. Als boer wordt je geaccepteerd door niet te oordelen over een ander, door gewoon sociaal open te staan voor anderen.

De norm lijkt bepaald te worden door bedrijven die groeien en resultaten laten zien. Het aanzien van een boer kan worden bepaald door hectares en het bijbehorende machinepark (materialisme). Er is volgens de respondenten een kentering op komst met betrekking tot de houding ten aanzien van natuur, dat komt volgens hen ook tot uitdrukking in de voorlichting. Boeren krijgen meer interesse in natuurlijke vijanden: "Tien jaar geleden zou je zijn uitgelachen om natuurlijke vijanden." En een andere respondent: "Het verandert van standaard bespuiten naar monitoren en dan pas gericht spuiten. Het ouderwetse denken is alles preventief elimineren wat je tegenkomt: aaltjes zijn slecht, gelijk stomen of ontsmetten, doodmaken. Nu realiseren we dat daarmee ook het goede bodemleven kapot wordt gemaakt. Het korte termijn cashen wordt minder op Noord-Beveland." En weer een andere boer ziet extensieve gewasrotatie als een goed voorbeeld: "Iedere boer moet zelf voor zijn bedrijf zorgen, de een heeft wel geld over voor duurzaam bodembeheer en de ander niet. Ik denk dat wij tot de uitzonderingen behoren die zo extensief boeren" (bouwplan met een gewasrotatie van 1 gewas op 6 jaar).

\section{Samenvatting}

Er zijn veel overeenkomsten tussen het zelfbeeld van de boeren en wat ze een goede boer vinden. Naast een goede teelt en teeltopbrengst worden duurzaam bodembeheer en akkerranden veelvuldig genoemd. Omtrent onkruid is wel een verschil in opvatting waarneembaar: de één ziet dit als niet netjes, de ander als een mogelijke habitat voor natuurlijke vijanden die boeren kunnen helpen. De culturele norm lijkt nog gericht op teelt en bestrijden van ziekten en plagen met gewasbeschermingsmiddelen. Er zijn twee respondenten die zich hiertegen keren. 


\subsubsection{Goed land}

Goed land heeft mooie rechte voren met gezonde gewassen ook in droge periodes: goede hoogte en goede kleur. Goed land bevat geen onkruid en toont een egaal gewas dat meegaat met de rest van de gewassen in het gebied of hier juist op voorloopt. "Aan onkruid kweken moet je niet beginnen, dat is troep, daar ben ik geen boer voor." Goed land vertoont geen vervallen plekken. Op goed land blijft geen water staan als het regent. Goed land is land dat voldoet aan de functie of eisen: "In een goed perceel aardappelen staat geen onkruid. Als het doel is om de veldleeuwerik te herbergen, dan moet het juist weer geen strak perceel zijn." Een andere respondent verwoordt het zo: "Goed land is land met een rijk insectenleven, fauna en flora. Goed land is een mooi, schoon perceel dat toont hoe het gewas groeit, goed van kleur." Eén van de respondenten denkt dat het idee van goed land als strak land niet langer houdbaar is: "De norm lijkt te zijn: hoe strakker, hoe mooier. Geen onkruid, alles kort gemaaid, het ziet er goed uit. Insecten nemen dan wel af. In de polder is het voor een bij een groene woestijn. Die bloeiende slootkant kan ontzettend nuttig zijn als uitvalbasis. Als je geen bloemen hebt, kunnen natuurlijke vijanden niet overleven (...). Het mag tegelijkertijd wel iets netter bij mij. Spuiten werkt niet altijd en het weer heeft ook invloed. Maar als het dan weer bloeit dan denk je: dat is ook weer ergens anders goed voor. Op de groene school hing vroeger zo'n papiertje: 'wie zijn roet een jaar laat staan, kan zeven jaar aan het wieden gaan.' Als het mooi en strak is en alles lukt met onkruidbestrijding is het een groene woestijn en wordt het voortbestaan van insecten bemoeilijkt."

\subsubsection{De invloed van culturele normen}

\section{Rondjes rijden en daar rekening mee houden}

Als respondenten elkaar beoordelen doen zij dat op verschillende manieren. Zo kan er gekeken worden of de oogst beter of slechter is van gewassen. Alle boeren kennen elkaar en de percelen (goede, minder goede grond) en gewassen. Noord-Beveland is een eiland en er wordt veel gesproken over elkaar. Naar elkaar toe worden vooral complimenten gemaakt. Negatieve meningen worden tegen de buurman geuit, maar kritiek wordt vaak niet direct aan de boer zelf gegeven. Als er toch negatieve geluiden de boer bereiken, geeft deze vaak aan er weinig aan te kunnen doen, ook als zij er wel toe in staat waren. Er wordt vooral naar gewassen en land gekeken. Vanwege gewasrotatie kan het gebeuren dat er wel eens een minder geschikt gewas op een perceel staat (daar is begrip voor). Bij boeren waarvan gedacht wordt dat het beter kan, gaat het om meer gewas van het land halen. In de focusgroep wordt het beeld bevestigd: "20 jaar geleden reden we allemaal over de $x$-dijk en daar woonde boer $x$ en zo wilde niemand het hebben" (gelach, herkenning in de groep).

Een boer waarschuwt dat hier een verkeerd beeld uit naar voren kan komen bij alle beoordelaars van buitenaf: "Soms ziet het gewas er mooier uit dan het is. Overal staat het gewas er wel eens beter bij dan bij mij. Ze denken vast dat het bij mij ook een klein beetje een zooitje is. Maar bij de buren worden de wortelonkruiden erger en bij mij minder. Zij durven behoorlijk te spuiten en houden het wel kort, maar mijn bodemkwaliteit is beter dan die bij de buren." Rond onkruid blijft hij daarmee deels rekening houden met mening van anderen en deels niet.

Collega's kijken niet negatief naar boeren die meer aan natuur doen. Verder wordt aangegeven dat boeren in hun beheer geen rekening houden met rondrijdende collega's en dat een boer daar ook niet op inspeelt door de kanten langs de sloot wel schoon te wieden en de rest niet. Een andere boer bevestigt dat je niet bewust de zichtlocatie meer op orde houdt dan de rest. De twee oudere boeren geven aan vooral hun eigen plan te trekken. Eén van hen: "je probeert wel op anderen te letten, maar niet te veel. Ze zien liever niet dat stekels in bloei komen. Daar moet je wel eens ingrijpen. Aan de andere kant denk ik: als er klachten komen, zijn er daar hele goede natuurwaarden voor insecten. Dat zien ze niet. Het kan me niet zoveel schelen wat collega's er van vinden als ik meer voor de natuur ga doen."

\section{Cultuur van samenwerking}

Volgens de respondenten helpen boeren elkaar met oogsten, arbeid en machines. Op het gebied van mechanisatie wordt heel veel samen gedaan. Ook is er samenwerking met melkveehouders in de regio als het gaat om mest en hooi. Verder kan samenwerking bestaan uit het laten beheren van je land door een ander. Er is bij één van de boeren sprake van een werktuigensamenwerkingsverband: het betreft vooral samenwerking omtrent machines 
en arbeid met 3 collega's met vergelijkbaar land. De opbrengsten en de inkoop gaan hier niet gezamenlijk, zoals bij een andere boer die met vier andere bedrijven in een VOF werkt. Een VOF is een openbare maatschap die een bedrijf uitoefent. Het belangrijkste verschil tussen de maatschap en de VOF zit hem in de aansprakelijkheid. Bij een maatschap zijn de leden (maten) ieder voor een gelijk deel aansprakelijk voor de schulden van de maatschap. De leden van een VOF (vennoten) zijn ieder geheel aansprakelijk voor de schulden van de vennootschap, dus ook voor schulden die een medevennoot heeft gemaakt. De VOF gaat daarmee een stap verder qua samenwerking.

Een kleine teler merkt op dat hij erg afhankelijk is van zijn buren welke loonwerker wordt ingeschakeld. De Vereniging voor Bedrijfsvoorlichting (VVB) en de agrarische natuurvereniging Poldernatuur worden genoemd als vormen van samenwerking. Ook wordt samengewerkt rond de aanvraag van subsidies. Een boer hierover: "in je eentje red je het niet, te ingewikkeld."

\section{Gespreksonderwerpen}

Noord-Bevelandse boeren bespreken diverse onderwerpen die verband houden met de bedrijfsvoering: het weer, opbrengsten, verkoopprijzen, de markt, uitgangsmateriaal, materieel, plaagbestrijding, zaaien en planten, grondbewerking, het milieu en belemmeringen van natuur. Ze hebben het ook over de buren en wisselen sociale nieuwtjes uit.

\section{Hoe boeren leren}

De respondenten maken hun eigen afwegingen. Zij leren van elkaar op verschillende manieren: een proef met ZLTO-stuwtjes, een studiegroep, veldbijeenkomsten van de Vereniging voor Bedrijfsvoorlichting (VVB) voor een spuitlicentie, proefboerderij Rusthoeve. Bij Rusthoeve is er bijvoorbeeld een jaarlijkse uiendag. Er wordt ook geleerd van de VVB als het gaat om het verhandelen en verkopen van producten. Bij de VVB kan je in het groeiseizoen eens in de 14 dagen een ander bedrijf bezoeken. Daarnaast zijn er avonden vanuit de VVB over gewasbescherming en bemesting. Vier respondenten noemen de VVB als belangrijke kennisoverdrager en voorlichter. Twee respondenten noemen de agrarische natuurvereniging Poldernatuur als inspirator voor het leren van elkaar.

\subsubsection{Natuurinclusieve landbouw}

\section{Wat ze nu al doen}

De respondenten doen bijna allemaal aan een vorm van ANLb. Vijf van de zes boeren zijn al bezig met bloemrijke akkerranden. De boer die geen bloemrijke akkerrand heeft, zegt hierover: "je krijgt meer onkruiddruk en effect op natuurlijke plaagbestrijding is discutabel". De boer die geen bloemrijke akkerranden heeft, zou wel bereid zijn om over te gaan op een grasrand bij zijn akker of strokenteelt en vaste rijpaden.

De overige maatregelen hebben betrekking op bodembeheer (extensief bouwplan, niet te zware machines), het sparen van natuurlijke vijanden, stro hakselen, groenbemesters, vloeibare organische mest en vaste mest, nestbescherming, rekening houden met bijen, niet kerende grondbewerking, organische stof in de bodem brengen of het infecteren van grond met goede bacteriën. En bloemenranden: "Natuurvriendelijke teelt is ook een teelt, met een goed saldo. En ik vind het een leuke teelt, ik doe dat liever dan aardappelen telen met een hoge milieubelasting. Ik zie een heleboel bijen en hommels in die bloemenranden, dat doet me goed."

De meeste respondenten schalen zichzelf in als natuurinclusieve landbouw niveau 1. Twee boeren geven aan meer richting 2 te zitten vanwege het sparen van natuurlijke vijanden. Een boer hierover: "Categorie 2 is het hoogst haalbare in Noord-Beveland (ANLb met kringlopen en natuurlijke plaagbestrijding). Die akkerranden zie ik gewoon als een gewas waarvoor betaald wordt."

\section{Wat helpt om meer te doen}

Alle boeren geven aan dat een goede vergoeding helpt. Een boer hierover: "zonder goede vergoeding ploeg ik de akkerranden weer om." De subsidie bedraagt nu 2.100 euro per hectare voor een bloemrijke akkerrand. Een boer 
zegt: "Er moet financieel wat tegenover staan. Grond is ook geld, er moet geld mee verdiend worden. Aan een bloemenrand hoef je niet te verdienen, als de onkosten er maar uit zijn." De vergoeding voor grasland bedraagt nu 1500 euro per hectare. Om bij de teelt milieu- en natuurvriendelijker te kunnen boeren moet je volgens een boer "meer voor je producten krijgen en dat zie ik nog niet gebeuren, maar misschien kan het ook via een bijdrage van de samenleving. De boer moet wel kunnen overleven."

Omtrent beleid en regelgeving om boeren tot meer natuurvriendelijk gedrag te krijgen, verschillen de opvattingen onder de boeren. De een gelooft helemaal niet in regelgeving: "je kunt het niet afdwingen, dan ontstaat weerstand." Een andere boer geeft het volgende aan: "ik heb niets tegen strenge regelgeving, wel tegen betutteling. Ik wil graag de waaromvraag ergens naast leggen. Duidelijk in kaart brengen van de nulsituatie, kansen en bedreigingen. Verder het tegengaan van predatie."

Een boer geeft aan dat verdere technologische ontwikkelingen en verder onderzoek naar het natuurvriendelijker maken van huidige (chemische) gewasbeschermingsmiddelen kunnen helpen om meer te doen. Omtrent kennis zijn er nog onzekerheden over natuurlijke vijanden. Het effect van natuurlijke plaagbestrijding is volgens de meeste boeren (op één na) moeilijk aan te tonen. Dit kan weerslag hebben op de beslissing om al dan niet over te gaan tot een bloemenakkerrand of op al dan niet inzet van gewasbeschermingsmiddelen. Een boer geeft aan het een opgave te vinden om eerst te gaan monitoren en dan pas een bespuiting te doen. Een andere boer hierover: "Je moet ervaring opbouwen om te weten hoe lang je kunt wachten met een correctiemiddel. Mijn monitoringdata zeggen dat er patrijzen, graspiepers en leeuweriken voorkomen, doelsoorten waarvoor jezelf meldingen moet doen."

Tot slot geeft een boer aan dat hij de laatste jaren veel bezig is geweest met bodemverbetering: luzerne, veel organische mest en groenbemesters. Overhoeken worden beplant met bosschages voor planten en vogels. "Wij hebben geen emissies naar sloten: tegen de sloot aan is 3-4 meter gras, daarna 3-4 meter bloemenrand en daarna 4 meter zwarte aarde."

\section{Kan natuurinclusief deel uitmaken van goede landbouw?}

De casestudy Noord-Beveland levert diverse aanknopingspunten op waarom en hoe natuurinclusief deel kan uitmaken van goede landbouw.

Natuurvriendelijke teelt (akkerranden) is ook een teelt, met een goed financieel saldo als de opbrengst van de natuurteelt wordt afgezet tegen de geringe arbeid en kosten. Als het gaat om bodemverbetering dan willen de respondenten ook echt resultaat zien: wat gebeurt er als er niet wordt gespoten met gewasbeschermingsmiddelen? Verdwijnen ziekten en plagen met natuurlijke plaagbestrijding? Nu lijkt het vooral van de risicoafweging van de boer af te hangen en hoeveel tijd een boer zichzelf gunt om het experiment aan te gaan. De natuurwinst die wel al deels wordt geboekt, is dat preventief spuiten (nog voordat ziekten of plagen zich voordoen) plaats maakt voor minder proactief spuiten of zelf voor reactief spuiten (als ziekten en plagen zich voordoen).

Uit de verhalen van de respondenten van Noord-Beveland is op te maken dat natuur steeds leuker wordt als je er ervaring mee opbouwt en het vaker ziet. Meer kennis over verschillende aspecten van natuur, namelijk kennis van akkerranden, duurzaam bodembeheer, algemene en bijzondere flora- en fauna soorten natuur- en landschapsbeleving, maakt dat ze het meer gaan zien. Het ontzien van de bodem door een combinatie van rijpaden en bloemrijke akkerranden en de mogelijkheden die akkerranden kunnen bieden voor natuurlijke vijanden en het verhogen van de biodiversiteit doen de animo voor akkerranden stijgen, al blijven financiële vergoedingen hiervoor een belangrijke drijfveer. Opvallend is dat de respondenten de ervaring delen dat ze extensief boeren - in de zin van meer tijd uittrekken voor gewasrotatie wat de bodemkwaliteit verbetert, want de kans op ziekten en plagen vermindert - dezelfde of een betere opbrengst zien geven. Gewasrotatie komt een gezonde bodem ten goede. Het laat maar weer eens zien dat strak en netjes voor de respondenten in NoordBeveland wel heel belangrijk is, maar dat zij met een extensieve gewasrotatie ook bijdragen leveren aan de bodemkwaliteit en daarmee aan natuuraspecten die niet direct voor het oog waarneembaar zijn. 
Het landschap van Noord-Beveland zelf is uiteraard ook sturend voor de aangrijpingspunten van natuurinclusieve landbouw. Het is een land van polders tussen de dijken. Het gebied wordt gedomineerd door gelijksoortige akkerbouwbedrijven waarmee het beeld van een monocultuur ontstaat, uitgezonderd van enkele natuurgebieden van Staatsbosbeheer: Goudplaat en de Schotsman. De boeren hebben verbinding met het landschap: de weidse vergezichten en de bloemrijke akkerranden krijgen zowel van de boeren zelf als van de inwoners en recreanten waardering. Van een kleinschalig coulisselandschap is in Noord-Beveland geen sprake: hier geen hagen, elzenzingels en kilometers hakbos. Wel kan het landschap misschien in de toekomst weer meer terug veranderen in het krekenlandschap dat het vroeger was. Vraagstukken omtrent verdroging doen hier al stemmen voor opgaan, al zitten veel boeren er niet op te wachten om hun land weer op te offeren aan kreken. Nieuwe kreken kunnen wel nieuwe mogelijkheden bieden voor natuurinclusieve landbouw.

De boeren waarderen natuur als extra financiële vergoeding als het gaat om akkerranden en zien dit als een gewas dat ook nog veel plezier geeft. Ook een goed en duurzaam bodembeheer laat zich volgens hen vertalen in goede gezonde gewassen die leiden tot goede financiële opbrengst. De betekenis van akkerranden en onkruid voor natuurlijke plaagbestrijding roept nog discussie op bij de boeren: de meeste boeren zijn nog niet overtuigd van natuurlijke plaagbestrijding. Hier lijkt nog winst te kunnen liggen, evenals combinaties met strokenteelt in de toekomst.

De diversiteit van de bevraagde landbouwbedrijven was gering. Of de boeren opschuiven richting natuurinclusieve landbouw en of de tendens naar nog exclusievere landbouw zich door zal zetten in Noord-Beveland valt te bezien. Een toename van kennis over natuurinclusieve landbouw kan hierbij bepalend zijn, evenals het leren van boeren, zowel individueel als georganiseerd. Voor dit laatste wordt het praktijknetwerk van de Rusthoeve wel genoemd en verder vooral de voorlichting en bijeenkomsten die georganiseerd worden vanuit de CZAV (coöperatie) en de Vereniging voor Bedrijfsvoorlichting. De agrarische natuurvereniging Poldernatuur wordt minder genoemd, terwijl alle respondenten hier wel lid van zijn. 


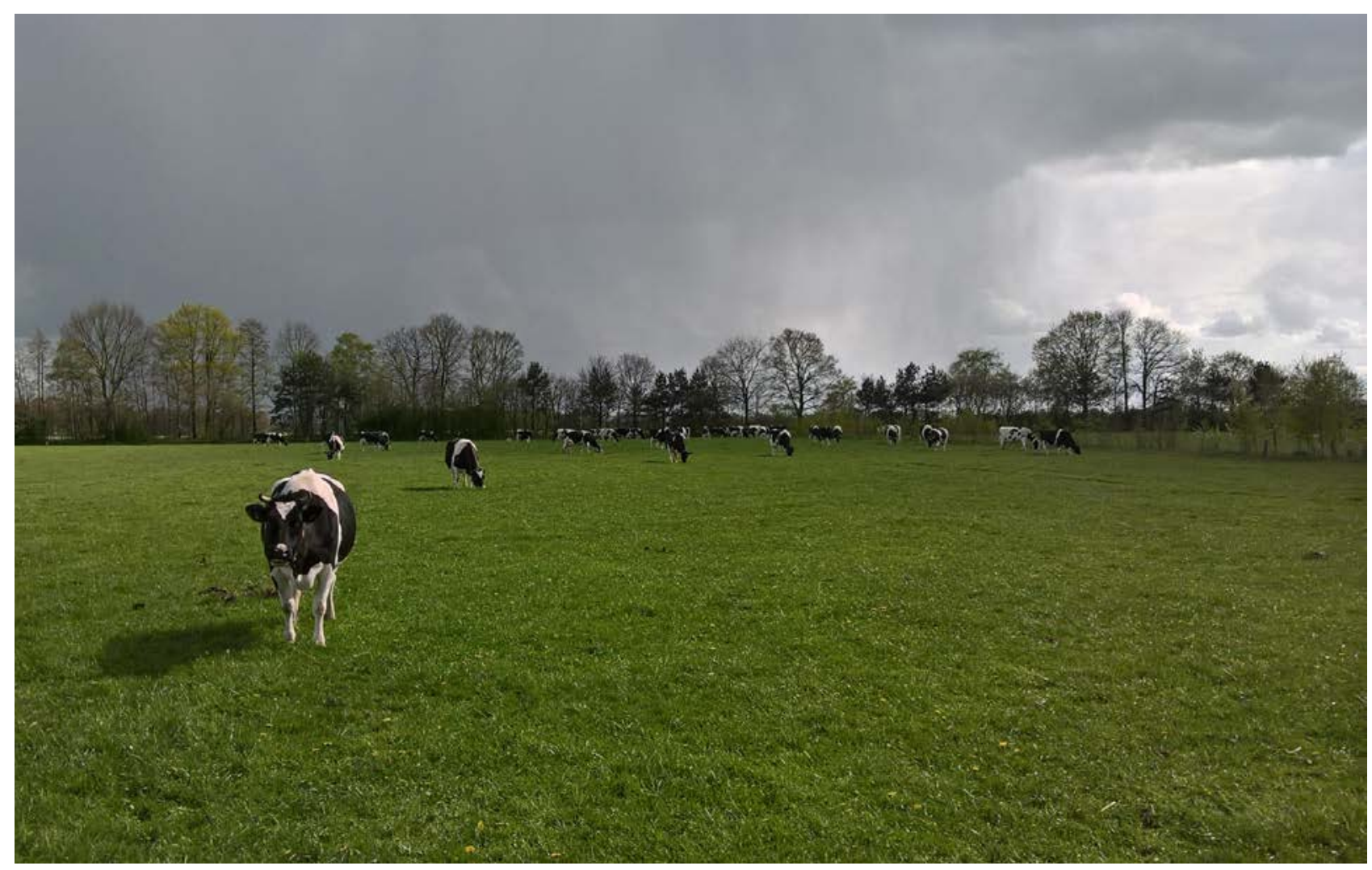

\subsection{Achterhoek}

\subsubsection{Typering deelnemende boeren}

De respondenten in de Achterhoek hebben allemaal een melkveebedrijf en één heeft ook vleesvarkens. Het gaat om twee grote bedrijven (130-240 koeien, 55-140 ha) en 4 kleine bedrijven (50-75 koeien, 25-45 ha). De leeftijd van de respondenten ligt tussen de 30 en 50 jaar (geschat door de interviewer). De meeste respondenten zien zichzelf op niveau 1 of 2 , of zelfs 3 als het gaat om de mate waarin men natuurinclusief bezig is (zie Kader 1 op p.12). De grootste boer heeft ook land van Staatsbosbeheer in beheer.

\subsubsection{Goede boer}

\section{Zelfidentiteit en drijfveren}

De respondenten omschrijven zichzelf als boer op verschillende wijze: koeienboer, ondernemer, kostprijsboer, gevoelsboer, breed geïnteresseerde boer en mensenboer. De koeienboer heeft plezier in het werk omdat het afwisselend is. Hij probeert het zichzelf zo makkelijk mogelijk te maken, zodat hij het ook vol kan houden op latere leeftijd. De ondernemer vindt het leuk om mensen op de goede plek te zetten, een beetje met geld te toveren en te handelen. Hij doet het voor het geld ("het gezin moet eten, de boel moet bloeien"). De kostprijsboer zoekt balans en wil aan zijn werk een goede boterham verdienen. Hij vindt het brede pallet aan activiteiten het mooie van het vak; niet alleen in de stal of op het land zijn, maar ook de contacten met collega's en buren.

De breed geïnteresseerde boer vindt alleen voedsel produceren te beperkend. Hij houdt van uitdaging en heeft een aantal bestuursfuncties en is lid van de Rotaryclub. Hij werkt voor zijn eigen plezier, maar er moet wel een inkomen uitgehaald worden. "Wij zijn boeren in hart en nieren, maar we willen ook de welvaart van de burger kunnen genieten. Dus ja, uiteindelijk doe ik het voor mezelf." De gevoelsboer doet zijn werk meer op gevoel en is niet zo met cijfers bezig. Dat gaat hem ook goed af, druk en spanning is niets voor hem, hij doet het voor zichzelf. De mensenboer vindt boer zijn een mooi beroep, maar ook eenzaam. Daarom is hij ook paardrij-instructeur. "Ik moet mensen om mee heen hebben. Er zijn meer dingen in het leven als alleen op de boerderij." Hij vindt het fijn dat hij zijn eigen dag in kan delen, maar al die regels beperken het vrije beroep wel.

Men haalt er voldoening uit als de koeien gezond zijn, het bedrijf financieel op orde is, het werken met vee en het resultaat dat dat oplevert of dat er sprake is van lichte groei. De regelgeving en de druk vanuit de overheden wordt door een aantal vervelend gevonden, maar het hoort ook bij de tijd en het is belangrijk dat je er mee om kunt gaan. Op de achtergrond speelt het gevoel dat de problemen van boeren niet door de maatschappij (h)er- 
kend worden. Het wordt daardoor ook als een probleem gezien voor toekomstige generaties, die het minder zal trekken om het bedrijf over te nemen. Eén respondent vindt de grootste ergernis dat steeds meer mensen in de steden wonen die niet weten hoe het er op het platteland aan toegaat, maar wel bepalen wat daar gebeurt.

\section{Goede/slechte boer}

Een goede boer heeft het productieproces goed in de vingers, zorgt goed voor dieren en milieu, heeft een goed verdienmodel, heeft plezier in zijn werk en heeft ook tijd voor andere dingen zoals maatschappelijke activiteiten. Volgens een respondent is een goede boer tevreden met hetgeen hij doet en het maakt niet uit of dat met veel of weinig koeien is. Of een boer lekker in zijn vel zit kun je zien aan het erf dat mooi opgeruimd is, de berm die bijgewerkt is. Twee respondenten vinden dat je een goede boer niet kunt herkennen, want boeren zijn heel verschillend: "Een boer die gericht is op kostenbeheersing is niet beter of slechter dan een boer die gaat voor maximale productie." Volgens de respondenten bestaan echt slechte boeren niet, omdat iedereen het op zijn eigen manier doet. Als het slecht gaat, heeft dat vaak een reden.

\section{Culturele norm in dit gebied}

Volgens een respondent wordt je als boer gerespecteerd door je collega's als je risico's durft te nemen, maar ook een pas op de plaats durft te maken. Een andere respondent vindt dat je aanzien hebt als je niet alleen op de zaak past, maar het bedrijf ook verder ontwikkelt. Hij gaat met de tijd mee, maar moet niet opvallen. In dit gebied is het toch een beetje "doe maar gewoon, dan doe je al gek genoeg." Je eigen leven leiden, open en eerlijk zijn dwingen ook respect af.

\section{Samenvatting}

Er zit een duidelijke relatie tussen wat boeren over zichzelf zeggen en wat ze een goede boer vinden.

Respondenten die vinden dat een goede boer maatschappelijke actief moet zijn, zijn dat zelf ook, want zij vinden boer zijn te beperkt en halen ook voldoening uit andere activiteiten. Anderen ontlenen plezier aan het werk en vinden dat een goede boer dat ook moet hebben. De grootte van het bedrijf is niet belangrijk, want iedereen kan op zijn eigen manier een goede boer zijn.

\subsubsection{Goed land}

Goed beheerd land is land met weinig of geen onkruid en een gezond bodemleven. "Het is mijn duurste productiemiddel, het moet renderen dus kan ik me niet veroorloven om het te verwaarlozen." Goed beheerd land heeft ook een goede opbrengst van smakelijke gewassen. Dat is een verdienmodel waar een goede boer naar streeft. "Ik vind het prachtig als ik een veld monocultuur gras, mais of aardappels heb, maar ik kan me voorstellen dat een burger daar wat andere visie over heeft. Een boer met minder mooi gewas hoeft echter geen slechte ondernemer te zijn, als die boer er bewust voor kiest om minder mest te gebruiken, minder kosten te maken en een minder opbrengst te krijgen. "Als je de mais van een biologische boer ziet dan schieten je de tranen in de ogen. Tenminste, als gangbare boer. Hij kan het er denk ik mee doen. Ja, wat is slecht? Maar als het onkruid zo hoog staat als de mais, dan ben ik blij dat mijn mais er niet naast staat."

De respondenten vinden dat het land van hun buren over het algemeen goed onderhouden wordt, maar sommigen verhuren land aan aardappelboeren en dan krijg je arm land. Op korte termijn levert het geld op, maar op langere termijn levert het slechtere mais op.

Eén respondent staat het tegen om glyfosaat grootschalig in te zetten om groenbemesters van het land af te krijgen, omdat je met bewerking ook hetzelfde effect kan krijgen. Naar burgers toe vindt hij al die doodgespoten weilanden een negatief signaal. Hij zou graag glyfosaat willen bewaren voor de noodzakelijke onkruiden. "En dan moet je als sector ook zeggen van oké, we gaan het gebruik landelijk met driekwart verminderen. Nou goed, maar er zijn boeren die denken laat mijn buurman dat maar doen, ik ga lekker door en daar erger ik me nogal eens aan." 


\subsubsection{De invloed van culturele normen}

\section{Rondjes rijden en daar rekening mee houden}

De respondenten trekken hun eigen plan en houden daaraan vast. Ze vinden het niet belangrijk wat anderen van hun werkwijze vinden. "Iedereen doet het op zijn eigen manier en die vrijheid mag je als boer hebben." Er wordt over elkaar gesproken en op elkaar gelet, maar dat wordt als menseigen gezien. Soms is het zichtbaar soms niet.

\section{Cultuur van samenwerking}

Er worden over en weer hand- en spandiensten verricht. "Als ik druk ben, spring er wel eens een buurman bij en andersom ook." Andere respondenten benoemen het gezamenlijk uitruilen van machines en er is een inkoopgroep waarmee met ca. 30 boeren gezamenlijk krachtvoer en diesel wordt ingekocht. "Van oudsher is dit wel een vrij coöperatieve regio."

\section{Gespreksonderwerpen}

Volgens de respondenten spreken boeren over koeien, gras en het weer, over wet- en regelgeving en welke gevolgen dat heeft voor de bedrijfsvoering, over beeld- en beleidsvorming in Den Haag, maar ook over het nieuws van die dag. "Niet over landbouw per se, soms wil je het ook over iets anders hebben." Als er sprake is van een vriendschap praten de respondenten ook over privézaken zoals familie etc. Eén respondent merkt op dat hij ervoor waakt dat hij alleen contacten heeft met boeren, want hij wil zijn geest ook graag scherpen aan de rest van de wereld.

\section{Hoe boeren leren}

De respondenten leren van collega-boeren. Dit varieert van kleine praktische dingen tot bodemverbetering. Ook van stagiaires wordt geleerd, omdat zij vaak vragen naar het waarom van werkzaamheden. Een aantal respondenten neemt ook deel aan studiegroepen, waarin onderwerpen aan bod komen als bodemverbetering en de kringloopwijzer. Ook vergaren de respondenten kennis uit vakliteratuur en van internet en vergaderingen.

\subsubsection{Natuurinclusieve landbouw}

\section{Wat ze nu al doen}

Een aantal respondenten onderhoudt hagen, hakhoutbos en singels zowel met als zonder vergoeding.

"Wij hebben twee houtsingels van drie meter breed en 400 meter lang en die hebben ook een Europese status gekregen doordat ze zo bijzonder waren, want die werden vroeger onder andere gebruikt om de kachel te stoken of als productiehout en de brandnetels en distels was bescherming voor het wild in de zomer. Ik vind dat wel leuk, nu weet je waar het voor diende en het is ook wel mooi om te zien, maar de vergoeding is gestopt." Een andere respondent heeft 1 ha hakhoutbos, hagen en singels. "Wij houden ze in stand door ze zelf of te laten snoeien, want het grootste nadeel van bos en hagen is dat ze agressief groeien, en wij willen onze landerijen niet laten opeten door bos, dus we moeten ze bijhouden."

Eén respondent doet aan akkerrandenbeheer om de minder productieve stukken langs de houtwallen ook tot waarde te kunnen brengen. "Omdat daar gewoon minder groeit en dat dan de wereld een stukje mooier wordt, dat is dan leuk meegenomen." Hij probeert het bodemleven te stimuleren door compost, bekalken etc. Dit is ook deels noodzakelijk door de huidige mestregelgeving. Hij heeft ook 25 hectare in pacht van Staatsbosbeheer. "Daar zitten flinke beperkingen op ten opzichte van mest en maaidata, maar het hooi kan ik goed bewaren en dat past eigenlijk wel als toevoeging bij mijn bedrijf." Eén respondent doet mee aan een patrijzenproject van de gemeente en de jagersvereniging en heeft een strook akkerrand ingezaaid.

Eén respondent doet niets aan natuurbeheer. Hij staat er niet negatief tegenover, maar wil er niet teveel werk aan hebben. Het moet ook praktisch uitvoerbaar zijn en geen geld kosten. "Die rand met zonnebloemen sprak me op een bepaald punt wel aan ja, en ik weet van Dick, hij is begaan met alles, maar het moet wel wat opleveren. Als hij het doet, kost het blijkbaar geen geld. Ja dat klinkt lullig maar zo is het. Friesland Campina is bezig met een nieuwe toplijn in de melk. Moet je $10 \%$ van je grond in natuurbeheer stoppen. $10 \%$ ! Voor 2 cent. Nou, ik dacht het niet. En niet voor het feelgood, echt niet." 


\section{Wat helpt om meer te doen}

De meeste respondenten zeggen niet meer voor natuur te kunnen doen. Daar is de grond te duur voor. "Oppassen dat we grond onttrekken aan de landbouw voor woningbouw of natuur." Ook ontbreekt bij sommigen de tijd om meer voor natuur te doen. Een stukje waardering zou wel helpen, maar wat je voor natuur doet, moet in verhouding staan tot andere inkomsten op de boerderij. "Wij hebben een omzet van ongeveer 500.000 euro per jaar en dat is allemaal melk en vlees. Op het moment dat daar 1000 euro natuur bij komt, dan is dat marginaal." Ook vindt men dat de overheid onbetrouwbaar is; er ontbreken langdurige contracten evenals een lange termijnvisie. "Als ik me ergens aan irriteer dan is het wel dat het elke keer weer veranderd wordt; eerst doet het rijk het en dan de provincie en nu doet agrarische natuurvereniging Onderholt het, de regels veranderen en soms verandert de vergoeding ook in negatieve zin." Eén respondent vindt de definitie van natuurinclusief vaag en vrijblijvend. Hij ziet graag een doelgerichte oplossing en middelen omdat te bereiken, evenals het benutten van krachten in het veld. "De een is goed in weidevogelbeheer, een ander in akkerranden." Men wil zeggenschap want het is plezieriger om zelf de keus te kunnen maken. Ook speelt een rol of een boer het zelf leuk vindt (dan sta je er meer open voor), en de levensfase waar de boer zich in bevindt is ook van invloed.

\section{Kan natuurinclusief deel uitmaken van goede landbouw?}

De casestudy Achterhoek biedt enkele handvaten hoe natuurinclusief deel kan uitmaken van goede landbouw. De respondenten zijn van mening dat het wel past in een gebied met veel houtwallen en een enkeling waardeert de historie van het landschap. Minder productief land toch tot waarde brengen is een reden om mee te doen met agrarisch natuurbeheer. Het besef groeit dat er een omschakeling gaande is naar meer natuurinclusief boeren. De Top-Zuivellijn van FrieslandCampina is daar een voorbeeld van. Daarvoor moet je aan criteria voldoen, maar de respondenten verwachten dat het over 10 jaar de norm is waar iedereen aan moet voldoen. "Ik denk dat als wij met de gangbare landbouw zo doorgaan in dit tempo dat we binnen een tijd ook biologisch zijn. Op dit moment voel ik me nog niet helemaal happy erin, want het antibioticumgebruik is heel strikt en kunstmest is uit den boze, misschien moeten we daar op den duur anders tegenaan kijken, maar ik kan het nu op het moment nog niet missen." Toch vindt men het een goede zaak om bewust bezig te zijn met het product en transparantie naar de burger te creëren.

Twee grote obstakels houden boeren in de Achterhoek nu tegen om natuurinclusief in de bedrijfsvoering te integreren. De eerste is de miskenning vanuit de maatschappij voor de hoeveelheid tijd en moeite die het kost en de lagere opbrengsten door natuurinclusiever te boeren. Dat zit hen erg hoog. En de tweede is de hoge gronddruk die hen ertoe noopt elk stukje grond te benutten. Het ontbreken van commercieel perspectief voor natuurinclusieve landbouw leidt ook tot een conservatieve opstelling. Natuurinclusief kan met andere woorden alleen deel uitmaken van goede landbouw als het van twee kanten komt. 


\subsection{Noordelijke Friese Wouden}

\subsubsection{Typering deelnemende boeren}

De respondenten in de Noordelijke Friese Wouden hebben allemaal een melkveebedrijf. Het gaat om twee grote bedrijven (180-185 koeien, 115-135 ha), een middelgroot bedrijf ( 110 koeien en 65 ha) en drie kleine bedrijven (45-85 koeien, 50-65 ha). Een van hen beheert ook land van Staatsbosbeheer. De kleine bedrijven zijn verbreed met campings, een kaasmakerij of snijheesterteelt. Ze delen zichzelf allemaal in in niveau 2 van natuurinclusief (zie Kader 1 op p.12). De respondenten willen hun huidige omvang consolideren of nog beperkt groeien. Ze streven niet naar een supergroot bedrijf, omdat ze allemaal een leven naast de boerderij ook heel belangrijk vinden. Het gaat om veertigers en vijftigers. Een respondent heeft in 2015 een nieuwe stal gebouwd, maar kan vanwege de fosfaatrechten niet de volledige capaciteit benutten.

\subsubsection{Goede boer}

\section{Zelfidentiteit en drijfveren}

De respondenten typeren zichzelf op verschillende wijze. Iemand noemt zichzelf een ondernemende boer: "Ik probeer alles te verbeteren, als je iets doet, moet het geld en vrije tijd opleveren, dat vind ik heel erg belangrijk." Een ander omschrijft zichzelf als balansboer: "Ik streef naar balans, niet het maximum, maar het optimum; gezonde dieren, weinig krachtvoer, weinig kunstmest. Antibiotica gebruik ik bijna niet meer. Ook de hoeveelheid werktijd en vrije tijd moet in evenwicht zijn."

Een andere respondent vindt zichzelf een allroundboer: "Ik houd wel van nieuwe dingen. Ik ben zelf nergens heel goed in, maar ik kan alles wel redelijk." De verbrede boer: "We hebben een mini-camping, kaasmakerij en winkel en we recyclen natuurafval tot compost (bokashi). Als je verbrede landbouw goed oppakt, heeft dat zeker toekomst. Ik probeer nieuwe dingen te ontdekken; ik leef niet als slaaf voor de koeien, er zijn heel veel andere leuke dingen in het leven om samen te doen en uit te vinden." Er is ook een respondent die zichzelf eigenlijk niet echt boer voelt: "Ik ben een mensenmens. Koeien zijn hartstikke leuk hoor, maar dat is voor mij geen hoofddoel. Ik denk na hoe ik biodiversiteit kan implementeren in mijn bedrijf en ik heb ook een zorgboerderij."

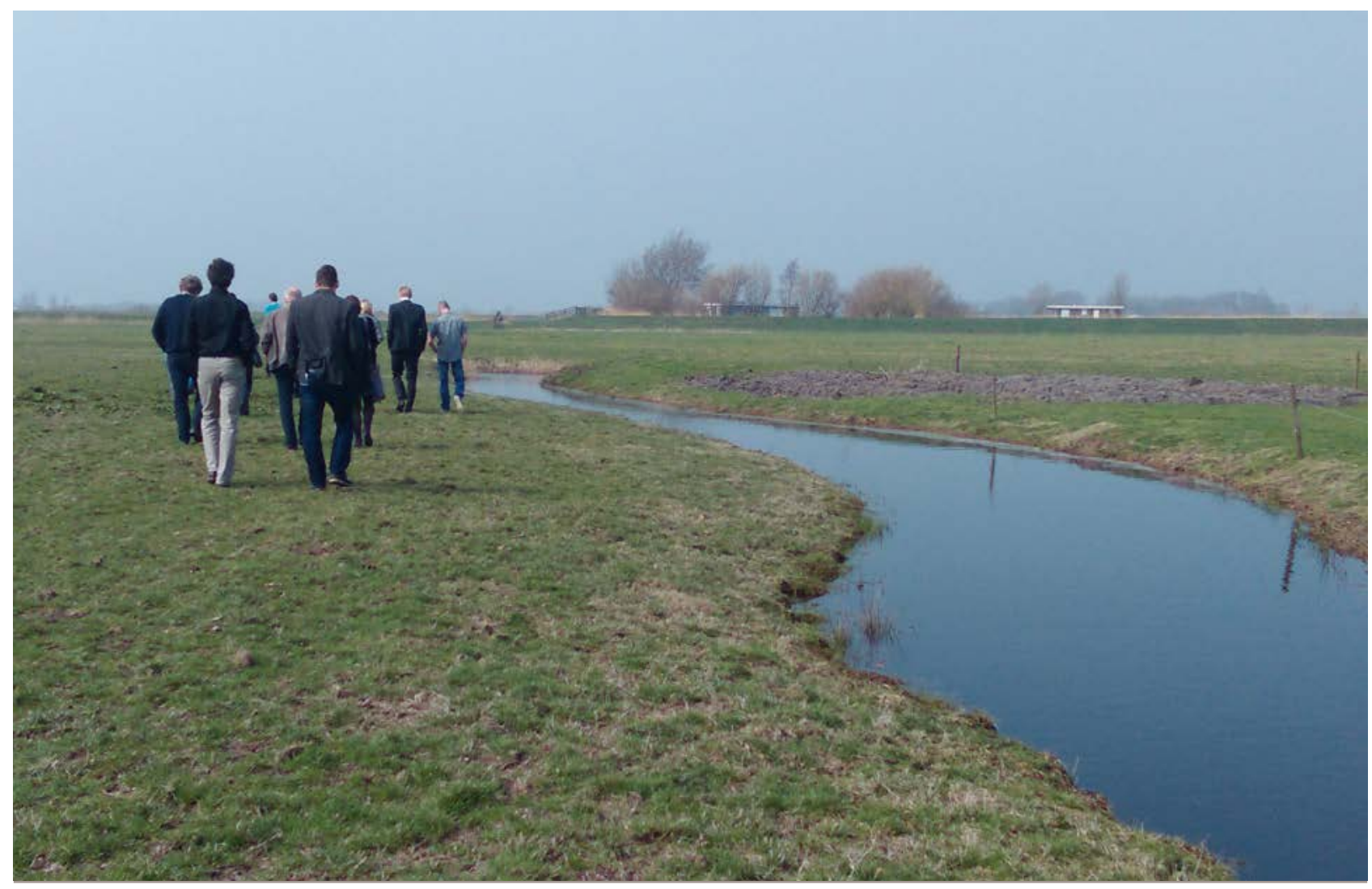


Voor alle respondenten is geld verdienen een belangrijke drijfveer: "Ik vind het heel mooi allemaal, maar het draait wel om geld, zo simpel is het." Een andere boer zegt: "Ik heb niet de intentie om groot te worden, maar de basis is om een inkomen te verdienen." Daarnaast vinden alle respondenten ook andere dingen belangrijk. Voor één respondent is het implementeren van biodiversiteit in de bedrijfsvoering ook deels zijn drijfveer: "Ik vind zelf leuk dus ik geniet er ook van, dus ik ben al jaren aan het experimenteren. Door een hogere biodiversiteit krijg je betere producten, dat moet je laten zien en verwaarden." Eén respondent benoemt dat hij het bedrijf goed over wil doen aan de volgende generatie, niet alleen in financieel opzicht, maar ook qua duurzaamheid van bijvoorbeeld de bodem. Andere respondenten genieten van het melken, de jaargetijden, samen met het gezin of anderen aan het werk zijn. Ook de aanwezigheid van vogels en bloemen motiveert de respondenten: "Ik mag graag door de randen lopen en bloemetjes zien, daar geniet ik echt van." "Ik heb al 8 jaar plas-dras, dan zet je land onder water voor de vogeltjes. Niemand wilde dat destijds doen. Nou zei ik, dan doe ik wel mee; ik wil er wel eentje maken. En eigenlijk is dat gewoon mijn paradijs 's zomers. Ja, geweldig. Wat een aantrekkingskracht voor vogels. En ik denk dat ik er in de toekomst nog eentje maak."

\section{Goede/slechte boer}

Volgens de respondenten is een goede boer iemand die goed voor zijn vee zorgt en niet alleen gericht is op boeren, maar ook op het leven en de maatschappij er omheen. Het bedrijf moet netjes zijn en toonbaar naar de maatschappij. Hij/zij kan zijn nota's betalen en ook nog van het leven genieten. Een goede boer is ook iemand die met verandering kan omgaan en daar op in kan spelen. En een goede boer moet alle aspecten van z'n bedrijf goed in zijn hoofd hebben en uitbesteden waar hij niet goed in is. In de focusgroep wordt opgemerkt dat het ook afhangt van welke maatstaven je hanteert voor een goede boer. "Als je een hoge productie belangrijk vindt, dan is de topmelker uit de buurt een hele goede boer. Maar je kunt ook het kringloopverhaal als maatstaf nemen en dan is een ander soort boer een goede boer." Ook wordt gezegd dat het lastig is om een bedrijf alleen vanaf de buitenkant te beoordelen, daarvoor is ook kennis nodig van de financiële situatie.

Bij een slechte boer is sprake van achterstallig onderhoud in het grondgebruik, het erf en de gebouwen. Een slechte boer heeft een bedrijf dat niet overgenomen kan worden. Volgens een andere respondent heeft een slechte boer zijn bedrijf niet in balans of zorgt hij slecht voor zijn vee. Ook denkt één respondent dat slechte boeren niet meer bestaan: "Die zijn er allemaal al uit en anders gaan ze er tussen nu en een paar jaar uit."

\section{Culturele norm in dit gebied}

Oog hebben voor de omgeving en de relatie met andere mensen en de maatschappij is belangrijk. In dat kader past ook het agrarisch natuurbeheer waar alle respondenten aan meedoen. "Ik word wel eens kwaad op boeren die gewoon door de nesten heen maaien, die moeten er niets van hebben, dan denk ik: kom op man, zet je er voor in." Het land en het bedrijf moeten ook netjes zijn, liefst de koeien buiten. In dit gebied wordt tegen niemand opgekeken volgens de respondenten. "Of iemand nu 200 of 20 koeien melkt dat maakt niks uit. Iedereen doet het op zijn eigen manier. De diversiteit in de sector, dat maakt het ook zo mooi." Een respondent vraagt zich af waarom iedereen steeds groter wil worden: "Ik zeg altijd: groot, groter, kapot." In de focusgroep wordt opgemerkt: "In onze tijd was het alleen maar groeien en groter, ik denk dat we dat punt nu wel een beetje bereikt hebben."

\section{Samenvatting}

Tussen wat boeren over zichzelf zeggen en wat ze een goede boer vinden, zit een duidelijke relatie. De respondenten willen geen slaaf zijn van de koeien; vrije tijd wordt belangrijk gevonden evenals de relatie met de maatschappij. Ze hebben respect voor de 'topmelker' uit de buurt, die bijna 15.000 liter per koe melkt, maar ze zouden niet willen ruilen en ze verwachten dat dat andersom ook niet het geval is: "Dus dan zou je zeggen dat is een goede boer. Maar ja, ik heb wel gehoord, hij is nog nooit op vakantie geweest." De respondenten streven niet naar een hoge productie; een kringloopboer kan ook een goede boer zijn. 
De respondenten vinden het ook belangrijk dat het bedrijf overgedragen kan worden aan opvolgers. Daarvoor is nodig dat het bedrijf financieel op orde is, maar ook dat je goed omgaat met de grond en bodem. "Als ik er een dikke bende van maak, mergel de grond uit en ik laat het niet goed achter, dan zit de opvolger met de gebakken peren."

\subsubsection{Goed land}

Goed beheerd land heeft een goede vrucht erin en geen onkruiden zoals stekels en ridderzuring. Een goede afwatering is heel belangrijk, evenals de bemesting: "Dat kun je zien aan de kruiden die je op het land hebt. Als je niet goed hebt bemest of ontwaterd krijg je hier pitrus en pitrus." In de focusgroep heeft men twijfels over het beheer van land door natuurorganisaties dat vooral pitrusvelden oplevert: "Daar zitten alleen maar vossen, terwijl het voor de weidevogels bedoeld was." En "Ik denk niet dat de natuurwaarde van dat land hoger is dan bij ons. Ik geloof niet dat daar meer weidevogels zitten." Een andere respondent is in de loop der jaren van mening veranderd over wat goed land is: "Vroeger wou ik het ook strak groen hebben, maar die tijd heb ik gehad." Volgens hem hangt dat ook samen met het financiële aspect en de leeftijdsfase: "Vroeger toen we jong waren, wilden we het maximale van het land afhalen, omdat er verdiend moest worden. Nu hebben we het mooi op de rit en dan zijn er ook andere dingen belangrijk. Je hoort steeds meer over natuur. Ook hebben partners vaak zelf een baan en werken niet meer mee. Dat betekent dat het inkomen ook wat minder kan." Alle respondenten zijn positief over randenbeheer: "Dat was een mooi stukje biodiversiteit, maar ineens was het afgelopen."

Volgens een respondent heeft goed land voldoende weerstand tegen onkruiden en veel organische stof in de bodem om de droogte op te vangen. Goed land hangt ook samen met het doel: "Goed beheerd land voor de weidevogels of goed beheerd land voor de koeien?" Een respondent maakt een vergelijking met het beheer van gronden door natuurorganisaties in het gebied. "Die vinden op hun manier dat dat goed beheer is, maar ik denk niet dat de natuurwaarde van dat land hoger is dan bij ons. Ik geloof niet dat daar meer weidevogels zitten dan bij ons."

\subsubsection{De invloed van culturele normen}

\section{Rondjes rijden en daar rekening mee houden}

De respondenten zijn het eens dat boeren over elkaar oordelen. Volgens de ene respondent is er gigantisch veel sociale controle in de landbouw, volgens een andere respondent zijn het vooral boeren zonder sociaal leven die naar andere boeren te kijken. Een respondent krijgt af en toe aardige complimenten van collega's over hoe zijn percelen erbij liggen. "Dan denk ik: dan doe ik het toch goed." De respondenten zeggen zich niet veel aan te trekken van de mening van andere boeren. "Als mijn buurman gaat maaien moet ik ook maaien. Nee dus. We maken ons hier niet druk om een andere boer." Eén respondent ervaart soms wel stress als alle boeren gaan maaien, en hij nog niet.

\section{Cultuur van samenwerking}

Volgens de respondenten is er niet echt een cultuur van samenwerking wat betreft arbeid op het bedrijf. Er is wel een cultuur van elkaar helpen als dat nodig is. "We doen niet echt dingen samen, maar als buurman met een probleem zit dan helpen we elkaar." Het lidmaatschap van de agrarische natuurvereniging Noardlike Fryske Wâlden wordt als samenwerking gezien. "We hebben een fantastische club met 800 leden en het kantoor met 5-6 mensen die veel werk voor ons verrichten. Daar zijn we heel trots op."

\section{Gespreksonderwerpen}

Volgens de respondenten spreken boeren onderling wel over de koeien en het weer, maar niet over de financiële situatie van het bedrijf.

\section{Hoe boeren leren}

De respondenten leren door naar studiegroepen en bijeenkomsten te gaan of als bestuurslid van een agrarische vereniging. "Ik ga zoveel mogelijk naar bijeenkomsten waar ik wat kan leren en dan probeer je dat zelf uit. Het is ook blik verruimend als je ergens anders kijkt." De respondenten zeggen ook te leren van collega's, al gebeurt dat niet op grote schaal. Ook internet wordt gebruikt om kennis op te doen. 


\subsubsection{Natuurinclusieve landbouw}

\section{Wat ze nu al doen}

Alle respondenten zijn lid van de agrarische natuurvereniging Noardlike Fryske Wâlden (NFW) en al jaren bezig met agrarisch natuurbeheer. Ze doen aan weidevogelbeheer (o.a. plas-dras, uitgesteld maaien), botanisch beheer en onderhoud van houtsingels. "We zijn met NFW met zijn allen die richting ingeslagen, met al die collectieven in de buurt. Dat past ook weer bij de Wouden misschien. Die hebben met $z^{\prime} n$ allen al gezegd we zijn iets anders bezig dan de rest van Nederland." De respondenten betreuren het dat de vergoeding voor randenbeheer is afgeschaft, want dat was een effectieve manier om biodiversiteit te bevorderen. Een aantal respondenten doet dat nu vrijwillig. "Het zou mooi zijn als het randenbeheer weer terug zou komen. Iedereen blijft toch al weg van de slootkant met zijn bemesting, die meter mis je niet." Daarnaast zijn een aantal respondenten bezig met het verbeteren van de bodem door minder kunstmest en bestrijdingsmiddelen te gebruiken en het recyclen van groenafval tot bokashi. "Ik ben in mijn maislanden aan het schoffelen geweest, want ik wil zonder bestrijdingsmiddelen gaan werken, want volgens mij richt dat heel veel schade aan in de bodem. Daar moeten we vanaf." Eén respondent gebruik VLOG voer (Verband Lebensmittel Ohne Gentechnik). Eén respondent denkt er over om biologisch te worden, omdat hij ziet dat het anders moet. Dat is echter voor hem een leer-denkproces dat een aantal jaren duurt. "Zo ging het ook met plas-dras; in het begin dacht men die is gek, maar nu kijkt niemand er meer van op." Enkele respondenten nemen ook energiebesparende maatregelen als zonnepanelen op het dak en ledlampen in de stal.

Natuurinclusieve landbouw is een ontwikkelingsproces waarin verschillende niveaus kunnen worden onderscheiden. Het merendeel van de respondenten ziet zichzelf op niveau 2: agrarisch natuurbeheer en het stimuleren van het bodemleven of natuurlijke plaagbestrijding. Ze proberen de bodem te verbeteren met bokashi. Een paar respondenten gebruiken ook minder kunstmest om de impact op natuur te verkleinen al is volgens één respondent de ondergrens qua bemesting wel bereikt "Ik denk dat daar ook al een hele slag gemaakt is. Mijn vader deed 400 kilo zuivere stikstof op een hectare. Ik denk dat de gemiddelde boer hier op 100-150 zit."

\section{Wat helpt om meer te doen}

De respondenten vinden dat ze al veel voor de natuur doen. Ze lopen langzamerhand tegen hun grenzen aan, omdat bijvoorbeeld gras van mindere kwaliteit niet onbeperkt ingepast kan worden in de bedrijfsvoering. Een goed verdienmodel vinden ze een belangrijke voorwaarde om meer te doen voor de natuur. "Het verdienmodel agrarisch natuurbeheer is maar beperkt, wij hadden hier weidevogels, maar het loopt niet goed bij mij achter huis, dus over vier jaar stopt het, logisch, maar dan is mijn verdienmodel ook weg." Ook minder regels zou kunnen helpen. De $80 \%$ grasland / $20 \%$ bouwland regeling beperkt nu bijvoorbeeld de mogelijkheid om meer krachtvoer van het land te halen of om met een aantal collega's een kleinschalige kringloop op te zetten. Men ziet in verband hiermee ook graag dat de boer de vrijheid krijgt om binnen de gevraagde kaders te werken. "Niet iedereen hoeft hetzelfde te doen." In de focusgroep wordt opgemerkt dat er kennis nodig is over $\mathrm{CO}_{2}$ vastlegging en dat het nodig is om via het collectief een persoon aan te trekken die dat voor de boeren gaat regelen. Ook goede communicatie is belangrijk en dat gebeurt ook.

Het randenbeheer zou terug moeten komen. "Dat begon net effect te krijgen, maar nu is alles weer weg." Elke boer zou op $10 \%$ van zijn land natuur moet hebben. "Als je met andere boeren daar over praat, vinden ze dat heel veel, maar ik denk: je hoeft alleen maar je randen te doen en dan ben je al klaar en het effect op het leven van dieren is gigantisch." Eén respondent merkt op dat de natuur niet overheersend moet worden. "Dat alles om de natuur draait, dat is natuurlijk ook niet goed." Andere respondenten missen een duidelijke richting welke kant het op moet met natuurinclusief boeren en vinden dat er wel wat meer voorlichting mag komen over natuurinclusieve landbouw. "Dat concept is niet voor iedereen mogelijk en mensen voelen zich hierdoor in een hoekje gedreven." Door de respondenten wordt opgemerkt dat sommige boeren wars zijn van bemoeizucht, die willen gewoon boer zijn zonder rompslomp. Maar ook: "De grote winst is te halen bij boeren die nu nog niks doen." 


\section{Kan natuurinclusief deel uitmaken van goede landbouw?}

De casestudy Noordelijk Friese Wouden levert diverse aanknopingspunten op waarom en hoe natuurinclusief deel kan uitmaken van goede landbouw. Allereerst is de vereniging de Noardlike Fryske Wâlden (NFW) met 800 leden een belangrijke speler om de landbouw te vervlechten met landschap, natuur en cultuurhistorie. De respondenten zijn erg te spreken over deze vereniging, die hun helpt om zaken voor elkaar te krijgen. "We hebben met zijn allen de coöperatie NFW opgericht. Die 800 boeren hebben met zijn allen al gezegd: we zijn iets anders bezig dan de rest van Nederland. We hebben ook mensen in dienst die geldlaatjes in Den Haag los weten te trekken. Als dat niet gebeurt, is het ook met die 800 boeren gauw gebeurd." "Steun kun je als collectief wel krijgen, maar als individuele boer krijg je dat niet meer."

Daarnaast leent het kleinschalige coulisselandschap met elzensingels, dykswâlen en pingo's zich goed voor natuurinclusief boeren volgens de respondenten. "Het past bij de Wouden; als je boven Dokkum zit of in de Flevopolder kun je heel anders boeren." Agrarisch natuurbeheer is gebruikelijk in dit gebied en de respondenten doen ook mee aan nieuwe projecten zoals bokashi en $\mathrm{CO}_{2}$-vastlegging.

Natuurinclusieve landbouw past hier ook bij het beeld van een goede boer, en wat goed land is, hangt af van het doel. "Die plas-dras heb ik nu al 10 jaar, in begin dacht men: die is gek. Als ik nu plas-dras maak, kijkt een boer er niet meer van op." Er wordt een vorm van competitie gevoeld met terreinbeherende organisaties: weidevogelbeheer maakt deel uit van de boerentrots. De levensfase speelt ook een rol bij de omslag in het denken. "Je wordt ouder en je denkt misschien wat anders over het leven dan als je jong bent. Toen wilden we het maximale van het land afhalen, wilde ik het strak groen hebben, maar toen moest er ook worden verdiend. Nu hebben we het mooi op de rit en dan zijn er ook andere dingen die we kunnen doen."

\subsection{Algemene bevindingen}

\subsubsection{Vergelijking tussen casestudy's}

\section{Goede boer}

In alle casestudy gebieden geven de respondenten ongeveer dezelfde kwalificaties aan een goede boer. Een goede boer heeft het productieproces goed in de vingers en zorgt goed voor zijn dieren en gewassen. Een goede boer zorgt voor voldoende organische stof in de bodem en stemt de bemesting af op het perceel. Iemand dus die goed zorgt voor dieren en milieu. Het bedrijf moet netjes zijn en toonbaar naar de maatschappij. Een goed boer heeft ook een goed verdienmodel en kan zijn rekeningen betalen. Hij heeft plezier in zijn werk en ook tijd voor andere dingen zoals maatschappelijke activiteiten. Een goede boer is ook iemand die met verandering om kan gaan en daarop in kan spelen. Maar wat een goede boer is hangt ook af van welke maatstaven gehanteerd worden voor een goede boer. Als een hoge productie belangrijk wordt gevonden is iemand met een hoge melkproductie een goede boer. Als het kringloopverhaal als maatstaf genomen wordt, dan is een ander soort boer een goede boer. Om een boer als goed of slecht te kunnen beoordelen, is ook kennis nodig van de financiële situatie van het bedrijf.

\section{Goed land}

Aan iemands land kun je zien of hij of zij een goede boer is. De respondenten van alle casestudygebieden zijn het grotendeels eens over wat goed land is. Goed land heeft een mooi en gezond gewas, goede hoogte en goede kleur. Goed land heeft goede, vruchtbare grond en heeft een goede opbrengst. Het moet er netjes uitzien, goed bijgehouden en goed verzorgd. Rommelhoekjes passen daar niet bij. Goed land bevat nauwelijks onkruid. Een goede afwatering is belangrijk.

Desondanks komen uit Noord-Beveland, Midden-Limburg en de Noordelijke Friese Wouden geluiden dat er ook anders tegen het land wordt aangekeken. Een perceel wordt niet meer alleen gezien als een productieveld, maar ook als grond waar je natuur op kunt maken. Wat goed land is, hangt dus ook af van het doel. Wordt het beheerd voor de koeien of voor de vogels? In een goed perceel staat nauwelijks onkruid, maar als het doel is om vogels 


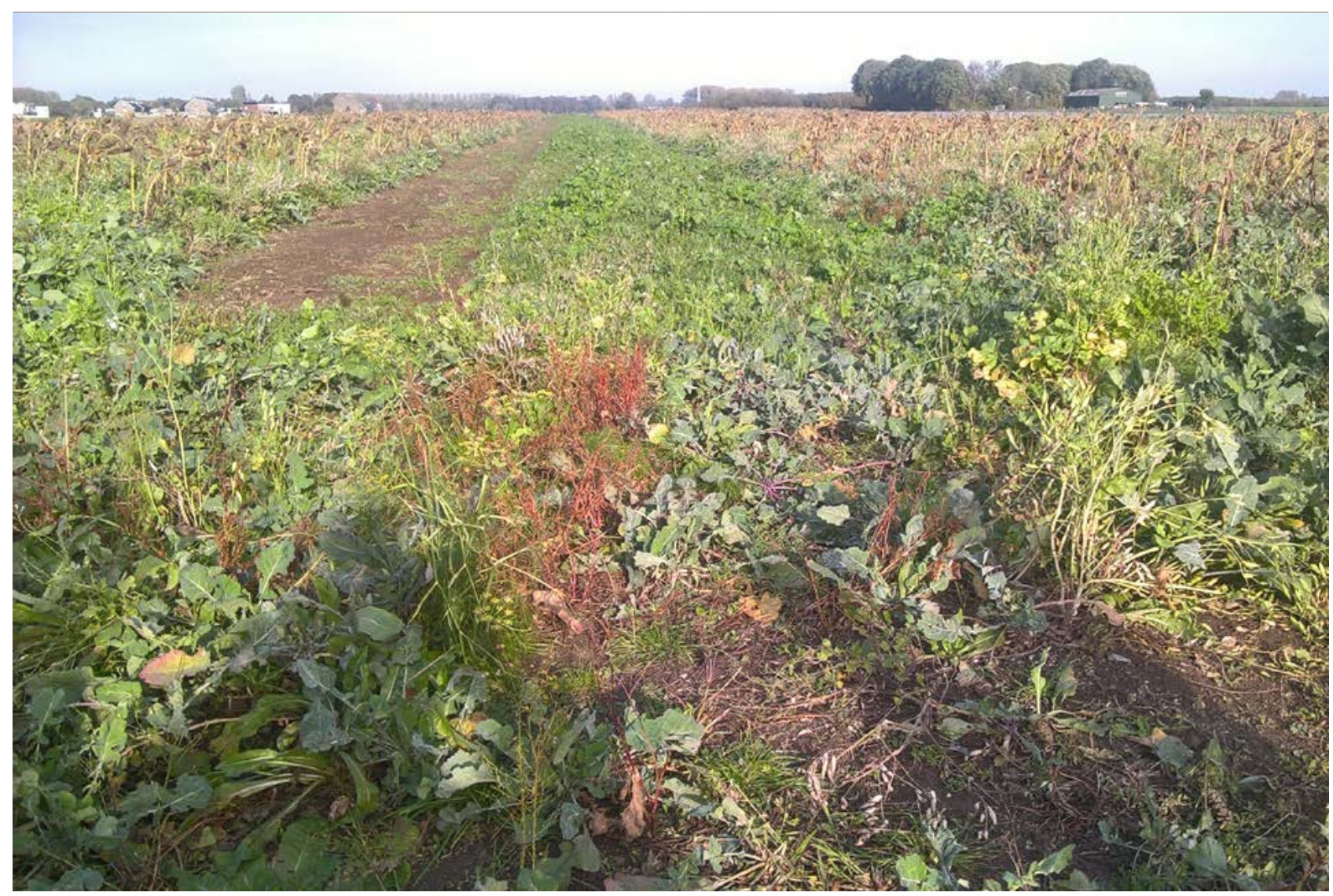

te trekken dan is goed land ook een patrijzenrand met zonnebloemen of een plas-dras met weidevogels. Er wordt dus niet alleen meer in voedselproductie gedacht. Vooral land dat weinig opbrengt omdat het te nat is, in de schaduw ligt of in een lastig bewerkbare hoek ligt, is bruikbaar voor natuur. In ieder casestudygebied is wel een respondent die ook de waarde ziet van land met een rijke flora en fauna, of het bewustzijn heeft dat een veld monocultuur gras of aardappels door de burger niet altijd gewaardeerd wordt. Deze verandering in de kijk op goed land hangt ook samen met de financiële situatie en de leeftijd van de boer. Strak groen wordt minder belangrijk als men ouder is en men financieel meer ruimte heeft.

\section{Rondjes rijden}

In alle casestudygebieden kijken boeren naar het land van hun collega's en vergelijken ze dat met hun eigen land. Boeren kijken naar het gewas, het vee, werkzaamheden, de oogst, nieuw gekocht land. Volgens de respondenten is het echter niet mogelijk om op basis van het land of de gebouwen de financiële situatie van een boer te beoordelen. Boeren zullen elkaar echter niet aanspreken op hoe het land erbij ligt. Soms worden wel complimenten gemaakt, maar negatieve kritiek wordt niet direct geuit. De respondenten zeggen zich niet veel aan te trekken van de mening van andere boeren. Ze trekken hun eigen plan en houden daaraan vast. Vooral in de Achterhoek zeggen de boeren het niet belangrijk te vinden wat anderen van hun werkwijze vinden. Er wordt over elkaar gesproken en op elkaar gelet, maar dat wordt als menseigen gezien. Diversiteit wordt in alle casestudy's gewaardeerd, maar in het bijzonder in de Achterhoek. 
Tabel 1 Vergelijking tussen casestudy's

\begin{tabular}{|c|c|c|c|c|}
\hline & Midden-Limburg & Noord-Beveland & Achterhoek & NFW \\
\hline Sectoren & Divers & Akkerbouw & Melkvee & Melkvee \\
\hline Goede boer & $\begin{array}{l}\text { Goed gewas, gezonde } \\
\text { koeien, goed onderne- } \\
\text { mer, sociaal, divers }\end{array}$ & $\begin{array}{l}\text { Zorgt. Goede teelt en } \\
\text { goede ondernemer, } \\
\text { sociaal }\end{array}$ & Moet iedereen zelf weten & Heeft bedrijf in balans \\
\hline Goed land & $\begin{array}{l}\text { Goede opbrengst, } \\
\text { schoon, verzorgd, maar } \\
\text { hangt af van doel }\end{array}$ & $\begin{array}{l}\text { Strak en netjes, maar } \\
\text { hangt af van doel }\end{array}$ & $\begin{array}{l}\text { Geen onkruid, goede } \\
\text { opbrengst }\end{array}$ & $\begin{array}{l}\text { Strak groen, goede } \\
\text { afwatering, maar hangt } \\
\text { af van doel }\end{array}$ \\
\hline Rondrijden & $\begin{array}{l}\text { Doet iedereen, maar je } \\
\text { spreekt elkaar niet aan }\end{array}$ & $\begin{array}{l}\text { Doet iedereen, maar } \\
\text { je trekt toch je eigen } \\
\text { plan }\end{array}$ & Leven en laten leven & $\begin{array}{l}\text { Sociale controle, maar } \\
\text { daar trek je je niet veel } \\
\text { van aan }\end{array}$ \\
\hline Natuurinclusief & $\begin{array}{l}\text { Het landschap is hier } \\
\text { toch al kleinschalig }\end{array}$ & $\begin{array}{l}\text { Extensief (ruim } \\
\text { bouwplan) is beter }\end{array}$ & $\begin{array}{l}\text { We hebben die land- } \\
\text { schapselementen toch al }\end{array}$ & $\begin{array}{l}\text { Past bij dit gebied en de } \\
\text { boeren }\end{array}$ \\
\hline Thema's NIL & Patrijzenbeheer, hagen & $\begin{array}{l}\text { Plaagbestrijding, } \\
\text { bodemkwaliteit, } \\
\text { akkerranden }\end{array}$ & Houtwallen en singels & $\begin{array}{l}\text { Slootkanten, weidevo- } \\
\text { gels, kringlooplandbouw }\end{array}$ \\
\hline Leren & $\begin{array}{l}\text { Collectief, collega's, } \\
\text { ouders, studiegroep }\end{array}$ & $\begin{array}{l}\text { VvB, proefbedrijf, } \\
\text { collectief }\end{array}$ & $\begin{array}{l}\text { Collega's, stagiaires, } \\
\text { studiegroepen }\end{array}$ & $\begin{array}{l}\text { Studiegroepen, } \\
\text { collectief, collega's }\end{array}$ \\
\hline $\begin{array}{l}\text { Verandering in } \\
\text { denken/cultuur }\end{array}$ & $\begin{array}{l}\text { Minder spuiten, minder } \\
\text { bewondering voor } \\
\text { nieuwe stallen, onkruid } \\
\text { ligt minder gevoelig }\end{array}$ & $\begin{array}{l}\text { Natuur wordt leuker, } \\
\text { meer oog voor nuttige } \\
\text { insecten }\end{array}$ & & $\begin{array}{l}\text { Plas-dras wordt niet } \\
\text { meer raar gevonden, } \\
\text { vogeltjesland is ook } \\
\text { goed land, einde aan } \\
\text { groei }\end{array}$ \\
\hline
\end{tabular}

\section{Verandering in denken/cultuur}

De culturele norm in de verschillende casestudygebieden vertoont overeenkomsten en verschillen. $\mathrm{Er}$ is grote consensus over wat goed beheerd land is (geen onkruid, goede opbrengst) en dat oog voor de omgeving en de relatie met andere mensen en de maatschappij belangrijk is. In dat kader past ook het agrarisch natuurbeheer waar veel respondenten aan meedoen. Het overdragen van het bedrijf aan opvolgers is ook een motivatie om goed om te gaan met de grond en de bodem. Verschillen zijn er ook; de respondenten in Midden-Limburg zien dat er minder gewasbeschermingsmiddelen worden gebruikt en dat er minder bewondering is voor een nieuwe stal. In de Noordelijke Friese Wouden heeft men respect voor een boer met een hoge melkproductie, maar zelf streven ze daar niet naar. Ze vinden dat een kringloopboer ook een goede boer kan zijn. Tevens vinden ze voldoende vrije tijd en iets doen voor de maatschappij ook belangrijk. In Noord-Beveland zien ook enkele respondenten een kentering met betrekking tot de houding ten aanzien van natuur. Ze merken dat boeren meer interesse krijgen in natuurlijke plaagbestrijding en hoewel de norm nog gericht is op teelt en bestrijden van ziekten en plagen met gewasbeschermingsmiddelen, zijn er ook enkele respondenten die gerichter middelen toepassen. Men beseft dat gewasbeschermingsmiddelen ook het goede bodemleven kapot maken. De respondenten in de Achterhoek zien nog weinig verandering in het denken over de relatie landbouw-natuur. Ze onderhouden hagen en singels vooral omdat het noodzakelijk is. Een respondent vindt het grootschalig inzetten van glyfosaat een slecht gebruik.

\section{Natuurinclusieve landbouw}

De respondenten in Midden-Limburg, de Achterhoek en de Noordelijke Friese Wouden zien mogelijkheden voor natuurinclusieve landbouw, omdat het landschap waarin ze boeren hiervoor een geschikte uitgangspositie biedt. Het gaat in al deze gebieden om kleinschalige landschappen met landschapselementen, zoals houtwallen, singels en bosjes, of veel sloten. De meeste respondenten doen aan agrarisch natuurbeheer. Volgens de respondenten speelt in de Noordelijke Friese Wouden de vereniging de Noardlike Fryske Wâlden met 800 leden een belangrijke rol om landbouw te vervlechten met landschap, natuur en cultuurhistorie. De respondenten in dit gebied zijn vooral actief in weidevogelbeheer, botanisch beheer, onderhoud van houtsingels en het verbeteren van de bodem door minder kunstmest en bestrijdingsmiddelen. Ze proberen ook nieuwe dingen uit zoals het maken van bokashi (organische resten omzetten naar een bodemverbeteraar). In Midden-Limburg zijn patrijzenakkers en -randen 
populair en er zijn respondenten met een steenuilenkast, pakketten voor hoogstamboomgaarden of botanische akkerpakketten. Hier zien de boeren ook voordelen van natuur voor hun eigen bedrijf, met name in de vorm van bodemleven, natuurlijke vijanden, het winnen van natuurhooi en een combinatie met zorglandbouw. In de Achterhoek staan de respondenten niet afwijzend tegen natuurinclusief boeren, maar de druk op de grond in het gebied is hoog en dat bemoeilijkt een omschakeling. Men onderhoudt hagen, hakhoutbos en singels zowel met als zonder vergoeding en akkerrandenbeheer. In Noord-Beveland biedt het landschap geen geschikte uitgangspositie, omdat het grootschalige polders zijn waarin gelijksoortige akkerbouwbedrijven zorgen voor een monocultuur. De meeste respondenten in dit gebied doen echter wel aan agrarisch natuurbeheer bijvoorbeeld in de vorm van bloemrijke akkerranden. Ook houden ze rekening met de bodem door een extensief bouwplan te hanteren.

\section{Hoe boeren in de casestudy's zich indelen in niveaus van natuurinclusieve landbouw}

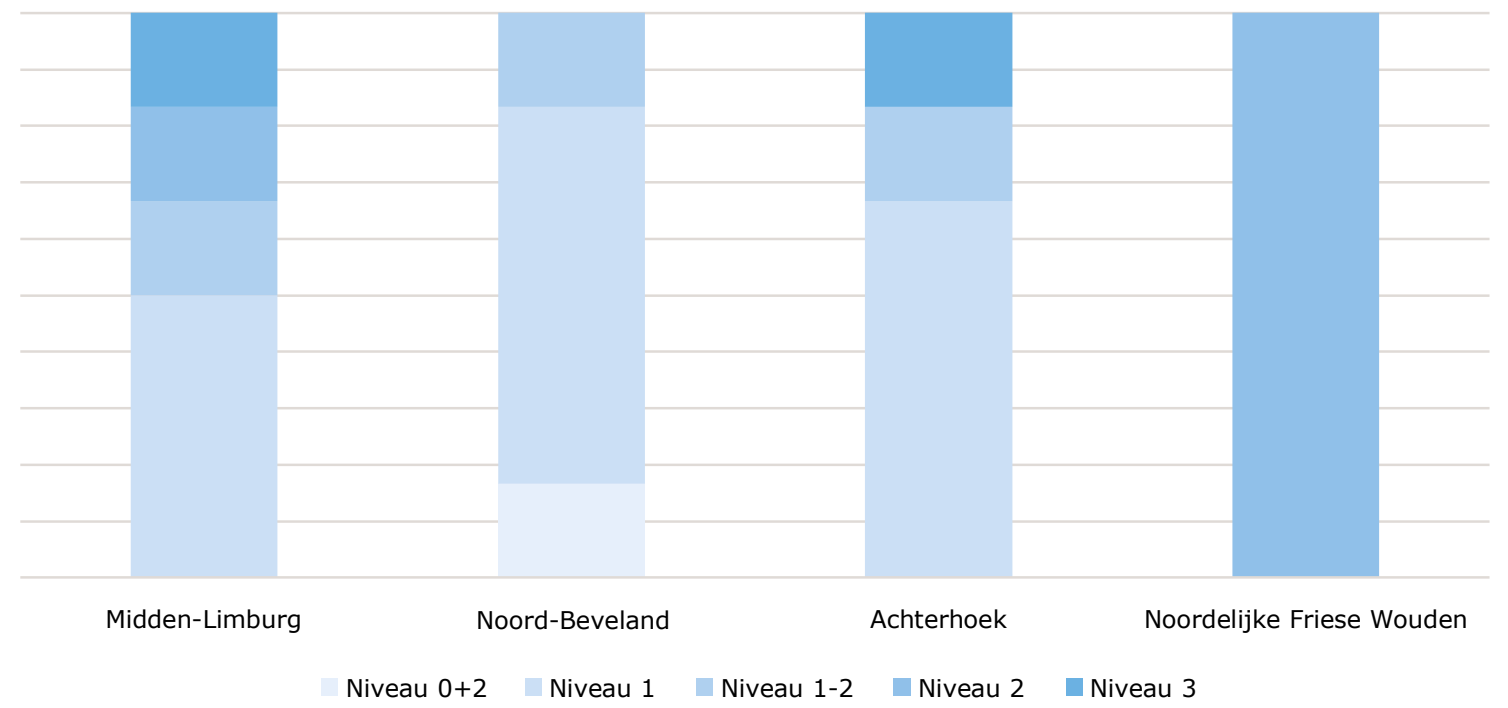

Figuur 3 Hoe de zes respondenten per casestudy zichzelf indelen met betrekking tot de niveaus in de Kamerbrief (zie paragraaf 1.1 )

De casestudy's verschillen in de niveaus van natuurinclusieve landbouw waarin de boeren zichzelf indelen (figuur 3). In de Noordelijke Friese Wouden is de groep het meest uniform: men doet aan agrarisch natuurbeheer en is bezig met kringlooplandbouw. In Noord-Beveland wordt akkerrandenbeheer door vier boeren gecombineerd met het verhogen van organische stof in de bodem en/ of natuurlijke plaagbestrijding. In de Achterhoek en in MiddenLimburg delen de meeste boeren zichzelf in bij agrarisch natuurbeheer, maar beide casestudy's hebben ook een boer die zichzelf in de meest natuurinclusieve categorie indeelt.

De variatie tussen regio's in de interpretaties van natuurinclusief is deels te verklaren uit de verschillende typen landschappen in de vier regiocasussen. De antwoorden hangen uiteraard samen met het type boeren dat is geïnterviewd: in Friesland zes veehouders in een weidegebied. Akkerrandenbeheer zal je dan hier niet zo snel tegenkomen. In Noord-Beveland daarentegen gaat het om zes akkerbouwers waarbij akkerrandenbeheer voor de hand ligt. In Midden-Limburg zijn zeer verschillende landbouwers geïnterviewd, wat past bij het landschap, en wat een breder beeld kan opleveren. In zowel de Noordelijke Friese Wouden als in de Achterhoek gaat het weliswaar om vijf melkveehouders en een gemengd bedrijf, maar in Friesland heeft men al vanuit de agrarische natuurverenigingen een verleden met natuur- en landschapsbeheer achter de rug die teruggaat tot de jaren 
negentig. Dat blijkt uit de natuurbewuste uitspraken die worden gedaan, terwijl onder de respondenten in de Achterhoek weinig intrinsieke motivatie voor natuur lijkt te bestaan.

De variatie binnen regio's lijkt vooral terug te voeren op het type boer en hoe deze zijn of haar bedrijf relateert aan de omgeving (bedrijfsstijl). Er is variatie onder de boeren in hoeverre landbouw wordt gezien als voedselproductie in een meer technisch beheerd systeem of als onderdeel van een levend ecosysteem. Wat de boer zelf onder natuur verstaat speelt dus ook een rol. Ook verschillen boeren in hoe belangrijk een hoge productie voor ze is en hoeveel affiniteit ze hebben met natuur. De groep Friese boeren lijkt uniform, maar verschillen toch aanzienlijk in onder meer de omvang van het bedrijf en de mate waarin ze aan verbreding doen. In de Achterhoek zijn vooral boeren van kleinschalige bedrijven geïnterviewd.

\subsubsection{Sociaal geconstrueerde verhalen}

De resultaten van de focusgroepen zijn verwerkt in de casestudybeschrijvingen. Focusgroepen geven echter naast inhoudelijke data ook informatie over hoe boeren op elkaar reageren in gesprek. In deze paragraaf lichten we specifiek verhalen uit die door de respondenten in de focusgroepen samen zijn geconstrueerd. We hebben dat geïdentificeerd als minimaal twee van de deelnemers elkaar in het gesprek bijvielen of aanvulden.

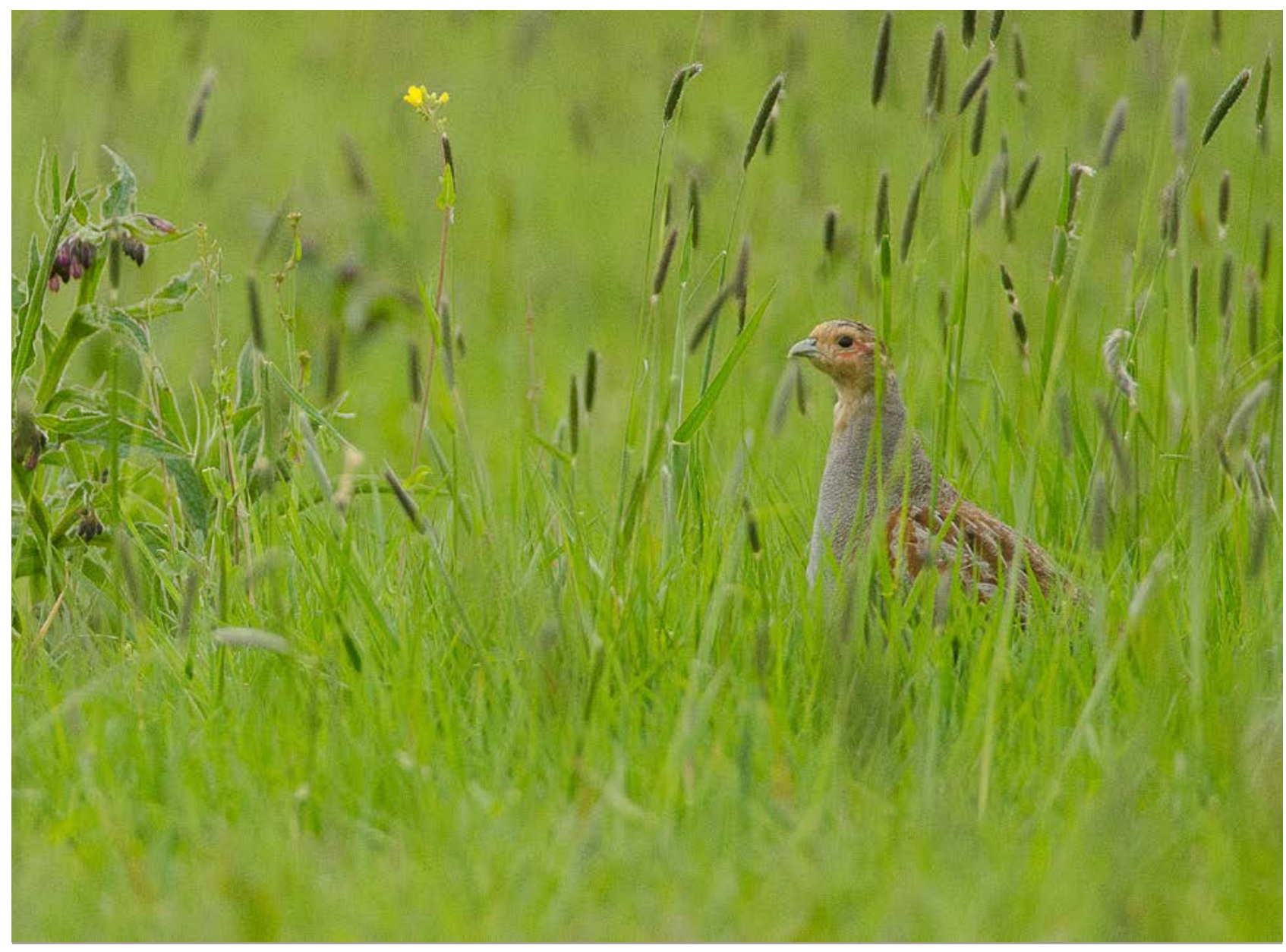




\section{Midden-Limburg}

- Er zijn verschillende soorten boeren en dat is prima. Je moet doen wat bij je past.

- Boeren die zelf dieren euthanaseren zijn slechte boeren.

- Extensiveren kan economisch slim zijn.

- Agrarisch natuurbeheer kan op kleine perceeltjes onderaan de streep meer geld opleveren dan maïs.

- Je kunt aan de buitenkant van het bedrijf niet zien wat de financiële situatie is.

- Boeren rijden rond om elkaars land en gewassen te beoordelen en bespreken wat ze zien met bekenden aan de keukentafel.

- De oudere generatie staat minder open voor natuur op het land, die wil nog overal oogstbaar gewas zien.

- Je bedrijfssysteem en de mogelijkheden van biologisch of NIL hangen sterk af van de grondsoort. Patrijzenbeheer past goed hier op de zandgrond.

- Er moet een financiële beloning tegenover staan om meer natuur op boerenland mogelijk te maken.

\section{Noord-Beveland}

- Een goede boer zorgt goed voor zijn land, zijn vee en zijn product en genereert een inkomen.

- Een slechte boer heeft jaar na jaar slechte gewassen of een zieke veestapel of direct water op het land als het regent.

- Er is in de maatschappij weinig oog voor de economische kant van het boerenbedrijf.

- Als je het bestrijden van onkruid goed bijhoudt, bespaar je kosten.

- Natuur wordt steeds leuker en mooier als je steeds meer akkerranden ziet.

- Dwang vanuit de overheid werkt averechts.

\section{Achterhoek}

- Een goede boer is goed voor mens, dier en milieu.

- Een slechte boer kun je herkennen aan het land en de veestapel.

- Sommige boeren lopen altijd op hun tenen en houden de schone schijn op om niet te laten blijken dat het slecht gaat.

- Je kunt de situatie van een ander nooit goed beoordelen. Aan de buitenkant kun je niet zien hoe het gaat. En iedereen heeft zijn eigen beeld bij hoe het moet zijn.

- Ieder bedrijf heeft sterke en zwakke punten, ieder doet het op zijn eigen manier.

- Lef is ook af en toe een pas op de plaats durven maken.

- In dit gebied laten mensen zich niet gek maken als iemand een nieuwe trekker heeft: doe maar gewoon dan doe je al gek genoeg.

- We hebben de handen vol aan het eigen bedrijf en trekken ons eigen plan, wat een ander daarvan vindt, doet er niet toe.

- In deze streek doe je al snel aan natuur met al die bomen en dat bos.

- Lange termijnafspraken zouden helpen bij het landschapsbeheer.

- Er staat teveel onkruid in de bermen. Vanwege de verkeersveiligheid gaan we dat zelf maaien.

- Staatsbosbeheer verwaarloost het land.

- Boeren krijgen veel minder geld voor natuurbeheer dan terreinbeherende organisaties.

- Kringlooplandbouw is niet haalbaar, dan moet er heel wat minder vee komen.

- Natuur is wel mooi, maar het is ook jammer als er goede grond wordt onttrokken aan de landbouw.

- Buren springen bij elkaar bij als het druk is.

- Er wordt selectief met de feiten omgegaan door bepaalde groepen. Wie het hardste schreeuwt, krijgt gelijk.

- GLB geld om natuurinclusief te worden is een sigaar uit eigen doos.

- Als de economie slecht draait, wordt de boer meer gewaardeerd.

- Ecologen hangen teveel aan vroeger, er komen nu gewoon andere soorten voor in de plaats.

- Het komt neer op een tegenstelling tussen stad en land. In de stad zit de meerderheid, de media en het geld. 


\section{Noordelijke Friese Wouden}

- Wat een goede boer is, hangt af van je perspectief. In ieder geval zorgt hij goed voor zijn vee. Hij is niet alleen gericht op het boeren, maar ook op de maatschappij.

- Status speelt onder de boeren geen rol, of je nu 30 of 200 koeien hebt maakt niet uit.

- Als jonge boer wil je het maximale van het land afhalen, maar dan moet er ook worden verdiend. Maar als je het mooi op de rit hebt, zijn er ook andere dingen die je kunt doen. Of als je partner een baan heeft.

- Je hoort steeds meer over natuur.

- Jongeren willen niet meer zo keihard werken.

- We zijn met de NFW met zijn allen in die richting ingeslagen, met al die collectieven in de buurt. Dat past ook weer bij de Wouden. We hebben met zijn allen gezegd we zijn iets anders bezig dan de rest van Nederland.

- In de Wouden werken we al natuurinclusief.

- Er is een grens aan de hoeveelheid gras van mindere kwaliteit dat je kunt inpassen.

- Het randenbeheer moet terugkomen: elke boer zou $10 \%$ van zijn land in natuur moeten zetten.

- Niet iedereen hoeft hetzelfde te doen: je zou als ondernemer wat meer vrijheid willen hebben. 
(2)

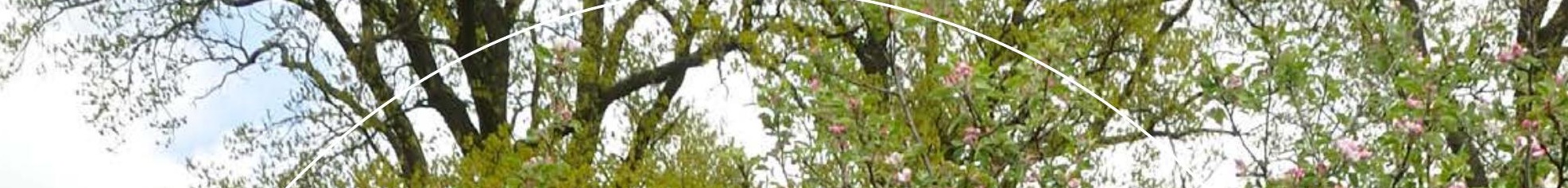
sing

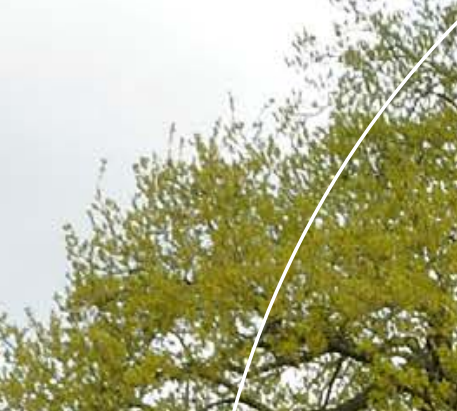

H.

sens

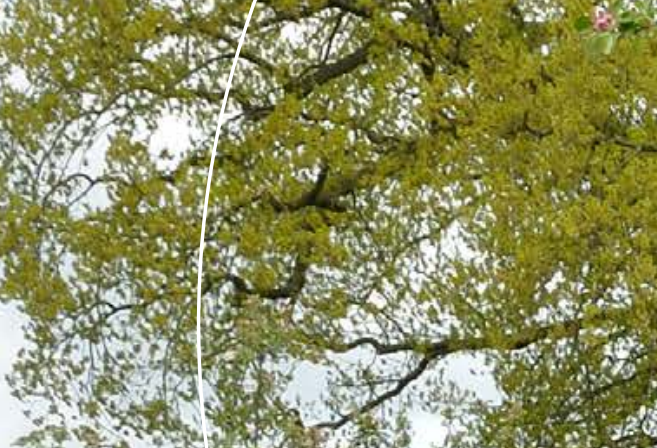

7.

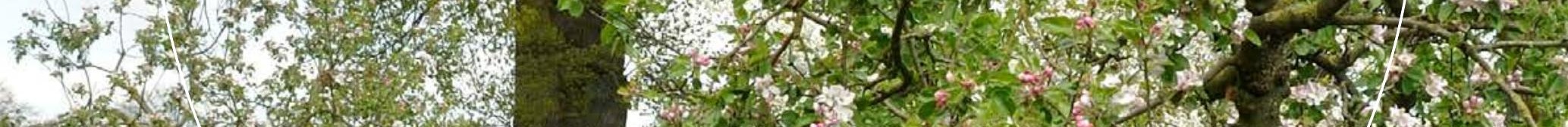

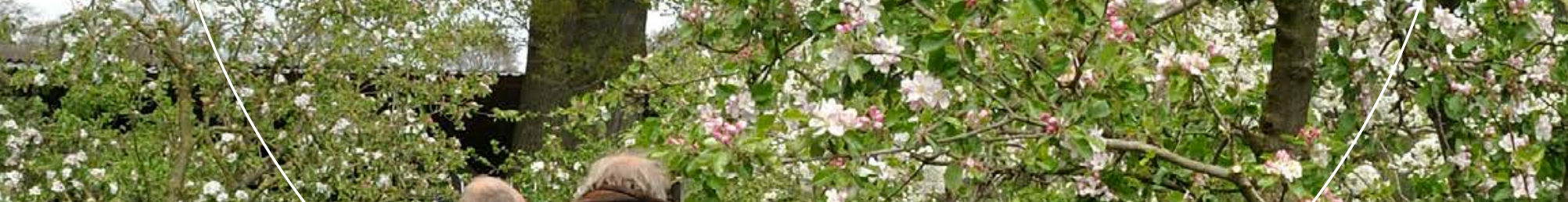

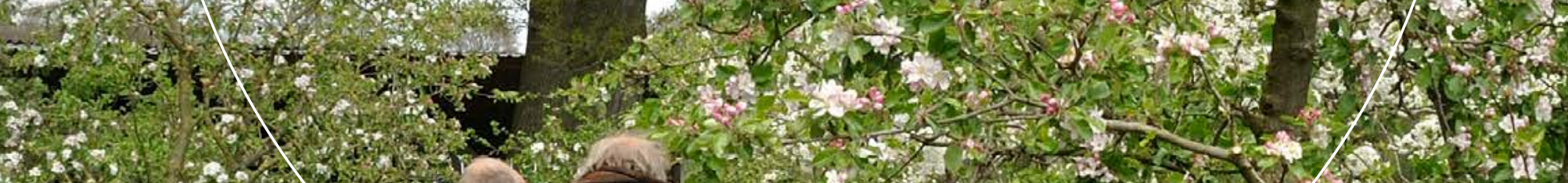

\section{(i)}

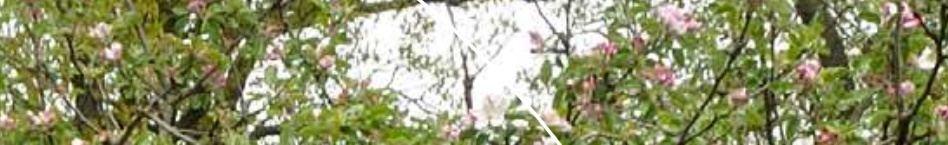
4.

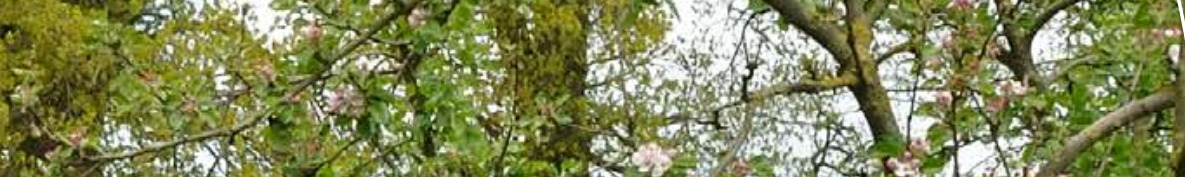
1.6.2.
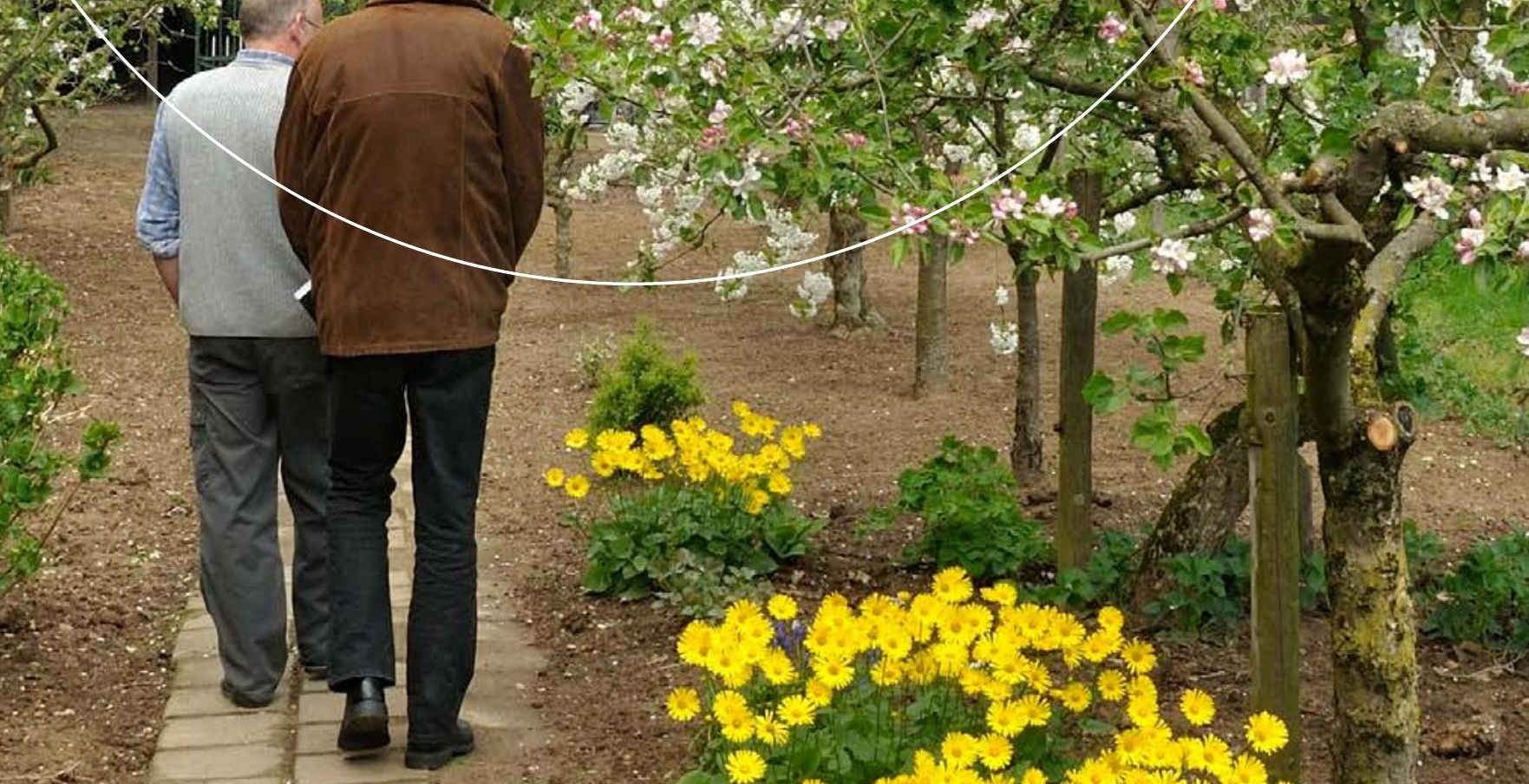

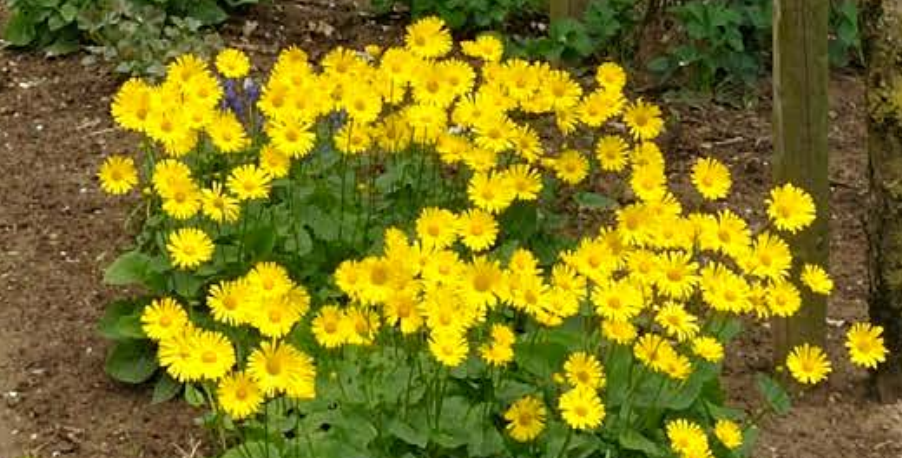




\section{4 Analyse}

In dit hoofdstuk stijgen we boven het niveau van de casestudy's uit en plaatsen we de bevindingen in het licht van het analytisch kader.

\subsection{Culturele normen en zelfidentiteit}

Bij de respondenten vonden we sterke overeenkomsten tussen hoe zij zichzelf beschrijven (zelfidentiteit) en wat zij beschrijven als 'goede boer'. De boeren worden niet geheel gedreven door culturele normen in hun omgeving: zelfidentiteit is ook heel belangrijk ('je probeert het voor jezelf zo goed mogelijk te doen'). Een deel van de respondenten zet zich af tegen (een deel van) de culturele normen die zij in hun gebied waarnemen, zoals de status die verleend wordt aan grote nieuwe stallen, of de reflex van akkerbouwers om te spuiten. Toch zien wij geen grote verschillen tussen de goede boer als culturele norm en de goede boer als zelfidentiteit.

Vanuit de casestudy's komt een vrij genuanceerd beeld naar boven van het beeld van een goede boer. In elk geval zorgt een goede boer goed voor het vee, het gewas en de bodem en levert een goed product. Er is wat discussie of een goede boer behalve de technische ook de economische kant van de bedrijfsvoering moet beheersen, maar over het algemeen vinden de respondenten het erbij horen. Ook worden (verstandig) ondernemerschap en willen innoveren en veranderen genoemd. Een hoge productie is niet per sé een kenmerk, maar een mooie oogst is wel een teken 'dat je op een goede manier bezig bent op je land'. Het is opvallend dat daarnaast (en vaak door dezelfde boeren) aspecten worden genoemd die te maken hebben met maatschappelijke verantwoordelijkheid, zorg voor het milieu en de natuur, sociaal gedrag, kwaliteit van leven (met name de verhouding tussen werktijd en vrije tijd), plezier in het werk, en zelfs geluk. Er is vrij veel begrip voor boeren met pech in de teelt of in financiële zin: iemand wordt pas een slechte boer genoemd als hij onethische dingen doet, zijn vee mishandelt en zijn bodem uitput.

Goed land is vooral productief land: netjes, egaal, strak, met rechte voren. Het vee, het erf en de bedrijfsgebouwen zien er goed verzorgd uit. Goed land heeft veel organische stof in de bodem. Onkruid en water op het land worden niet gewaardeerd. Maar als versterking van de biodiversiteit ook een doel is, mag het land er best anders uitzien. Boeren kunnen ook dan trots zijn op hun land en hun vakmanschap. De respondenten in NFW vonden dat ze beter in staat waren om graslanden voor weidevogels te realiseren dan Staatsbosbeheer (SBB). Dat concluderen ze op basis van hun constatering dat het SBB land veel pitrus heeft (een onkruid met een lage botanische- en voedingswaarde, en weinig waarde voor weidevogels). In Noord-Beveland had een van de deelnemers akkerranden, maar die moesten wel netjes zijn. De natuur moet dus nog steeds wel een beetje in toom worden gehouden.

$\mathrm{Er}$ is een duidelijke relatie tussen goed land en een goede boer. Net als in casussen in de literatuur beoordelen de boeren in onze vier Nederlandse casussen het vakmanschap van hun collega's op basis van wat ze zien: het landschap, het vee, de staat van het erf en de gebouwen. Daar komen nieuwe vormen van zichtbare informatie bij, zoals wat er te vinden is op de website van de Kamer van Koophandel, en benchmarking van bedrijfseconomische gegevens in studiegroepen. Ze maken ook de kanttekening dat niet alles aan de buitenkant zichtbaar is, waaronder de financiële situatie.

Aan de ene kant is duidelijk dat ook Nederlandse boeren rondjes rijden om elkaars land te beoordelen, en dat ze dat weten van elkaar, maar aan de andere kant zijn er weinigen die zeggen dat ze in hun keuzes rekening houden met wat hun collega's ervan vinden. Als ze dat wel doen, heeft het met onkruid te maken. Het is mogelijk dat ze 
niet graag toegeven dat ze rekening houden met de mening van anderen. Het is ook mogelijk dat de invloed van sociale controle beperkt is en boeren hun zelfidentiteit weinig spiegelen aan culturele normen. Het kan ook duiden op meerdere subculturen en een rol voor sociaal kapitaal (met welke groep identificeert de boer zich?) waardoor de ene mening zwaarder telt dan de andere. Sommige boeren houden niet alleen rekening met de mening van andere boeren over hun land, maar ook met die van burgers (bijvoorbeeld met betrekking tot het gebruik van glyfosaat).

In ons onderzoek benadrukken veel boeren liever hun individuele autonomie dan dat ze zich positioneren als uitdragers van een culturele norm. Toch wijken individuele boeren in hun beschrijving van 'de goede boer' en 'goed land' niet heel sterk af van het gezamenlijke beeld. Wel zetten sommigen zich af tegen een cultuur van negativiteit, veel te hard werken, een te groot geloof in schaalvergroting en onbekommerd glyfosaat gebruiken. We kunnen niet hard maken dat de culturele norm via de mening van (lokale) collega's een grote invloed heeft op de keuzes van boeren. Het lijkt erop dat de invloed van de culturele norm via de zelfidentiteit groter is (zie figuur 1 in paragraaf 2.2).

\subsection{Cultureel en symbolisch kapitaal in relatie tot economisch en sociaal kapitaal}

Uit de casestudy's blijkt een verband tussen belichaamd cultureel kapitaal (het vakmanschap van 'de goede boer') en geobjectiveerd cultureel kapitaal (met name het landschap). Het landschap is een zichtbare uitingsvorm van vakmanschap en er is vakmanschap en praktijkkennis nodig om dat in het landschap te herkennen en te waarderen. Natuurinclusief en natuurvriendelijk blijven doorgaans nog abstract voor respondenten. Er is veel kennis vereist om deze concepten te kunnen invullen. Het is duidelijk dat boeren moeten leren zien hoe 'goed natuurinclusief land' eruit ziet en dat ze bijvoorbeeld nog ervaring moeten opdoen met natuurlijke vijanden voordat ze het aandurven om minder te spuiten. Het missen van praktijkkennis over hoe lang je kunt wachten met een correctiemiddel is een drempel om te gaan experimenteren. Toch zien we dat een aantal boeren natuurinclusieve kennis aan het opbouwen is. Een boer die de waardplant van het pimpernelblauwtje herkent en waardeert, snapt de ecologie en weet waar hij het voor doet. En een boer die betrokken is geraakt bij ANLb, kan ook haagjes of patrijzenakkers bij anderen herkennen en waarderen. De kennis maakt ook dat respondenten het letterlijk anders zijn gaan zien, of zoals een respondent het verwoorde: "ik heb een andere bril gekocht." De kenmerken van het goede vakmanschap moeten inderdaad wel zichtbaar zijn om ze te kunnen herkennen: "een hectare zie je liggen maar anderen zien niet of je goed met natuurlijke vijanden weet te werken."

De combinatie van belichaamd en geobjectiveerd cultureel kapitaal levert symbolisch kapitaal op, in de vorm van meer of minder status in de boerengemeenschap. Zo werd in de Noord-Bevelandse groep nadrukkelijk negatief gesproken over een zekere collega, die van zijn land een zooitje had gemaakt.

In de casestudy's was weinig te vinden met betrekking tot geïnstitutionaliseerd cultureel kapitaal, zoals certificaten en diploma's. Indirect kunnen we zeggen dat de biologische boeren de beschikking hebben over geïnstitutionaliseerd cultureel kapitaal, al levert dit niet onder al hun collega's symbolisch kapitaal op. Dit heeft met subculturen te maken die elkaars symbolen niet altijd waarderen. Over certificaten en diploma's doen we desalniettemin een aantal aanbevelingen in 4.6.

Belichaamd cultureel kapitaal is beperkt overdraagbaar op anderen vanwege de tijdsinvestering die daarvoor nodig is. We zien daardoor inderdaad een grote invloed van de ouders op hun opvolgers. Een aantal van de jonge boeren in de casestudy's hield nadrukkelijk rekening met het beeld van goede landbouw zoals hun ouders dat zagen. Toch hebben de jonge boeren andere ideeën dan de vorige generatie. Opleiding en contact met anderen heeft immers ook invloed (Burton 2014). 
Boeren bouwen belichaamd cultureel kapitaal op door onder meer individueel en gezamenlijk leren. Bij individueel leren raadpleegt een boer zelf internet en vakliteratuur of reflecteert zij op haar eigen praktijkervaring. Daarnaast kan een boer leren door het observeren van de praktijk van haar collega's door middel van rondjes rijden. Bij gezamenlijk leren gaat het erom hoe boeren zich tot elkaar verhouden, bijvoorbeeld in een regio, en welke informele en formele mogelijkheden zij hebben om kennis met elkaar uit te wisselen. Daarbij zijn meerdere lijnen te onderscheiden: 1 ) het gezamenlijk leren in praktijknetwerken met kennisinstellingen, waarbij geleerd kan worden van elkaar, stagiaires en betrokken onderzoekers. 2) het gezamenlijk leren binnen agrarische natuurverenigingen door middel van voorlichting, bedrijfsbezoeken, het bespreken van praktijkervaringen en monitoringsresultaten en 3) het leren binnen de lijn van de keten van toeleverende en verwerkende industrie, ofwel de bedrijfsvoorlichting met alle commerciële adviseurs hier omheen (bedrijfsverenigingen en coöperaties). Binnen deze drie verschillende organisatievormen kunnen verschillende thema's gerelateerd aan natuurinclusieve landbouw aan de orde komen en kunnen de frequenties van activiteiten die hierop zijn gericht verschillen. Denk aan studiegroepen, bijeenkomsten voor het ontmoeten van collega's en deskundigen, en websites vanuit deze organisatielijnen. In Noord-Beveland hadden de Vereniging voor Bedrijfsvoorlichting en een proefboerderij een rol in de overdracht van vakmanschap. Een van de Midden-Limburgse boeren leerde veel in een benchmarkgroep. We zien dat met name de agrarische collectieven een rol spelen in de overdracht van vakmanschap op het gebied van agrarisch natuurbeheer, doordat boeren bij elkaar kunnen kijken en advies krijgen van de veldmedewerker. Hier wordt onder meer het belichaamd cultureel kapitaal opgebouwd dat nodig is om het geobjectiveerde cultureel kapitaal 'goed natuurinclusief land' te kunnen beoordelen.

We zien dus dat sociaal kapitaal ondersteunt bij het vormen van cultureel kapitaal in de vorm van sociaal leren. En hierboven zagen we al dat cultureel kapitaal sociaal kapitaal kan opleveren via symbolisch kapitaal. Dat is in lijn met de theorie van Bourdieu. Echter, de indruk ontstaat uit de onderzoeksresultaten dat de lokale boerengemeenschappen in de casestudy's niet (langer) heel hecht zijn³ (zie de subkopjes 'cultuur van samenwerken'). In Midden-Limburg legt een respondent uit: "Tegenwoordig die collega's die worden allemaal heel gespecialiseerd. De een heeft varkens, de ander heeft kippen, de ene heeft akkerbouw, ieder heeft zijn eigen straatje dus je hebt nog maar heel weinig gezamenlijke dingen natuurlijk." Daardoor heeft hij minder om met zijn lokale collega's te bespreken. Het sociaal kapitaal op Noord-Beveland lijkt het sterkst: hier is de sector nog redelijk uniform en het gaat ook nog eens om een eiland. Mogelijk is door toenemende specialisatie en afkalvend sociaal kapitaal in lokale boerengemeenschappen het effect van lokale sociale controle ('rondjes rijden') niet heel sterk en kunnen andere subculturen, zoals die van het agrarisch collectief, belangrijker worden.

Tot slot ligt er een relatie tussen economisch kapitaal en cultureel kapitaal. Een voorkeur voor productief ogend land lijkt te verklaren vanuit een 'taste of necessity', aangezien het inkomen van de boer en het voortbestaan van het boerenbedrijf afhangen van de opbrengst. Het inkomen is dan ook de door de respondenten meest genoemde drijfveer. En mogelijk hangt de relatief lage motivatie van de Achterhoekse respondenten voor biodiversiteit samen met het feit dat het vooral gaat om kleine bedrijven met een relatief zwakke economische positie. Boeren voor wie het economisch zwaarder is, hebben mogelijk minder psychologische ruimte om hun beeld van goede boer bij te stellen. Toch is inkomen niet het hele verhaal. Boeren doen ook uitspraken over dingen die ze gewoon mooi en leuk vinden, waar ze van kunnen genieten, die niet te relateren zijn aan productie. Die uitspraken gaan bijvoorbeeld over het boerenwerk, over het buiten zijn, over vogels en bloemen. Daarnaast vinden wij het wat te gemakkelijk om een voorkeur voor 'strak en netjes' geheel te koppelen aan productiviteit, zoals Sutherland (2013) doet. Heel veel mensen, niet alleen boeren, vinden regelmatige patronen netjes, overzichtelijk en mooi.

Een andere relatie tussen cultureel kapitaal en economisch kapitaal betreft de verkoopwaarde van het land. De respondenten doen regelmatig uitspraken in de zin van 'het land is daar veel te duur voor'. In de regel zijn in

3 Er komen steeds minder boeren en op het platteland nemen burgers hun plek in. Door diversiteit in bedrijfssystemen neemt de onderlinge vergelijkbaarheid af. Boeren zijn voor hun boerennetwerken minder afhankelijk geworden van lokale netwerken. En boeren hebben voor hun sociale leven meer keus dan alleen omgaan met andere boeren. 
berekeningen van vergoedingen voor agrarisch natuurbeheer grondkosten meegenomen. Desalniettemin vindt men de grond te waardevol om niet productief te laten zijn. In dezelfde lijn liggen uitspraken waarmee boeren aangeven dat ze 'minder courante grond' graag onderbrengen in het agrarisch natuurbeheer. Daarmee kunnen ze die toch zoveel mogelijk tot waarde brengen. Ook natuurbeheer 'moet immers iets opleveren', het is 'ook een teelt'. Dit komt overeen met de 'compenserende' redenen voor deelname aan een subsidieregeling voor agrarisch natuurbeheer zoals die was opgemerkt in Vlaams en Waals Brabant door Van Herzele et al. (2013). De nadruk op de economische waarde van de grond is in lijn met de theorie van Bourdieu. En de framing van natuurbeheer als een teelt past bij het pleidooi van Burton et al. (2008) om bij het bevorderen van biodiversiteit in termen van productie en resultaat aan te sluiten bij de denkwereld van boeren.

\subsection{Subculturen en bedrijfsstijlen}

Het bestaan van regionale subculturen was een aanname bij de opzet van dit onderzoek. Deze aanname wordt deels bevestigd, maar we kunnen slechts enkele vermoedens uiten ten aanzien van de aard van de verschillen. De respondenten in de Noordelijke Friese Wouden vinden zichzelf bijvoorbeeld anders dan de rest van Nederland door de historie en vooruitstrevendheid in het agrarisch natuurbeheer. De intrinsieke motivatie voor natuurinclusieve landbouw lijkt momenteel het hoogst in de Noordelijke Friese Wouden en in Midden-Limburg. In alle casestudy's zien respondenten dat alternatieven voor hoge productiviteit kunnen gelden als goede boer: in Friesland de kringloopboer, in de Achterhoek de kleine boer, in Noord-Beveland de extensieve boer, en in Midden-Limburg de rekenende natuurboer. In Noord-Beveland lijkt het sociaal kapitaal het sterkst, maar in de Noordelijke Friese Wouden zijn ze het meest trots op hun collectief. De Achterhoek is in meerdere opzichten een afwijkende casestudy. Onder meer heerst hier het sterkst een sfeer van leven en laten leven, terwijl de streek historisch gezien juist bekend staat om 'noaberschap'. We zien dat er cultuurverschillen zijn tussen de regio's, maar we kunnen ze niet duidelijk omschrijven vanwege de kleine steekproef en de grote diversiteit binnen de groepen respondenten.

Alle casestudy's laten een diversiteit tussen boeren zien. Ook de deelnemers zelf geven die diversiteit aan, die door de deelnemers in principe wordt gewaardeerd. 'Iedereen doet het op zijn eigen manier'. Het onderzoek was niet gericht op het maken van een overzicht van bedrijfsstijlen en het aantal respondenten is te beperkt om subculturen te kunnen identificeren. Toch kunnen we stellen dat de respondenten een diversiteit aan bedrijfsstijlen en subculturen vertegenwoordigen en zelf ook categorieën hanteren als het gaat om 'soorten boeren' waar ze zelf wel of niet bij horen. Met name in de Noordelijke Friese Wouden wordt gesproken in termen die overeenkomen met het denken in bedrijfsstijlen (wat niet vreemd is gezien de nauwe betrokkenheid van Van der Ploeg bij dit gebied).

Zo werd in Midden-Limburg onderscheid gemaakt tussen akkerbouwers en veehouders, met name in relatie tot hun kennis van en aandacht voor de bodem. In de Noordelijke Friese Wouden werden verschillende subculturen onderscheiden: kringloopboeren en topmelkers zijn goede boeren op basis van verschillende culturele normen. In NoordBeveland zijn er meerdere subculturen waar verschillende praktijken worden uitgewisseld: bijvoorbeeld die van de $\mathrm{V} v \mathrm{~B}$ met betrekking tot teelt en gewasbescherming en die van het agrarisch collectief met betrekking tot het agrarisch natuurbeheer.

Sommige respondenten zetten zich af tegen de heersende culturele norm wanneer die afwijkt van hun eigen beeld van een goede boer. Zo is er wrevel over schaalvergroting (NFW), het gebruik van glyfosaat (Achterhoek) en het neerzetten van dure nieuw stallen (Midden-Limburg). Dit soort spanningsvelden kan ertoe leiden dat de culturele norm wordt aangepast: het zorgt voor beweging in de culturele norm.

Het agrarisch natuurbeheer lijkt voor een subcultuur te hebben gezorgd waarbij boeren ervaring hebben opgebouwd met bepaalde vormen van beheer. Dit heeft hen kennis opgeleverd waarmee ze onder meer in staat zijn om vergelijkbaar beheer te herkennen en te waarderen op het land van andere boeren. 
Boeren hebben meerdere identiteiten en maken deel uit van meerdere subculturen. Een akkerbouwer in NoordBeveland die meedoet met agrarisch natuurbeheer maakt deel uit van een subcultuur van boeren die aan agrarisch natuurbeheer doen, en is tegelijkertijd onderdeel van de subcultuur van akkerbouwers op Noord-Beveland.

Boerensubculturen zijn lang niet meer alleen lokaal. Biologisch is bijvoorbeeld een landelijk netwerk. Een ander voorbeeld is het netwerk van Weidevogelboeren waarin boeren die zich sterk inzetten voor weidevogels elkaar opzoeken, mede omdat ze zich door hun lokale collega's niet gewaardeerd voelen en meer herkenning vinden bij elkaar (Runhaar and Polman, 2018). Een van de respondenten merkt op dat boeren tegenwoordig meer gespecialiseerd zijn en daarom minder met elkaar uitwisselen. Misschien heeft als gevolg daarvan de wetenschap dat collega's rondjes rijden niet zoveel invloed (meer) op de operationele beslissingen van de respondenten.

\subsection{Ontwikkeling en verandering van culturele normen}

De respondenten voor dit onderzoek zijn gezocht onder boeren die niet al vergaand natuurinclusief zijn, maar wel enige interesse hebben in natuur (zie 1.4). Hiermee hebben we in feite een bepaalde subcultuur onderzocht, waarbinnen ook weer spreiding en variatie bestaat. In deze subcultuur zien we dat het beeld van 'een goede boer' en 'een goed landschap' niet langer puur gericht is op productie (voor zover het ooit zo is geweest), maar dat onder meer (zorg voor) biodiversiteit daar onderdeel van kan zijn. Respondenten geven zelf aan dat ze de culturele normen zien veranderen. Ze zijn voorzichtiger geworden met het baseren van hun oordeel op wat ze zien: grote nieuwe stallen worden niet meer klakkeloos beschouwd als een teken van voorspoed. Onder akkerbouwers komt er steeds meer interesse in natuurlijke vijanden en bodemleven. En plas-dras is onder melkveehouders acceptabel geworden: "Zo ging het ook met plas-dras; in het begin dacht men die is gek, maar nu kijkt niemand er meer van op." Hier is sprake van een nieuwe praktijk die zichtbaar was in het landschap en die leidde tot verandering van de culturele norm doordat meer boeren het gingen doen.

Een culturele norm is bij uitstek sociaal geconstrueerd. Het is daarmee onvermijdelijk dat de culturele normen voor 'goede boer' en 'goed landschap' aan verandering onderhevig zijn. Verandering van culturele normen kan plaats vinden door de groei van bepaalde subculturen ten opzichte van andere en/of door de ontwikkeling van culturele normen binnen subculturen. Deze verandering gaat langzaam, onder meer vanwege de tijd die nodig is om belichaamd cultureel kapitaal op te bouwen en over te dragen.

\subsection{Kan een goede boer natuurinclusief zijn?}

Een goede boer zorgt goed voor land, vee en bodem, heeft ook de bedrijfseconomische kant van het boerenbedrijf op orde, gedraagt zich verantwoordelijk in relatie tot maatschappij en milieu, is sociaal en gelukkig en werkt niet te hard. Of deze culturele norm kansen of bedreigingen biedt voor natuurinclusieve landbouw hangt af van de precieze invulling van deze noties. Goed voor je land zorgen kan betekenen dat je landschapselementen beschermt, maar ook dat je het land volledig onkruidvrij houdt. Goed voor je vee zorgen kan betekenen dat je geen antibiotica gebruikt, of juist dat je ontwormt. Verantwoordelijkheid voor het milieu kan betekenen dat je kiest voor biologisch, maar kan ook gaan om een bewust gebruik van bestrijdingsmiddelen. Ondernemerschap kan gaan om zoveel mogelijk produceren, of juist om het slim inzetten van subsidies en kostenbesparing. Voor natuurinclusieve landbouw liggen er dus kansen in het gesprek over wat een goede boer is.

Een goede boer is herkenbaar aan zijn of haar land. Goed land is vooral strak, netjes, met rechte lijnen, zonder onkruid of waterplassen. Het meeste hiervan is geen goed nieuws voor natuurinclusieve landbouw, omdat het uitnodigt tot gebruik van chemische bestrijdingsmiddelen en weinig ruimte laat voor 'rommelige' en natte landschapselementen en kruiden die gunstig zijn voor biodiversiteit inclusief natuurlijke vijanden en bestuivers. Het 'nette landschap' biedt weinig mogelijkheden voor gebruik van bovengrondse ecosysteemdiensten in het landbouwsys- 
teem. Het willen vermijden van plassen op het land heeft echter - behalve een relatie met het gebruik van zware machines onder natte omstandigheden, wat een slechte boer zou doen - te maken met het gehalte aan organische stof in de bodem (dit is goed voor de bodemstructuur). De interesse van boeren in het verhogen van organische stof in de bodem sluit wel aan bij natuurinclusieve landbouw.

Ondanks dat natuurinclusieve landbouw niet geheel compatibel is met de huidige culturele normen in de landbouw zoals wij die in dit onderzoek en in de bestudeerde subcultuur hebben gevonden, laat het onderzoek wel diverse aanknopingspunten zien waarmee natuurinclusief voor meer boeren onderdeel kan worden van wat 'een goede boer' doet.

1 Landschap en cultuur in een regio spelen een rol. In Midden-Limburg, Noordelijke-Friese Wouden en de Achterhoek zeggen boeren dat natuurinclusieve landbouw bij het landschap past. Daarnaast zeggen de Friese boeren dat het past in hun cultuur. Dit komt overeen met de casestudy Eemland in het onderzoek van Westerink et al. (2018). In alle vier de casestudy's geven respondenten uitdrukking aan een verbinding met hun landschap. Deze verbinding kan een basis vormen voor het gesprek over het soort landbouw dat het eigen landschap versterkt.Goed land hangt af van de functie. Als biodiversiteit een doel is in combinatie met het produceren van voedsel, kan land er anders uitzien dan wanneer het alleen op productie is gericht. Het is belangrijk dat boeren zich bewust zijn van dat doel, erachter staan, en (leren) zien hoe hun handelen daaraan wel of niet bijdraagt.

2 'Natuurvriendelijke teelt is ook een teelt'. Daarmee wordt biodiversiteit ook een productiedoel, min of meer gelijkwaardig aan voedsel, waar het vakmanschap van de boer voor nodig is. Produceren, dat behoort immers tot het boerenvak. Van biodiversiteit een productiedoel maken, past bij de manier van denken van boeren.

3 Natuurinclusieve landbouw vraagt om een bepaald soort vakmanschap, dat niet vanzelfsprekend al aanwezig is. Sommige boeren geven aan behoefte te hebben aan de ontwikkeling van dergelijk vakmanschap ('nu kan ik kunstmest en antibiotica nog niet missen'). Daarvoor moeten boeren dan wel de gelegenheid krijgen.

4 Ook het herkennen van de zichtbare aspecten van natuurinclusieve praktijken bij anderen vraagt een bepaald soort vakmanschap. Sommige boeren hebben door het meedoen met agrarisch natuurbeheer 'een nieuwe bril gekocht' waarmee ze anders naar het land van hun collega's kijken.

5 Het zien van resultaten van het natuurbeheer werkt stimulerend. Het is een vorm van feedback op en bevestiging van het eigen vakmanschap. Als dit een zichtbare vorm kan krijgen, kunnen deze resultaten ook een rol hebben in het tentoonspreiden van dergelijk vakmanschap aan collega-boeren.

6 Diverse respondenten geven aan plezier te beleven aan natuur op hun bedrijf, bijvoorbeeld in de vorm van wilde planten en vogels. Een aantal van hen is natuur steeds meer gaan waarderen doordat ze ervaring opdeden met agrarisch natuurbeheer. Als er affiniteit is met natuur, hoeft er geen groot conflict te zijn met de zelfidentiteit van een goede boer. Veel boeren genieten van het buiten zijn en daar kan het waarnemen van wilde planten en dieren deel van uitmaken.

7 Als boeren vinden dat ze betere natuurbeheerders zijn dan terreinbeherende organisaties (bijvoorbeeld in het geval van weidevogelbeheer), is natuurbeheer blijkbaar onderdeel van het vakmanschap van 'een goede boer' en valt er onder boeren 'eer aan te behalen'.

8 Een goede boer zorgt goed voor de bodem. Diverse respondenten hebben interesse in het verhogen van het gehalte aan organische stof. Onder met name akkerbouwers is er interesse in natuurlijke plaagbestrijding. Daaruit blijkt behoefte aan kennis over ecosysteemdiensten en de biodiversiteit die daarvoor nodig is. 
9 Onder de respondenten is er waardering voor diversiteit onder boeren. Zo kunnen er meerdere typen 'goede boeren' zijn en kan er ook respect zijn voor natuurinclusieve boeren.

10 Het respect voor ondernemerschap onder boeren kan een argument vormen voor natuurinclusieve landbouw. Door de vergoedingen voor agrarisch natuurbeheer en de lage natuurpacht kan natuurbeheer onderdeel zijn van goed ondernemer- en koopmanschap, als de inkomsten opwegen tegen de kosten. Daarnaast is de relatieve zekerheid van natuurvergoeding prettig bij alle onzekerheid ten aanzien van weer, opbrengsten en marktprijzen. Ook extensivering kan economisch slim zijn, als lagere kosten de lagere opbrengsten compenseren en bijvoorbeeld de bodemkwaliteit erdoor op orde blijft. Niet alle boeren maken het rekensommetje. Zoals bleek in de Limburgse focusgroep kan een rekensommetje echter zeer overtuigend zijn.

11 De agrarische collectieven hebben een duidelijke rol in het faciliteren van leren tussen boeren. Ze geven advies over agrarisch natuurbeheer, begeleiden het in de praktijk brengen en daarmee het zichtbaar maken daarvan, creëren zo een subcultuur waarin natuurinclusief vakmanschap kan worden ontwikkeld en gewaardeerd, en leren hun deelnemers natuurinclusieve praktijken te herkennen bij anderen. Daarmee spelen ze een belangrijke rol in het beïnvloeden van de culturele normen ten aanzien van 'goede boer' en 'goed landschap'.

12 De invloed van andere partijen, zoals Friesland-Campina en burgers, zet boeren aan het denken over landbouw in relatie tot biodiversiteit. Waar sommige respondenten nog twijfelen of zij zonder gewasbeschermingsmiddelen of ziektebestrijders kunnen, verwachten de boeren dat dit wel straks 'het nieuwe normaal' wordt omdat de maatschappij erom vraagt. Menig boer doet de burger graag een plezier. Waardering van recreanten voor het landschap en de inspanningen van de boer betekent erkenning. Dat andere partijen invloed kunnen hebben op het beeld van 'goed landschap' kwam eerder ook uit het onderzoek van De Krom (2017).

Net als in relatie tot 'de goede boer' bestaan in relatie tot natuurinclusieve landbouw verschillende beelden onder boeren. In dit onderzoek interpreteren de respondenten in de vier regio's natuur en natuurinclusief zowel smal als breed. Het kan gaan om het verbeteren van biodiversiteit in termen van algemene of bijzondere soorten flora en fauna. Ook minder belasting van het milieu en verbetering van bodemkwaliteit worden aangemerkt als natuurinclusief. Verder is ook de verhoging van de belevingswaarde van het agrarisch landschap door boeren genoemd als natuurinclusief. De verschillende accenten in de interpretatie van natuurinclusieve landbouw komen overeen met de bedoeling van het beleidsconcept: verschillende vormen van natuurinclusieve landbouw moeten perspectief bieden voor een breed scala aan boeren. De breedte in beide concepten (goede boer en natuurinclusief) kan gunstig zijn: dit maakt het voor veel boeren mogelijk om overeenkomsten te vinden en natuurinclusief in te passen in een beeld van goede boer. Aan de andere kant is er ook altijd een reden om er niet mee aan de slag te gaan.

\subsection{Handelingsperspectief}

Hoe is dit alles relevant voor overheden en anderen, zoals de agrarische collectieven, die zoeken naar mogelijkheden om beslissingen van boeren ten aanzien van hun bedrijfsvoering te beïnvloeden? Ten eerste geven het theoretisch kader en de onderzoeksresultaten veel inzicht in hoe het komt dat bijvoorbeeld regelingen voor agrarisch natuurbeheer niet alle boeren aanspreken. Regels en subsidies leiden niet zonder meer tot het gewenste gedrag: culturele normen en zelfidentiteit kunnen ook een belangrijke rol spelen bij de uiteindelijke keuzes van boeren. Een tegenstelling tussen beelden van 'goede boer' en 'goed landschap' en natuurinclusieve landbouw kan de drempel voor boeren hoog maken om hun bedrijf in die richting te ontwikkelen, zelfs als er vergoedingen tegenover staan. 
Ten tweede kunnen de opgedane inzichten gebruikt worden om beleid te ontwerpen dat beter aansluit bij de cultuur in boerengemeenschappen of zelfs bijdraagt aan de verandering daarvan. Dit moet wel met respect en bescheidenheid gebeuren. Culturele normen zijn niet maakbaar. Beïnvloeding is wel mogelijk. Bescheiden interventies op de korte termijn kunnen effect hebben op de cultuur op de lange termijn.

\section{Kader 3: Prestatiebetalingen}

Subsidieregelingen voor agrarisch natuurbeheer zijn in Nederland en in de rest van Europa in de regel ingericht op basis van betaling voor inspanningen. Bijvoorbeeld voor het aanleggen en onderhouden van een akkerrand. Op diverse plekken in Europa wordt inmiddels ook geëxperimenteerd met betaling voor resultaat. Bijvoorbeeld voor het aantal insectensoorten dat op een akker wordt aangetroffen. Betaling voor resultaat in plaats van voor inspanning heeft volgens de huidige ervaringen en in relatie tot gedragsinzichten onder meer de volgende voordelen (Burton and Schwarz, 2013; Fleury et al., 2015; Keenleyside et al., 2014):

- Afspraken over te behalen resultaten laten de boer vrij in de manier waarop de resultaten worden behaald;

- Dit past bij de voorkeur voor autonomie bij boeren en doet een beroep op zijn of haar vakmanschap en creativiteit;

- Betaling voor prestaties prikkelt de boer om kennis te ontwikkelen met betrekking tot de biodiversiteit die wordt nagestreefd, en daarvoor gunstige condities (o.a. beheer);

- Het wekt interesse bij de boer in monitoring en monitoringsresultaten;

- Het biedt mogelijkheden om te laten zien dat hij of zij het beter doet dan andere deelnemers: een competitief element kan de ambitie verhogen;

- De opgebouwde kennis en succeservaringen verhogen de motivatie en de betrokkenheid bij natuur.

Uiteraard zijn er ook nadelen aan prestatiebetalingen, waaronder het risico dat boeren lopen als ze weinig grip hebben op de afgesproken resultaten (bijvoorbeeld in het geval van predatie van weidevogels). Veel hangt af van de gekozen indicatoren en de organisatievorm (bijvoorbeeld al dan niet collectief). De Europese Commissie is van plan om het GLB als geheel meer te baseren op prestaties van boeren. Het is te verwachten dat prestatiebetalingen ook in het agrarisch natuurbeheer terrein gaan winnen.

Op basis van ons onderzoek komen wij tot de volgende aanbevelingen:

1 Frame biodiversiteit in termen van productie of prestatie

a. Experimenteer met resultaatsbetalingen (zie kader 3). Dit maakt van natuur voor de boer een productiedoel, waar natuurinclusief vakmanschap voor nodig is. Boeren zijn gewend om in termen van productie te denken.

b. Maak inzichtelijk dat natuurbeheer, extensivering, het kleiner maken van kringlopen, duurzaam bodembeheer en het gebruik maken van ecosysteemdiensten economisch slim kunnen zijn: maak rekenvoorbeelden beschikbaar. Bied continuïteit in (subsidie-) regelingen.

2 Maak natuurinclusief vakmanschap zichtbaar voor andere boeren

a. Identificeer uitingen van natuurinclusief vakmanschap die zichtbaar zijn of zichtbaar zijn te maken, zoals plas-dras of brede akkerrand (zichtbaar in landschap) en aantallen weidevogels (zichtbaar op website). Ontwikkel indicatoren voor natuurinclusieve landbouw waar boeren zich mee kunnen vertonen.

b. Toon uitingen van natuurinclusief vakmanschap, bijvoorbeeld door middel van bebording, informatie op internet of bespreking tijdens bijeenkomsten.

c. Maak monitoring en het publiceren van monitoringsresultaten mogelijk, om vooruitgang te kunnen laten zien en om ervan te kunnen leren.

d. Organiseer benchmarking tussen boeren onderling, die hun (monitorings-) gegevens uitwisselen, waardoor zichtbaar wordt wie er goed in is, er wedstrijdjes ontstaan, en ervaringen en lessen kunnen worden uitgewisseld.

3 Bevorder de opbouw van natuurinclusief vakmanschap

a. Versterk de rol van de agrarische collectieven en andere boerenorganisaties in het introduceren van natuurinclusieve praktijken, de opbouw van natuurinclusief vakmanschap en het onderling leren.

b. Maak het mogelijk dat boeren kunnen experimenteren met natuurinclusieve praktijken. 
c. Zorg voor opleidingen die bijdragen aan natuurinclusief cultureel kapitaal en voor diploma's, certificaten en prijzen die formele erkenning geven aan natuurinclusief vakmanschap.

4 Bevorder de ontwikkeling van natuurinclusieve subculturen

a. Houd rekening met en faciliteer diversiteit tussen (verduurzamende) boeren, ook binnen subculturen.

b. Faciliteer studiegroepen, collectieven etc. die willen werken aan natuurinclusieve landbouw. Dit verlaagt de drempel voor boeren om deel te worden van een andere dan hun huidige subcultuur, en maakt het mogelijk dat boeren zelf en samen bouwen aan natuurinclusieve culturele normen.

c. Faciliteer meer contact en samenwerking tussen boeren en burgers.

d. Maak gebruik van regionale verschillen in landschap, cultuur en sectoren.

e. Zet lokale kennis in/ mensen die de beoogde subculturen van binnenuit kennen en daarop invloed kunnen uitoefenen.

In tabel 2 is expliciet gemaakt voor welke partijen de aanbevelingen van toepassing kunnen zijn.

Tabel 2: Aanbevelingen voor het bevorderen van natuurinclusieve culturele normen in de landbouw

\begin{tabular}{|c|c|c|c|c|c|}
\hline \multicolumn{2}{|c|}{ Aanbeveling } & \multirow{2}{*}{$\begin{array}{l}\text { Overheid } \\
\qquad \sqrt{ }\end{array}$} & \multirow{2}{*}{$\begin{array}{c}\text { Boeren- } \\
\text { organisaties } \\
\qquad \sqrt{ }\end{array}$} & \multirow{2}{*}{$\begin{array}{c}\text { Maatschappelijke } \\
\text { organisaties } \\
\sqrt{ }\end{array}$} & \multirow{2}{*}{$\begin{array}{c}\text { Ketenpartijen } \\
\qquad \sqrt{ }\end{array}$} \\
\hline 1 & $\begin{array}{l}\text { Frame biodiversiteit in termen van productie of } \\
\text { prestatie }\end{array}$ & & & & \\
\hline & a. Experimenteer met resultaatsbetalingen & $\sqrt{ }$ & $\sqrt{ }$ & $\sqrt{ }$ & $\sqrt{ }$ \\
\hline & $\begin{array}{l}\text { b. Maak rekenvoorbeelden beschikbaar. } \\
\text { Bied continuïteit in (subsidie)regelingen. }\end{array}$ & $\begin{array}{l}\sqrt{ } \\
\sqrt{ }\end{array}$ & $\sqrt{ }$ & $\sqrt{ }$ & $\begin{array}{l}\sqrt{ } \\
\sqrt{ }\end{array}$ \\
\hline \multirow[t]{5}{*}{2} & $\begin{array}{l}\text { Maak natuurinclusief vakmanschap zichtbaar voor } \\
\text { andere boeren }\end{array}$ & $\sqrt{ }$ & $\sqrt{ }$ & $\sqrt{ }$ & $\sqrt{ }$ \\
\hline & $\begin{array}{l}\text { a. Identificeer zichtbare uitingen van natuurinclusief } \\
\text { vakmanschap }\end{array}$ & $\sqrt{ }$ & $\sqrt{ }$ & $\sqrt{ }$ & $\sqrt{ }$ \\
\hline & b. Toon uitingen van natuurinclusief vakmanschap. & $\sqrt{ }$ & $\sqrt{ }$ & $\sqrt{ }$ & $\sqrt{ }$ \\
\hline & $\begin{array}{l}\text { c. Maak monitoring en het publiceren van monito- } \\
\text { ringsresultaten mogelijk. }\end{array}$ & $\sqrt{ }$ & $\sqrt{ }$ & $\sqrt{ }$ & $\sqrt{ }$ \\
\hline & d. Organiseer benchmarking tussen boeren. & $\sqrt{ }$ & $\sqrt{ }$ & $\sqrt{ }$ & $\sqrt{ }$ \\
\hline \multirow[t]{4}{*}{3} & Bevorder de opbouw van natuurinclusief vakmanschap & $\sqrt{ }$ & $\sqrt{ }$ & & \\
\hline & a. Versterk de rol van de agrarische collectieven. & $\sqrt{ }$ & & $\sqrt{ }$ & \\
\hline & b. Maak experimenten mogelijk. & $\sqrt{ }$ & & & $\sqrt{ }$ \\
\hline & $\begin{array}{l}\text { c. Zorg voor opleidingen, diploma's, certificaten en } \\
\text { prijzen. }\end{array}$ & $\sqrt{ }$ & & $\sqrt{ }$ & \\
\hline \multirow[t]{6}{*}{4} & $\begin{array}{l}\text { Bevorder de ontwikkeling van natuurinclusieve } \\
\text { subculturen }\end{array}$ & $\sqrt{ }$ & $\sqrt{ }$ & & \\
\hline & a. Houd rekening met en faciliteer diversiteit. & $\sqrt{ }$ & & $\sqrt{ }$ & $\sqrt{ }$ \\
\hline & b. Faciliteer studiegroepen, collectieven etc. & $\sqrt{ }$ & $\sqrt{ }$ & & \\
\hline & c. Faciliteer contact tussen boeren en burgers. & $\sqrt{ }$ & $\sqrt{ }$ & $\sqrt{ }$ & $\sqrt{ }$ \\
\hline & d. Maak gebruik van regionale verschillen. & $\sqrt{ }$ & & & $\sqrt{ }$ \\
\hline & e. Zet lokale kennis in. & $\sqrt{ }$ & $\sqrt{ }$ & $\sqrt{ }$ & \\
\hline
\end{tabular}


In dit hoofdstuk beantwoorden we de onderzoeksvragen.

\section{Wat is een goede boer volgens boeren?}

Een goede boer zorgt goed voor land, vee en bodem, heeft ook de bedrijfseconomische kant van het boerenbedrijf op orde, gedraagt zich verantwoordelijk in relatie tot maatschappij en milieu, is sociaal en gelukkig en werkt niet te hard. Een goede boer is herkenbaar aan zijn of haar land. Het beeld van een 'goede boer' is echter niet uniform: agrarische subculturen geven er hun eigen invulling aan en dat geldt ook voor iedere individuele boer.

\section{Aan welk landschap herkennen boeren een goede boer?}

Het landschap is voor boeren een plek om hun identiteit als boer te uiten en hun vakmanschap te laten zien. Hun beroepstrots houdt ten eerste verband met het verdienen van een inkomen door middel van het produceren van voedsel. Daarom hebben boeren de meeste waardering voor geordend, onkruidvrij land met egaal gewas en gezond vee. Natuur kan een nevendoel zijn. Land dat ook biodiversiteit moet opleveren, mag er in de ogen van onze respondenten anders uitzien dan land dat alleen voor voedselproductie is bedoeld. Dit land kan evengoed een uiting zijn van goed vakmanschap.

\section{Welke rol spelen deze culturele normen en het oordeel van collega's bij keuzes van boeren met} betrekking tot hun bedrijfsvoering?

Boeren rijden rond in hun omgeving om het land van hun collega's te beoordelen en ze weten dat van elkaar. Onkruid en waterplassen op het land, met name, zijn zichtbare tekenen dat een boer zijn vak niet verstaat, en kunnen leiden tot verlies van status van een boer onder zijn collega's. Toch zeggen onze respondenten nauwelijks rekening te houden met het oordeel van hun rondrijdende collega's bij de keuzes die ze maken ten aanzien van de bedrijfsvoering. Het is vooral hun eigen beeld van een 'goede boer' en 'goed land' dat hen leidt in dergelijke beslissingen. Mogelijk dat de lokale subcultuur aan invloed verliest door toenemende specialisatie en doordat boeren ook deel uitmaken van regionale en nationale (sectorale) subculturen. Want boeren meten hun zelfidentiteit als goede boer wel degelijk af aan een culturele norm, soms door zich ertegen af te zetten.

\section{In hoeverre is 'natuurinclusief' verenigbaar met het beeld van een 'goede boer' en een 'goed} landschap'?

In de internationale literatuur worden culturele normen met betrekking tot 'goede boer' en 'goed landschap' gezien als barrières voor een brede deelname in agrarisch natuurbeheer of biologische landbouw ${ }^{4}$ Het beeld van een 'goede boer' dat uit ons onderzoek komt, kan afhankelijk van de invulling positief of negatief uitvallen voor natuurinclusieve landbouw. Het is vooral de koppeling met het beeld van 'goed land' dat laat zien dat natuurinclusief niet zonder meer goed aansluit bij de culturele normen. Toch zijn er diverse aanknopingspunten die laten zien hoe natuurinclusief toch onderdeel kan zijn van 'goede landbouw', of dat kan worden. Belangrijke aanknopingspunten zijn het benoemen van biodiversiteit als een productiedoel of teelt, en de behoefte onder boeren om vakmanschap te ontwikkelen ten aanzien van bijvoorbeeld agrarisch natuurbeheer en natuurlijke plaagbestrijding.

4 Aangezien natuurinclusieve landbouw een puur Nederlands concept is, moest in de literatuur breder worden gekeken naar vergelijkbare overwegingen van boeren. 
5 Is er sprake van verandering van deze culturele normen, en van subculturen? Verschillen culturele normen per gebied?

Een aantal van onze respondent benoemt veranderingen in denken bij henzelf of in de sector ten aanzien van culturele normen. Vaak is die verandering het gevolg van eigen ervaring met agrarisch natuurbeheer of van het zien in het landschap van agrarisch natuurbeheerpraktijken bij anderen. Daardoor leren ze anders naar het landschap te kijken. De agrarische collectieven voor agrarisch natuurbeheer zijn een voorbeeld van subculturen waarin natuurinclusief een goede vorm van landbouw kan zijn, en waarin het vakmanschap wordt ontwikkeld dat nodig is om natuurinclusief in de praktijk te brengen en om het te herkennen op het land van anderen.

In sommige regio's lijken boeren meer open te staan voor natuurinclusieve landbouw dan in andere. Ook verschilt de praktische uitwerking van natuurinclusieve landbouw in verschillende landschappen en sectoren. Een gebiedsgerichte benadering is zinvol, zonder daarbij uit het oog te verliezen dat de diversiteit tussen boeren binnen gebieden groot is, en hun subculturen niet alleen gebiedsgebonden zijn.

\section{Hoe zijn deze inzichten te vertalen naar mogelijkheden voor sturing?}

Inzicht in de rol van culturele normen in de landbouw levert een aantal aanknopingspunten op voor het ondersteunen van een bredere beweging richting natuurinclusieve landbouw (in 4.6 zijn deze verder uitgewerkt):

1. Het framen van biodiversiteit in termen van productie of prestatie

2. Het zichtbaar maken van natuurinclusief vakmanschap voor andere boeren

3. Het bevorderen van de opbouw van natuurinclusief vakmanschap

4. Het bevorderen van de ontwikkeling van natuurinclusieve subculturen

Kan een goede boer natuurinclusief zijn? Ja, dat kan, binnen een nu nog beperkte subcultuur waarin natuurinclusieve landbouw verenigbaar is met culturele normen voor 'goede boer' en 'goed landschap'. Natuurinclusieve landbouw kan voor meer boeren een passende optie worden als natuurinclusieve subculturen in omvang toenemen en als natuurinclusieve culturele normen meer onderdeel worden van andere subculturen.

Verder onderzoek zou zich kunnen richten op:

- Factoren die een rol spelen bij de keuzes van jonge boeren ten aanzien van natuurinclusieve landbouw, inclusief culturele normen.

- Een kwalitatieve en kwantitatieve studie naar de afbakening en omvang van subculturen of bedrijfsstijlen.

- De invloed van de publieke opinie en actoren buiten de landbouw op culturele normen binnen de landbouw, bijvoorbeeld via de niet-agrarische subculturen waar boeren ook deel van uitmaken.

- De rol van ketenpartijen in de ontwikkeling van culturele normen in de landbouw. 


\section{Discussie}

\subsection{Beperkingen van het onderzoek}

Dit onderzoek zegt niet alles over keuzes van boeren ten aanzien van natuurinclusieve landbouw. We hebben alleen gekeken naar culturele normen in de landbouw met betrekking tot 'goede boer' en 'goed landschap'. Bijlage 1 maakt duidelijk dat het scala aan factoren die meewegen in de keuzes van boeren veel breder is. Hoewel in ons onderzoek respondenten wel uitspraken hebben gedaan over bijvoorbeeld bedrijfseconomische factoren, de ligging van het bedrijf ten opzichte van natuurgebieden, regelgeving en markt, had dat niet de focus van ons onderzoek.

Ook zegt dit onderzoek niet alles over de rol van culturele normen. We hebben niet de natuurinclusieve koplopers onderzocht en ook geen boeren bevraagd die niet bereid zijn om bovenwettelijke inspanningen te doen voor biodiversiteit of daar zelfs actief tegenstander van zijn. We kunnen niets zeggen over de omvang van een 'natuurinclusieve subcultuur' omdat wij kwalitatief onderzoek hebben gedaan met 'slechts' vier casestudy's en 24 boeren. Ons onderzoek is rijk in kwalitatieve data, maar is niet representatief. We hebben geen gegevens verzameld waarmee de respondenten kunnen worden vergeleken met bestaande typeringen. Daarmee kunnen we slechts beperkt uitspraken doen over culturele normen in 'de' landbouw. Toch denken wij dat de casestudy's bij velen veel herkenning zullen oproepen. Kwantitatief onderzoek naar culturele normen zou een mooie aanvulling zijn op dit onderzoek.

Ook had ons onderzoek weinig aandacht voor de invloed van publieke opinie, erfbetreders etc. op culturele normen van boeren. We hebben alleen boeren bevraagd en geen burgers, ketenpartijen, erfbetreders of andere partijen die invloed hebben. Dit zou interessant onderzoek kunnen opleveren. Het beeld van een 'goede boer' in de maatschappij wijkt waarschijnlijk af van het beeld van een 'goede boer' onder boeren. Om die reden voelen boeren zich vaak miskend en onbegrepen. Burgers hebben geen notie van hoe het boerenbedrijf in elkaar zit of van de economische consequenties van het integreren van natuur in het bedrijf. Wij hebben alleen gekeken naar boerensubculturen, en niet naar andere subculturen waar boeren lid van zijn (fanfare, kerk, etc.).

Verder is dit onderzoek een momentopname. Wat we kunnen zeggen over verandering van culturele normen is puur gebaseerd op de opmerkingen die door boeren zelf zijn gemaakt.

In dit rapport komt het agrarisch natuur- en landschapsbeheer veel aan bod. Wij hebben immers respondenten geworven onder deelnemers aan ANLb. ANLb vormt niveau 1 van natuurinclusieve landbouw, maar natuurinclusieve landbouw is breder. De casestudy beschrijvingen (3.x.5) maken duidelijk dat de respondenten een breed beeld hebben van natuurinclusieve landbouw, maar dat het agrarisch natuurbeheer hun voornaamste referentiekader is. Dit komt volgens ons omdat ANLb een goed ingeburgerde praktijk is, boeren er zich daardoor veel bij kunnen voorstellen en omdat het ANLb ook een belangrijk vehikel is voor boeren om niveau 2 en 3 in de praktijk te kunnen brengen. Natuurlijke plaagbestrijding en bestuiving worden bijvoorbeeld een plek geboden in akkerranden, die vanuit het ANLb kunnen worden gefinancierd. Biologische boeren doen vaak ook aan ANLb, en in de Noordelijke Friese Wouden is kringlooplandbouw door de agrarische natuurverenigingen ontwikkeld. Voor integrale natuurinclusieve bedrijfssystemen bestaan met uitzondering van Boeren voor Natuur nog geen subsidieregelingen, dus boeren van niveau 3 maken gebruik van ANLb en SNL (Subsidie Natuur en Landschap) om hun verdienmodel rond te krijgen. Biologische boeren associëren natuurinclusief vaak met biologisch, maar we hadden slechts enkele biologische boeren onder de respondenten. Alle Friese respondenten waren ook kringloopboer. Onze groep respondenten was in onze ogen geschikt voor de doelstellingen van het onderzoek. Als er al bovenmatige aandacht voor agrarisch natuurbeheer zou zijn, doet dit niet af aan onze bevindingen ten aanzien van de rol van cultureel kapitaal en de noodzaak van de ontwikkeling van natuurinclusieve subculturen. 


\subsection{Toevoegingen aan theorie en literatuur}

Ons onderzoek voegt ten eerste een breder beeld van 'goede boer' en 'goed landschap' toe aan de literatuur. In de literatuur is bekend dat volgens boeren een goede boer goed zorgt voor haar land, vee en bodem. Soms wordt daaraan toegevoegd dat een goede boer een goede ondernemer moet zijn, of dat hij geen vervuiler is. De respondenten in ons onderzoek vinden dat een goede boer ook rekening moet houden met maatschappij, milieu en biodiversiteit, sociaal moet zijn naar andere boeren toe, balans weet te houden tussen werk en privé, en een gelukkig mens is. Als het gaat om 'goed land', dan gaat het volgens de literatuur om netjes, strak en schoon, in andere woorden: productief. Onze respondenten vinden dat het van het doel afhangt, hoe goed land eruit moet zien. Als het doel is voedselproductie, dan is goed land inderdaad strak, schoon en netjes. Als het doel ook is biodiversiteit, dan mag het er best rommelig uitzien met ongelijkmatig gewas en onkruiden.

Ten tweede voegen wij een nuancering toe ten aanzien van het rondjes rijden en de rol van lokale sociale controle. Hoewel de boeren in onze casestudy's net als in eerder beschreven casestudy's rondjes rijden om elkaars land te beoordelen, zeggen ze er in hun bedrijfsvoeringskeuzes nauwelijks rekening mee te houden dat collega's een mening kunnen hebben over hun land. Zelfidentiteit, geworteld in culturele normen, lijkt een belangrijker drijfveer voor beslissingen dan sociale controle. Mogelijk is dit een gevolg van afkalvend lokaal sociaal kapitaal in boerengemeenschappen en de vorming van een diversiteit aan boerensubculturen die niet langer lokaal zijn. De mening van andere boeren kan er dan nog steeds toe doen, maar dan binnen een bepaalde subcultuur waarmee de boer zich identificeert.

Een derde toevoeging betreft de combinatie van culturele normen van 'goede boer' en 'goed landschap' met het concept van subculturen en het idee van langzame cultuurverandering als gevolg van de verandering van praktijken (op basis van structuration theory). We herkennen het bestaan van subculturen in de praktijk, maar ze zijn niet scherp af te bakenen en ze zijn ook niet statisch. Boeren maken deel uit van meer dan een subcultuur.

Een vierde toevoeging betreft de rol van het collectief agrarisch natuurbeheer in het introduceren, zichtbaar maken en herkenbaar maken van natuurinclusieve praktijken, en daarmee in de verandering van culturele normen in de landbouw.

\subsection{Van scheiden naar verweven en integreren}

In dit onderzoek is gewerkt met de definitie van natuurinclusieve landbouw in de Kamerbrief (zie paragraaf 1.1). Wij reflecteren niet op de betekenis van natuur of van natuurinclusief. In de interpretatie van de data uit de interviews en focusgroepen zijn we pragmatisch omgegaan met termen zoals biodiversiteit en natuur. We zijn er niet van uit gegaan dat natuur alleen maar in aangewezen natuurgebieden is te vinden en interpreteren natuur ook niet als de afwezigheid van cultuur.

Natuurinclusieve landbouw gaat voorbij het scheidingsconcept, waarbij landbouwgebieden toegewezen zijn aan landbouw en natuurgebieden aan natuur (Van Doorn et al., 2016). Natuurinclusieve landbouw gaat om verweving en om integratie: natuurelementen op het landbouwbedrijf, biodiversiteit op productiepercelen, gradiënten van meer en minder productief, en wederkerige relaties: natuur profiteert van landbouwkundig beheer en landbouw profiteert van ecosysteemdiensten. In het geval van integratie zijn landbouw en natuur nog nauwelijks van elkaar te onderscheiden. Dit is het geval in niveau 3 van natuurinclusieve landbouw volgens de Kamerbrief.

Het gaat er dus niet om dat productie geheel uit de culturele normen van de 'goede boer' en het 'goede landschap' zou moeten verdwijnen. 'Boeren zijn geen boswachters' en het is niet juist om van hen te verwachten dat zij hun identiteit zo vergaand aanpassen. We hebben hen immers nodig om te kunnen eten. Veeleer is er behoefte aan een discours dat voedselproductie en milieubehoud (inclusief biodiversiteit) integreert. Natuurinclusieve land- 
bouw is een voorbeeld van zo'n concept. De productie van voedsel maakt daar nog steeds nadrukkelijk onderdeel van uit. Zoals een van de respondenten het verwoordde: "als er geen opbrengst vanaf komt, is het geen natuurinclusieve landbouw meer". 


\section{Literatuur}

- Ahnström, J., Bengtsson, J., Berg, A., Hallgren, L., Boonstra, W.J., Björklund, J., 2013. Farmers' interest in nature and its relation to biodiversity in arable fields. International Journal of Ecology.

- Bouma, J., Koetse, M., 2020. Natuurinclusieve landbouw: Wat doen boeren, en wat willen boeren doen? Verkenning beleidsopties voor natuur-inclusieve landbouw. Planbureau voor de Leefomgeving, Den Haag.

- Bouma, J., Koetse, M., Polman, N., 2019. Financieringsbehoefte Natuurinclusieve Landbouw. Planbureau voor de Leefomgeving, Den Haag.

- Bourdieu, P., 1984. Distinction: A social critique of the judgement of taste. Routledge, London.

- Bourdieu, P., 1986. The forms of capital, in: Richardson, J.E. (Ed.), Handbook of theory of research for the sociology of education. Greenwood Press, pp. 46-58.

- Brodt, S., Klonsky, K., Tourte, L., 2006. Farmer goals and management styles: Implications for advancing biologically based agriculture. Agricultural Systems 89, 90-105.

- Burton, R.J.F., 2004. Seeing through the 'good farmer's' eyes: Towards developing an understanding of the social symbolic value of 'productivist' behaviour. Sociologia Ruralis 44, 195-215.

- Burton, R.J.F., 2014. The influence of farmer demographic characteristics on environmental behaviour: A review. Journal of Environmental Management 135, 19-26.

- Burton, R.J.F., Kuczera, C., Schwarz, G., 2008. Exploring farmers' cultural resistance to voluntary agrienvironmental schemes. Sociologia Ruralis 48, 16-37.

- Burton, R.J.F., Paragahawewa, U.H., 2011. Creating culturally sustainable agri-environmental schemes. Journal of Rural Studies 27, 95-104.

- Burton, R.J.F., Schwarz, G., 2013. Result-oriented agri-environmental schemes in Europe and their potential for promoting behavioural change. Land Use Policy 30, 628-641.

- Burton, R.J.F., Wilson, G.A., 2006. Injecting social psychology theory into conceptualisations of agricultural agency: Towards a post-productivist farmer self-identity? Journal of Rural Studies 22, 95-115.

- CBS, 2015. Statline databank. https://opendata.cbs.nl/statline\#/CBS/nl/ CBS, Heerlen

- De Krom, M.P.M.M., 2017. Farmer participation in agri-environmental schemes: Regionalisation and the role of bridging social capital. Land Use Policy 60, 352-361.

- Dessart, F.J., Barreiro-Hurlé, J., van Bavel, R., 2019. Behavioural factors affecting the adoption of sustainable farming practices: a policy-oriented review. European Review of Agricultural Economics 46, 417-471.

- Erisman, J.W., Eekeren, N.v., Doorn, A.v., Geertsema, W., Polman, N., 2017. Maatregelen Natuurinclusieve landbouw. Driebergen, ne: Louis Bolk Instituut.

- Falconer, K., 2000. Farm-level constraints on agri-environmental scheme participation: a transactional perspective. Journal of Rural Studies 16, 379-394.

- Farmar-Bowers, Q., Lane, R., 2009. Understanding farmers' strategic decision-making processes and the implications for biodiversity conservation policy. Journal of Environmental Management 90, 1135-1144.

- Fleury, P., Seres, C., Dobremez, L., Nettier, B., Pauthenet, Y., 2015. "Flowering Meadows", a result-oriented agri-environmental measure: Technical and value changes in favour of biodiversity. Land Use Policy 46, 103-114.

- Giddens, A., 1984. The constitution of society. University of California Press, Berkeley and Los Angeles.

- Ingram, J., Gaskell, P., Mills, J., Short, C., 2013. Incorporating agri-environment schemes into farm development pathways: A temporal analysis of farmer motivations. Land Use Policy 31, 267-279.

- Jongeneel, R.A., Polman, N.B.P., Slangen, L.H.G., 2008. Why are Dutch farmers going multifunctional? Land Use Policy 25, 81-94.

- Keenleyside, C., Radley, G., Tucker, G., Underwood, E., Hart, K., Allen, B., Menadue, H., 2014. Results-based payments for biodiversity guidance handbook: designing and implementing results-based agri-environment schemes 2014-20. Prepared for the European Commission, DG Environment, London: Institute for European Environmental Policy. 
- De Krom, M.P.M.M, Prins, A.G., 2019. Verduurzaming van landbouw via de keten: de kracht en beperkingen van private sturing in de aardappel- en de zuivelketen: beleidsstudie. Planbureau voor de Leefomgeving, Den Haag.

- Kuhfuss, L., Préget, R., Thoyer, S., Hanley, N., 2016. Nudging farmers to enrol land into agri-environmental schemes: The role of a collective bonus. European Review of Agricultural Economics 43, 609-636.

- Lokhorst, A.M., Staats, H., Van Dijk, J., Van Dijk, E., De Snoo, G., 2011. What's in it for Me? motivational differences between farmers' subsidised and non-subsidised conservation practices. Applied Psychology 60, 337-353.

- McGuire, J., Morton, L.W., Cast, A.D., 2013. Reconstructing the good farmer identity: Shifts in farmer identities and farm management practices to improve water quality. Agriculture and Human Values 30, 57-69.

- Methorst, R., 2016. Farmers' perception of opportunities for farm development. Wageningen, ne: Wageningen University.

- Mills, J., Gaskell, P., Ingram, J., Dwyer, J., Reed, M., Short, C., 2016. Engaging farmers in environmental management through a better understanding of behaviour. Agriculture and Human Values, 1-17.

- Polman, N.B.P., Slangen, L.H.G., 2008. Institutional design of agri-environmental contracts in the European Union: The role of trust and social capital. NJAS - Wageningen Journal of Life Sciences 55, 413-430.

- Pretty, J., 2003. Social Capital and the Collective Management of Resources. Science 302, 1912-1914.

- Primdahl, J., 1999. Agricultural landscapes as places of production and for living in owner's versus producer's decision making and the implications for planning. Landscape and Urban Planning 46, 143-150.

- Primdahl, J., Kristensen, L.S., 2011. The farmer as a landscape manager: Management roles and change patterns in a Danish region. 111, 107-116.

- Prokopy, L.S., Floress, K., Klotthor-Weinkauf, D., Baumgart-Getz, A., 2008. Determinants of agricultural best management practice adoption: Evidence from the literature. Journal of Soil and Water Conservation 63, 300-311.

- Raatikainen, K.J., Barron, E.S., 2017. Current agri-environmental policies dismiss varied perceptions and discourses on management of traditional rural biotopes. Land Use Policy 69, 564-576.

- Runhaar, H., Polman, N., 2018. Partnering for nature conservation: NGO-farmer collaboration for meadow bird protection in the Netherlands. Land Use Policy 73, 11-19.

- Runhaar, H.A.C., Melman, T.C.P., Boonstra, F.G., Erisman, J.W., Horlings, L.G., de Snoo, G.R., Termeer, C.J.A.M., Wassen, M.J., Westerink, J., Arts, B.J.M., 2017. Promoting nature conservation by Dutch farmers: a governance perspective. International Journal of Agricultural Sustainability 15, 264-281.

- Sanders, M., Westerink, J., Migchels, G., Korevaar, H., Geerts, R., Bloem, J., Alebeek, F.v., Schotman, A., Melman, D., Plomp, M., Muskens, G., Och, R.v., 2015. Op weg naar een natuurinclusieve duurzame landbouw. Wageningen, NL: Alterra Wageningen UR.

- Saunders, F.P., 2016. Complex Shades of Green: Gradually Changing Notions of the 'Good Farmer' in a Swedish Context. Sociologia Ruralis 56, 391-407.

- Schmitzberger, I., Wrbka, T., Steurer, B., Aschenbrenner, G., Peterseil, J., Zechmeister, H.G., 2005. How farming styles influence biodiversity maintenance in Austrian agricultural landscapes. Agriculture, Ecosystems and Environment 108, 274-290.

- Schoonhoven, Y., Runhaar, H., 2018. Conditions for the adoption of agro-ecological farming practices: a holistic framework illustrated with the case of almond farming in Andalusia. International Journal of Agricultural Sustainability 16, 442-454.

- Schroeder, L.A., Chaplin, S., Isselstein, J., 2015. What influences farmers 'acceptance of agrienvironment schemes? An ex-post application of the Theory of Planned Behaviour'. Landbauforschung Volkenrode 65, 15-28.

- Siebert, R., Toogood, M., Knierim, A., 2006. Factors affecting european farmers' participation in biodiversity policies. Sociologia Ruralis 46, 318-340.

- Sutherland, L.A., 2010. Environmental grants and regulations in strategic farm business decision-making: A case study of attitudinal behaviour in Scotland. Land Use Policy 27, 415-423. 
- Sutherland, L.A., 2013. Can organic farmers be 'good farmers'? Adding the 'taste of necessity' to the conventionalization debate. Agriculture and Human Values 30, 429-441.

- Sutherland, L.A., Burton, R.J., 2011. Good farmers, good neighbours? The role of cultural capital in social capital development in a Scottish farming community. Sociologia Ruralis 51, 238-255.

- Van der Ploeg, J.D., Laurent, C., Blondeau, F., Bonnafous, P., 2009. Farm diversity, classification schemes and multifunctionality. Journal of Environmental Management 90, S124-S131.

- Van der Ploeg, J.D., Ventura, F., 2014. Heterogeneity reconsidered. Current Opinion in Environmental Sustainability 8, 23-28.

- Van Doorn, A., Melman, D., Westerink, J., Polman, N., Vogelzang, T., Korevaar, H., 2016. Food-for-thought : natuurinclusieve landbouw. [Wageningen], ne: ,Wageningen University \& Research.

- Van Herzele, A., Gobin, A., Van Gossum, P., Acosta, L., Waas, T., Dendoncker, N., Henry de Frahan, B., 2013. Effort for money? Farmers' rationale for participation in agri-environment measures with different implementation complexity. Journal of Environmental Management 131, 110-120.

- Vanclay, F., Mesiti, L., Howden, P., 1998. Styles of farming and farming subcultures: Appropriate concepts for australian rural sociology? Rural Society 8, 85-107.

- Wauters, E., D'Haene, K., Lauwers, L., 2017. The social psychology of biodiversity conservation in agriculture. Journal of Environmental Planning and Management 60, 1464-1484.

- Westerink, J., Smit, A.B., Dijkshoorn-Dekker, M.W.C., Polman, N.B.P., Vogelzang, T.A., 2018. Boeren in Beweging. Hoe boeren afwegingen maken over natuurinclusieve landbouw en hoe anderen hen kunnen helpen. Wageningen Environmental Research, Wageningen.

- Wilson, G.A., 1997. Factors influencing farmer participation in the environmentally sensitive areas scheme. Journal of Environmental Management 50, 67-93.

- Wilson, G.A., Hart, K., 2000. Financial imperative or conservation concern? EU farmers' motivations for participation in voluntary agri-environmental schemes. Environment and Planning A 32, 2161-2185. 


\section{Verantwoording}

Dit project werd begeleid door Michiel de Krom van het Planbureau voor de Leefomgeving en Rosalie van Dam van Wageningen Environmental Research vanuit de Wettelijke Onderzoekstaken (WOT) Natuur en Milieu. In de beginfase van het project hebben Henk van Zeijts en Jetske Bouma van PBL bijgedragen aan de vraagstelling en afbakening van het onderzoek. Twee workshops bij PBL hebben grote invloed gehad op de vormgeving van het project. Hartelijk dank aan allen die daarin hebben deelgenomen. De begeleidingscommissie bestond uit Petra van Egmond (PBL), Martijn Vink (PBL), Joep Dirkx (WOT), Hens Runhaar (Wageningen Universiteit) en Mariska Harte (Ministerie van LNV).

De agrarische collectieven VALA, NFW, Poldernatuur en Natuurrijk Limburg zijn van grote hulp geweest bij het vinden van respondenten. Wij bedanken de collectieven en de 24 boeren die hebben meegedaan in het onderzoek. Alle respondenten hebben hun persoonlijke gespreksverslag en het verslag van hun focusgroep ontvangen. Bij elk van deze collectieven zijn de resultaten van het onderzoek gepresenteerd en besproken (Poldernatuur 18 december 2019, Natuurrijk Limburg 14 januari 2020, NFW in voorbereiding, VALA in voorbereiding).

Verder is dit onderzoek gepresenteerd tijdens een seminar aan de universiteit van Newcastle (UK) op 23 oktober 2019, tijdens een symposium over governance of behaviour in Wageningen op 7 november 2019, tijdens de Dag van het Gedrag in Den Haag op 29 november 2019 en bij het Planbureau voor de Leefomgeving op 17 februari 2020.

Wij bedanken oud-collega Eva van den Broek voor haar bijdrage aan het onderzoek. De transcripties van de geluidsopnamen zijn gemaakt door Anouk Boudewijn en Pauline Brorens.

De review van dit rapport is uitgevoerd door de begeleidingscommissie.

De auteurs bedanken allen voor hun bijdrage aan het tot stand komen van deze rapportage. 


\section{Bijlage 1 \\ Factoren die een rol spelen bij keuzes van boeren ten aanzien van natuur}

\section{Inleiding}

Deze bijlage geeft vanuit de literatuur een overzicht van factoren die een rol spelen bij de keuzes van boeren met betrekking tot natuur op hun bedrijf. Deze factoren omvatten ook de culturele normen waar dit onderzoek zich op heeft toegespitst. Deze bijlage geeft echter een breder overzicht.

Natuurinclusieve landbouw is een relatief nieuwe en strikt Nederlandse term, die diverse bestaande praktijken van (agrarisch) natuurbeheer, stimuleren van functionele agrobiodiversiteit en het beperken van negatieve impact op natuur omvat. We hebben daarom in algemene zin in de literatuur gekeken naar factoren die keuzes beïnvloeden ten aanzien van natuur op het bedrijf. Veel literatuur houdt verband met deelname aan landbouwmilieumaatregelen (agri-environment schemes). Ook zijn er wat studies naar motivatie voor biologische landbouw. Ons is geen gedragsliteratuur bekend ten aanzien van agro-ecologische landbouw.

Deze notitie is niet gebaseerd op een volledige review van de literatuur op dit onderwerp. Dat zou al een groot onderzoeksproject op zich zijn. Bestaande literatuuroverzichten zijn bijvoorbeeld te vinden in Dessart et al. (2019), Siebert et al. (2006), Mills et al. (2016), Schoonhoven and Runhaar (2018) en Prokopy et al. (2008). Ons literatuuronderzoek was vooral gericht op het in beeld krijgen van het brede scala aan factoren die de keuzes van boeren beïnvloeden.

Deze bijlage is als volgt opgebouwd. Eerst gaan we hoog over: verschillende typen factoren, samenspel van diverse factoren, verschillende typen boeren (die daarmee samenhangend andere keuzes maken), en verschillende ambitieniveaus ten aanzien van natuurinclusieve landbouw. Vervolgens gaan we in op specifieke factoren, inclusief mogelijke barrières.

\section{Hoog over}

Volgens Runhaar et al. (2017) zijn er vier condities waaraan moet worden voldaan voordat boeren natuurinclusief gaan werken. Ze moeten 'willen', 'kunnen', 'moeten' en 'mogen'. Wij gebruiken dit raamwerk om de literatuur over factoren die een rol spelen bij (al dan niet natuurinclusieve) keuzes van boeren samen te vatten. Binnen de vier kwadranten zijn diverse factoren onder te brengen. Daarnaast beïnvloeden de kwadranten elkaar. Specifieke invloeden zijn in figuur 4 met pijlen aangegeven. De factoren zijn in de paragraaf 'Specifieke factoren' uitgewerkt.

De motivatie van de ondernemer ofwel het "willen" is de eerste en belangrijkste randvoorwaarde. Natuurinclusieve landbouw moet echter ook "kunnen": het moet inpasbaar zijn in de bedrijfsvoering en de boer moet de beschikking hebben over de benodigde middelen, kennis en vaardigheden. "Willen" en "kunnen" zijn kenmerken van de boer zelf. Het gaat echter niet zonder de omgeving van de boer ofwel zijn of haar gezin, familie, vrienden, buren, directe collega's (relationele netwerk), maar ook van erfbetreders (ketenpartijen/markt, de dierenarts, accountant, etc.), overheden, agrarische collectieven, natuurbeschermingsorganisaties en kennisinstellingen (bedrijfs- 
netwerk). Vanuit die omgeving kan een beroep worden gedaan op de ondernemer om naar een andere bedrijfsvoering over te gaan ("moeten"). Dat kan in de vorm van een marktvraag, regelgeving, subsidieregelingen, publieke opinie of een rechtstreekse vraag om iets te doen vanuit bijvoorbeeld buren of collega's. De omgeving kan echter ook zorgen voor een gebrek aan ruimte om in de richting van natuurinclusieve landbouw te bewegen ("mogen"). Die beperkingen kunnen het gevolg zijn van regels vanuit overheid, keten of bank die bepaalde natuurinclusieve maatregelen en innovaties in de weg staan of van culturele normen binnen de boerengemeenschap die boeren ontmoedigen om het hoofd boven het maaiveld uit te steken als het gaat om natuur. Het "moeten" en het "mogen" hebben invloed op het "willen" en het "kunnen".

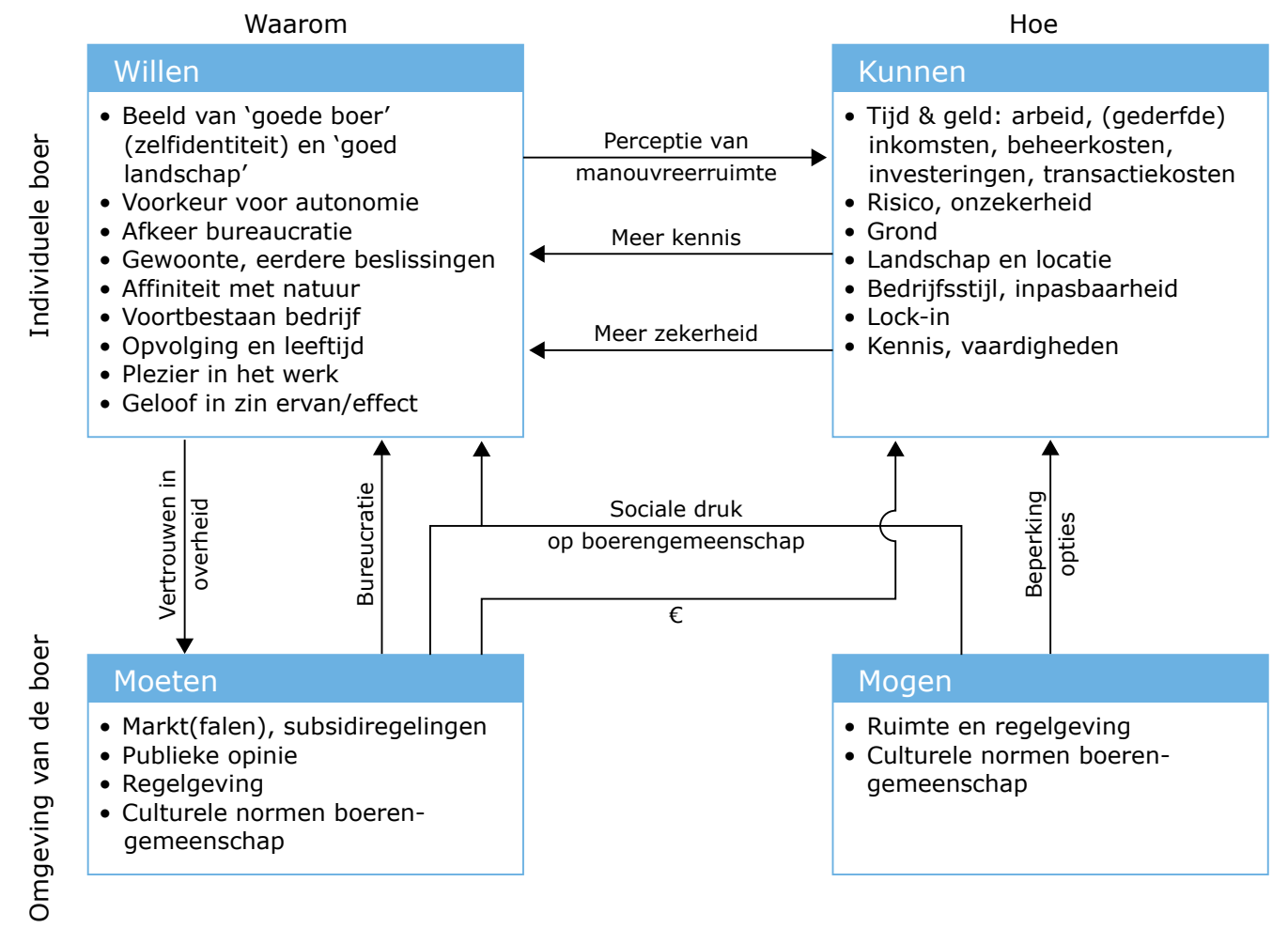

Figuur 4 Willen, kunnen, moeten en mogen als categorieën factoren die keuzes van boeren ten aanzien van natuur beïnvloeden.

Runhaar is niet de enige die benadrukt dat de totstandkoming van keuzes van boeren het gevolg is van een complex samenspel van meerdere factoren: dit punt wordt ook gemaakt door o.a. Van Herzele et al. (2013), FarmarBowers and Lane (2009), Mills et al. (2016) en Westerink et al. (2018).

Bedrijfseconomische factoren alleen zijn onvoldoende om het gedrag van boeren te begrijpen. Sterker nog, het alleen inzetten op financiële prikkels leidt tot beleid dat niet leidt tot blijvende verandering, als het niet bijdraagt aan een cultuurverandering en intrinsieke motivatie voor natuur (Lokhorst et al., 2011; Mills et al., 2016). Tegelijkertijd vertellen sociale en psychologische factoren ook niet het hele verhaal: er zijn boeren die wel willen, maar niet kunnen. Mills et al. (2016) spreken bij hen van een 'value - action gap'. Het is dus ook niet reëel om alleen op motivatie in te zetten: voor een verandering van bedrijfsvoering, zeker als het gaat om een fundamenteel andere koers van het bedrijf, zijn ook middelen nodig, waaronder financiële (Siebert et al., 2006; Wauters et al., 2017; Westerink et al., 2018). Farmar-Bowers and Lane (2009) hypothetiseren dat actie voortkomt uit motivatie plus een strategische mogelijkheid. Die mogelijkheid bestaat uit kenmerken van de boer en de boerderij en uit externe kansen. 'Kunnen' is overigens voor een groot deel subjectief: risicobeleving en de perceptie van manoeuvreerruimte zijn mede bepalend in de mogelijkheden en kansen die boeren zien (Farmar-Bowers and Lane, 2009; Jongeneel et al., 2008; Methorst, 2016). 
Daarnaast is het onverstandig om alle boeren over een kam te scheren. Diverse auteurs benadrukken dat rekening moet worden gehouden met een diversiteit aan 'bedrijfsstijlen', die staan voor een complex geheel van percepties, praktijk, historie en bedrijfsstrategie waarbinnen een boer zijn keuzes maakt (Brodt et al., 2006; Ingram et al., 2013; Methorst, 2016; Van der Ploeg et al., 2009). Brodt et al. (2006) onderscheiden bijvoorbeeld de 'milieurentmeesters', de 'rekenende producenten' en de 'netwerkende ondernemers'. Verschillende typen boeren maken andere keuzes en reageren anders op beleidsinterventies. Zij hebben andere benaderingen nodig om hen te stimuleren het gewenste gedrag te vertonen. Deze bedrijfsstijlen zijn redelijk stabiel, maar zeker niet onveranderlijk. De levenscyclus van het bedrijf in relatie tot de levensfases van de boer heeft daar invloed op (FarmarBowers and Lane, 2009). Opvolging is een belangrijk moment voor aanpassing van de bedrijfsstijl (Ingram et al., 2013). De bedrijfsstijl bakent behoorlijk af wat voor een boer mogelijk is (0). In paragraaf 2.3 gaan we dieper op in op bedrijfsstijlen in relatie tot culturele normen.

Het ambitieniveau van NIL met betrekking tot natuur zal grote invloed hebben op de mogelijkheden en onmogelijkheden die boeren zien (Van Herzele et al., 2013). Bij een laagdrempelige insteek zullen meer boeren het haalbaar achten om met NIL aan de slag te gaan. Bij een ambitieuze invulling, die vergaande aanpassing vraagt van het bedrijf, zullen meer boeren barrières ervaren. Uit diverse studies blijkt dat boeren verschillende maatregelen verschillend beoordelen (Polman and Slangen, 2008; Wauters et al., 2017).

\section{Kader 4}

In hoofdstuk 2 is een aantal concepten gecombineerd die met culturele normen te maken hebben. Hierin zijn aspecten aan bod gekomen van willen, kunnen, moeten en mogen. Het gaat om:

- Zelfidentiteit (willen)

- Bedrijfsstijlen (willen en kunnen)

- Culturele normen (moeten en mogen)

- Leren in relatie tot cultureel en sociaal kapitaal (kunnen)

Voor het totaalbeeld komen deze aspecten in de paragrafen hieronder nog kort aan bod.

\section{Specifieke factoren}

\section{Structurele factoren}

Met structurele factoren wordt in de literatuur over keuzes van boeren vaak gedoeld op factoren zoals bedrijfsomvang, sector, leeftijd, opleidingsniveau en gender. Het voordeel van een focus op dergelijke factoren is dat dit het mogelijk maakt om beleidsinterventies op identificeerbare groepen te richten. Deze factoren hebben echter als nadeel dat ze geen inzicht geven in hoe de keuzes tot stand komen. De relaties tussen deze factoren en de keuzes zijn verre van eenduidig, met name omdat de structurele factoren proxy's zijn voor de factoren die er echt toe doen, en dat die mechanismen niet lineair zijn. 


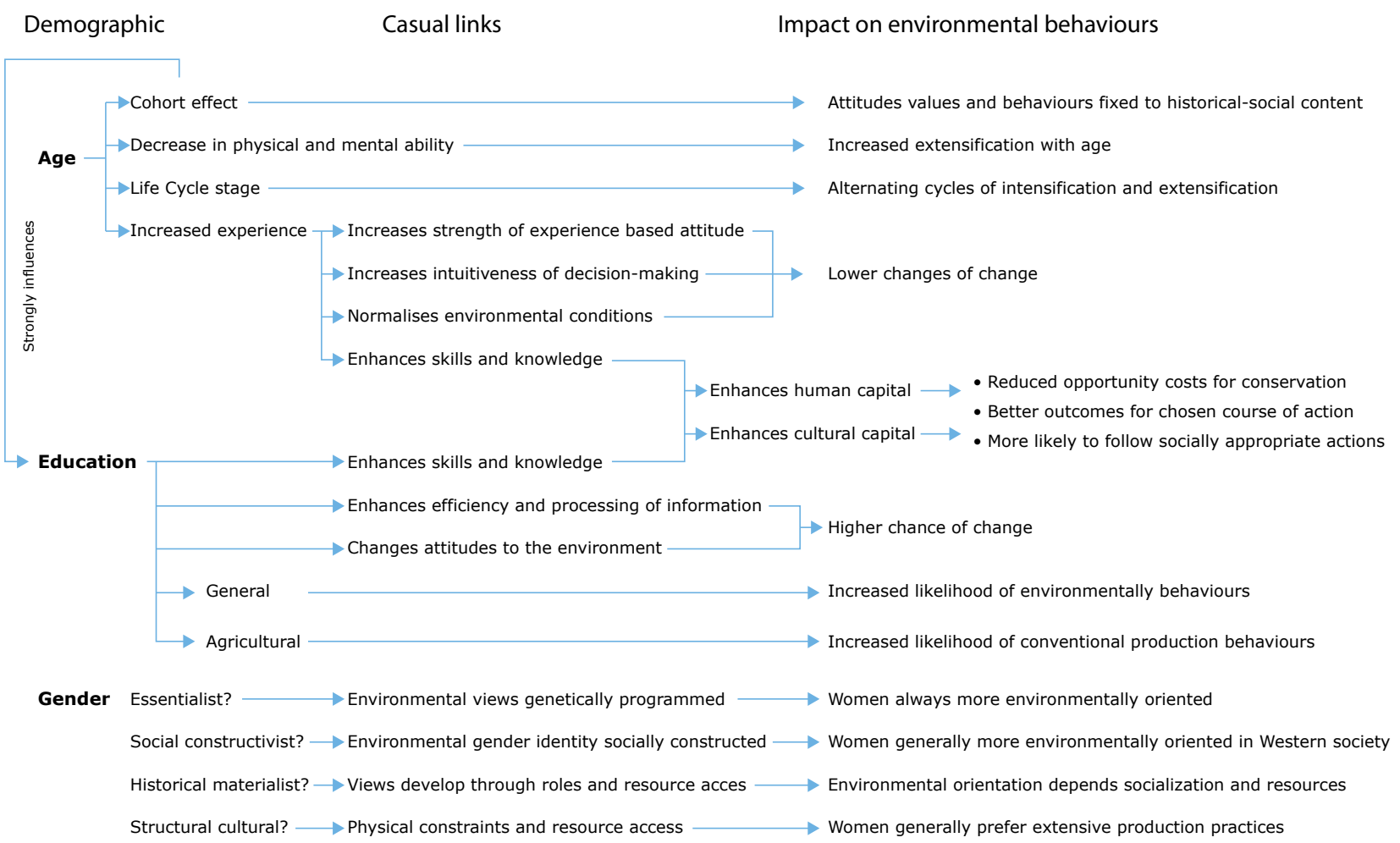

Figuur 5 De relaties tussen leeftijd, ervaring, opleiding en gender van boeren en milieubewust gedrag.

Een goed overzichtsartikel is dat van (Burton, 2014). Hij geeft aandacht aan leeftijd, ervaring, opleiding en gender (zie figuur 5). Hij laat zien dat deze factoren niet los van elkaar staan, en bovendien via andere factoren invloed hebben op gedrag. Als gevolg daarvan kunnen geen eenduidige relaties worden gelegd tussen bijvoorbeeld leeftijd en gedrag. Het is niet zo dat oudere boeren altijd minder milieubewust zijn dan jongere: dat dit uit sommige studies komt, heeft volgens Burton meer te maken met het leeftijdscohort dat in een bepaalde tijd is opgegroeid, de productivistische visie die in die tijd opgeld deed en de inhoud van de lesstof in die tijd. Omgekeerd kan deelname van oudere boeren aan agrarisch natuurbeheer te maken hebben met het ontbreken van een opvolger en de wens om het bedrijf rustig uit te faseren. Ook het wel of niet hebben van een opvolger helpt echter niet per se om keuzes van boeren te begrijpen. Hoe dat uitpakt hangt sterk af van de wensen van de opvolger, dan wel van de uitfaserende boer. Sommige boeren benoemen dat ze op latere leeftijd milder worden en meer oog krijgen voor duurzaamheid (Mills et al., 2016; Westerink et al., 2018). Jongeneel et al. (2008) vonden voor Nederlandse boeren geen significant verband tussen leeftijd en deelname aan agrarisch natuurbeheer. Met betrekking tot opleiding concludeert Burton dat de inhoud van de lesstof een grotere invloed heeft op natuurvriendelijk gedrag dan opleidingsniveau.

Structurele factoren die te maken hebben met 'kunnen', zoals grondpositie en bedrijfstype, worden behandeld in de subparagraaf 'Kunnen'. 


\section{Willen}

Beeld van 'goede boer' en 'goed landschap' 5

Zelfidentiteit heeft een sterke relatie met (de intentie tot) natuurvriendelijk gedrag (Jongeneel et al., 2008; Lokhorst et al., 2011; Wauters et al., 2017). Dit gaat over hoe een boer zichzelf ziet, of hij zichzelf ziet als 'iemand die dit soort dingen doet', en of hij maatregelen voor natuur ziet als passend bij hem-/haarzelf en bij het bedrijf. Burton (2004) laat zien dat de praktijk van het verhogen van de productie onderdeel is geworden van de identiteit van een 'goede boer'. Dit heeft te maken met de trots die boeren baseren op het leveren van voedsel en het 'voeden van de wereld' (Mills et al., 2016). Boeren hebben er moeite mee om hoog productief land 'op te offeren' voor natuur (Wauters et al., 2017). Een productief landschap is een zichtbaar teken van vakmanschap. Een terugkerend bezwaar van boeren bij natuurmaatregelen is de angst voor meer onkruid: niet alleen vanwege een mogelijk lagere productie, maar ook omdat het hun trots als boer aantast (Burton, 2004; Schroeder et al., 2015; Westerink et al., 2018). Er is echter ook onderzoek dat de indruk geeft dat deze discoursen aan het verschuiven zijn, en zorg voor de natuur ook door boeren als goede landbouwpraktijk kan worden beschouwd (Mills et al., 2016; Sutherland, 2010; Wilson and Hart, 2000). Ook is er onderzoek dat laat zien dat boeren gehecht zijn aan hun landschap als cultureel erfgoed en er deels hun identiteit aan ontlenen (Raatikainen and Barron, 2017). In het onderzoek van Westerink et al. (2018) gebruikten sommige boeren termen als 'natuurinclusief' en 'weidevogelboer' om zichzelf te omschrijven. Zelfidentiteit en culturele normen (zie onder 'moeten' en 'mogen') waren belangrijke aanknopingspunten voor het empirisch onderzoek in deze studie (zie de hoofdstukken 3-5).

\section{Voorkeur voor autonomie}

Boeren koesteren de vrijheid en autonomie van het boer-zijn (Jongeneel et al., 2008; Westerink et al., 2018). Ze zijn graag eigen baas. Waar ze vrijwillig iets voor de natuur zouden doen, kan die motivatie verdwijnen als hen beperkingen worden opgelegd (Lokhorst et al., 2011; Siebert et al., 2006).

\section{Afkeer van bureaucratie}

Samenhangend met de voorkeur voor autonomie, hebben veel boeren een hekel aan papierwerk (Westerink et al., 2018). De bureaucreatie is een drempel om mee te doen met regelingen voor agrarisch natuurbeheer (Schroeder et al., 2015).

\section{Gewoonte, eerdere beslissingen}

Mensen doen veel dingen uit gewoonte, omdat ze dat nu eenmaal zo gewend zijn, of omdat dat in lijn is met eerdere beslissingen (Farmar-Bowers and Lane, 2009; Pretty, 2003). Dit verklaart waarom gedragsverandering zo moeilijk kan zijn. Tegelijkertijd kan het opdoen van ervaringen met agrarisch natuurbeheer de affiniteit met natuur vergroten (Wilson and Hart, 2000).

\section{Affiniteit met natuur}

In de studie van Wilson and Hart (2000) kwam de wens om bij te dragen aan natuurbehoud als een van de voornaamste redenen naar voren om mee te doen met een regeling voor agrarisch natuurbeheer (zie ook Siebert et al. $(2006)^{6}$ ). Ook het onderzoek van Mills et al. (2016) en Westerink et al. (2018) wijst op een groot belang van persoonlijke interesse in natuur. Interesse in natuur wordt vaak op jonge leeftijd gewekt (Farmar-Bowers and Lane, 2009).

\section{Plezier in het werk}

Boeren kunnen ervan genieten om wilde dieren te zien op hun land en dit draagt bij aan hun werkplezier en gevoel van eigenwaarde (Mills et al., 2016; Westerink et al., 2018). Het boeren is een manier van leven, een levensstijl waar een boer van kan genieten (Farmar-Bowers and Lane, 2009; Westerink et al., 2018). Het kan voor boeren een sport zijn om meer nesten te hebben dan de buren (Westerink et al., 2018).

5 Zie onder 'mogen' voor de culturele component van het beeld van 'goede boer' en 'goed landschap'.

6 Dit artikel betreft een literatuuroverzicht: bij verwijzingen naar dit artikel zijn er vaak onderliggende referenties 


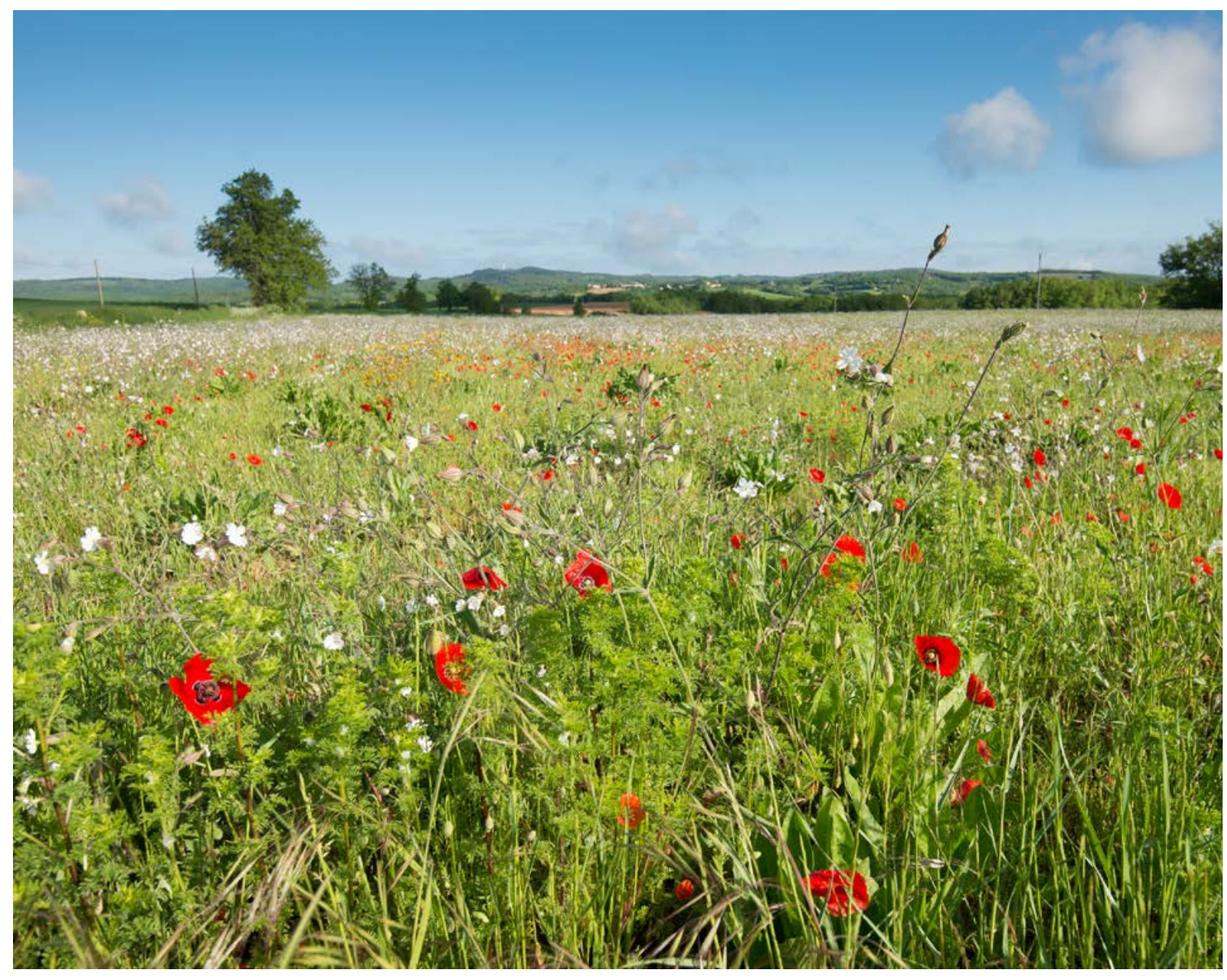

Geloof in zin ervan/ effect

Positieve uitkomsten, of een positieve verwachting van de effectiviteit werken motiverend (Schroeder et al., 2015). Dit kan gaan om bijvoorbeeld meer biodiversiteit, mooi landschap, minder uitspoeling en/ of een beter imago van de sector (Schroeder et al., 2015; Siebert et al., 2006; Van Herzele et al., 2013; Wauters et al., 2017). Goed bodembeheer is een belangrijke reden om mee te doen (Van Herzele et al., 2013). 'Geen voordeel zien' kan een belangrijke reden zijn om niet mee te doen (Wilson and Hart, 2000).

\section{Voortbestaan bedrijf en opvolging}

Het voortbestaan van het bedrijf gaat verder dan economische motivatie (Ingram et al., 2013). Het gaat om het voortzetten van de familietraditie en het doorgeven van het bedrijf/ een manier van leven aan de volgende generatie (Siebert et al., 2006; Wilson and Hart, 2000). Dit raakt aan de diepste drijfveren van boeren (Farmar-Bowers and Lane, 2009). Hij of zij is vaak vooral aan het werk voor het gezin (Farmar-Bowers and Lane, 2009).

\section{Het gezin}

De naaste familie heeft grote invloed op de keuzes van de boer, meer dan bijvoorbeeld de adviseur (FarmarBowers and Lane, 2009; Schroeder et al., 2015). Dit geldt in het bijzonder voor de partner en de vorige generatie (Mills et al., 2016; Westerink et al., 2018).

\section{Kunnen}

\section{Perceptie van manoeuvreerruimte}

Kunnen gaat niet zozeer om een objectief gegeven, maar met name om de inschatting van de boer ten aanzien van de mogelijkheden. Dit kan gaan over de mogelijkheden zelf, en over de eigen mate van controle over het gedrag (Farmar-Bowers and Lane, 2009; Methorst, 2016; Wauters et al., 2017). 
Risico, onzekerheid

Boeren hebben te maken met onzekerheid in opbrengsten en in de markten voor voedsel en arbeid, waardoor ze zich niet graag voor lange termijn vastleggen in contracten voor agrarisch natuurbeheer (Sutherland, 2010). Risicominimalisering is een belangrijke overweging bij beslissingen over deelname aan agrarisch natuurbeheer (Siebert et al., 2006).

Tijd \& geld: arbeid, (gederfde) inkomsten, beheerkosten, investeringen, transactiekosten

Zorg om een toename van de werklast kan een barrière zijn (Van Herzele et al., 2013; Wauters et al., 2017), evenals zorg om een lagere productie (Wauters et al., 2017). Er bestaan verschillen tussen boeren in hoeverre ze een gebrek aan financiële compensatie als barrière ervaren om iets voor de natuur te doen (Lokhorst et al., 2011; Wauters et al., 2017). Subsidies voor agrarisch natuurbeheer zijn in heel Europa gebaseerd op het compenseren van gemaakte kosten en gederfde inkomsten (Kuhfuss et al., 2016).

Het streven naar een economisch gezond boerenbedrijf kan een reden zijn om mee te doen met subsidieregelingen: de stabiele inkomsten worden gewaardeerd (Siebert et al., 2006; Sutherland, 2010; Wilson and Hart, 2000). In de studie van Wilson and Hart (2000) met casestudy's in 7 landen kwamen economische overwegingen als belangrijkste reden uit de bus om mee te doen met de regelingen voor agrarisch natuurbeheer, dit komt overeen met de studie van Van Herzele et al. (2013). Een te lage vergoeding kan een reden zijn om niet mee te doen (Wilson and Hart, 2000). In het geval van bijvoorbeeld het terugdringen van emissies zijn de kosten individueel, en de baten vooral collectief. Dit risico van free-riding kan een drempel zijn om actie te ondernemen (Kuhfuss et al., 2016).

\section{Grond}

Te weinig grond en hoge grondkosten kunnen een barrière vormen voor extensivering of het aanleggen van akkerranden of plas-dras (Wauters et al., 2017; Westerink et al., 2018). Boeren met grond in eigendom kunnen meer vrijheid ervaren om mee te doen met agrarisch natuurbeheer dan pachtboeren (Wilson and Hart, 2000). Natuurbeheer kan leiden tot beperking van de landgebruiksrechten, dit kan een drempel zijn (Jongeneel et al., 2008). Als grond beschikbaar wordt gesteld, kan daar echter ook natuurgericht gedrag mee worden gestimuleerd (Westerink et al., 2018).

\section{Landschap en locatie}

Het landschap bepaalt de fysieke beperkingen van de mogelijkheden voor landbouw en de natuurmaatregelen (Siebert et al., 2006). Boeren met onproductieve landschapselementen en marginale stukken grond zijn vaak geneigd om dat aan de natuur te laten (Ingram et al., 2013). Het kan aantrekkelijk zijn om er het beste van te maken door op die stukken contracten af te sluiten voor agrarisch natuurbeheer (Van Herzele et al., 2013). Voor boeren kunnen de beperkingen van het landschap een kans betekenen om op een alternatieve manier te boeren en te leven (Ingram et al., 2013). Jongeneel et al. (2008) vonden een relatie tussen locatie en agrarisch natuurbeheer, dat met het landschap en met het overheidsbeleid te maken kan hebben. In Zweden werd een relatie gelegd tussen interesse van boeren in natuur en het landschap waarin zij gevestigd waren; bovendien bleek dat op land van in natuur geïnteresseerde boeren meer biodiversiteit voorkwam (Ahnström et al., 2013). Ook de melkveehouders in Westerink et al. (2018) leggen de relatie tussen het landschap, de cultuur in het gebied, de bereidheid om aan weidevogelbeheer te doen en het vóórkomen van vogels.

\section{Type bedrijf en inpasbaarheid}

Het type bedrijf maakt uit (bijvoorbeeld melkvee of vleesvee, parttime of fulltime, veehouderij of akkerbouw), maar hoe dit uitpakt voor natuur kan verschillen per regio (Jongeneel et al., 2008; Polman and Slangen, 2008; Wauters et al., 2017; Wilson and Hart, 2000). Polman and Slangen (2008) vonden geen effect van de omvang van het bedrijf. Volgens Sutherland (2010), Wilson and Hart (2000) en Primdahl and Kristensen (2011) zijn hobbyboeren echter minder afhankelijk van financiële compensatie en is de drempel om iets voor de natuur te doen daardoor lager. Dat wil nog niet zeggen dat ze de moeite willen doen om mee te doen met een subsidieregeling (Wilson and Hart, 2000). Falconer (2000) maakt zich zorgen over de transactiekosten die voor kleine bedrijven 
relatief groot zijn. (Jongeneel et al., 2008) vonden onder Nederlandse boeren dat natuurbeheer relatief vaak werd gecombineerd met een baan buiten het boerenbedrijf, in tegenstelling tot andere vormen van verbreding.

Het onderzoek van Westerink et al. (2018) laat zien dat bedrijfssystemen complex zijn en dat veel aspecten met elkaar samenhangen. Zo grijpt later maaien in op o.a. het rantsoen, de melkproductie, de kosten van extra voer, en uiteindelijk ook het veeras. Inpasbaarheid is een zeer belangrijke overweging voor boeren als ze kiezen om wel of niet mee te doen met een regeling voor agrarisch natuurbeheer (Siebert et al., 2006; Van Herzele et al., 2013; Wilson, 1997; Wilson and Hart, 2000). Dit geldt met name voor de zwaardere maatregelen, die eerder in conflict kunnen zijn met de bestaande bedrijfsstrategie. Volgens Wilson and Hart (2000) zijn extensieve bedrijven beter ingericht op agrarisch natuurbeheer, maar dit kwam niet uit de studie van Polman and Slangen (2008). Agrarisch natuurbeheer kan een manier zijn om niet-productieve delen van het bedrijf (zoals landschapselementen) toch in te passen (Van Herzele et al., 2013). Het willen integreren van natuur op het bedrijf kan de bedrijfsstijl zijn (Van Herzele et al., 2013). Boeren met zo'n bedrijfsstijl zijn bereid om relatief zware maatregelen uit te voeren.

Lock-in

Als gevolg van eerdere investeringen, in combinatie met de financieringslasten kan het omschakelen naar andere, natuurinclusieve bedrijfssystemen economisch niet haalbaar zijn (Jongeneel et al., 2008). Hierbij speelt ook een rol dat de subsidieregelingen meestal te weinig lange termijnperspectief bieden om grote nieuwe investeringen te doen. De angst om niet meer terug te kunnen is in het licht van de korte termijn van de subsidies een barrière om de meer ingrijpende groene diensten te leveren (Jongeneel et al., 2008; Westerink et al., 2018).

\section{Kennis, vaardigheden}

De kennis en vaardigheden van een boer zijn mede bepalend voor zijn of haar beoordeling van de passendheid en haalbaarheid van een ontwikkelingsrichting (Farmar-Bowers and Lane, 2009).

\section{Technologie}

Boeren zien kansen in het inzetten van technologie voor natuurbeheer op het bedrijf (Westerink et al., 2018).

\section{Moeten}

Markt(falen), subsidieregelingen

Marktvraag kan een beroep doen op boeren om ecosysteemdiensten te leveren, maar de markt faalt ten aanzien van natuur (Jongeneel et al., 2008). Om die reden zijn subsidieregelingen voor agrarisch natuurbeheer gangbaar in Europa en diverse andere landen. Runhaar et al. (2017) zien grote mogelijkheden voor natuur op boerenland als die marktvraag wel op gang zou komen, via eisen die door ketenpartijen aan boeren worden gesteld. Boeren hebben vaak een voorkeur voor een betaling voor agrarische natuur via de productprijzen boven een betaling via subsidie (Westerink et al., 2018).

\section{Publieke opinie}

Boeren die aangeven dat ze bereid zijn om maatregelen voor natuur te nemen, zijn gevoeliger voor sociale normen vanuit de maatschappij (Wauters et al., 2017). Boeren trekken zich de negatieve publiciteit over de landbouw aan, dit zet hen aan het denken over hun maatschappelijke verantwoordelijkheid (Mills et al., 2016; Westerink et al., 2018), of het drukt hen in de verdediging (Siebert et al., 2006).

\section{Regelgeving}

Regelgeving geeft aan wat de maatschappij van boeren verwacht en is daarmee een uitdrukking van een sociale norm (Runhaar et al., 2017; Wauters et al., 2017). Regelgeving kan ook een reden zijn voor boeren om mee te doen met een regeling voor agrarisch natuurbeheer die voortbouwt op die regels, om er dan nog maar wat geld voor te krijgen (Van Herzele et al., 2013). 


\section{Culturele normen boerengemeenschap}

Boerenorganisaties kunnen invloed hebben op intenties van boeren om natuurgerichte maatregelen te nemen (Wauters et al., 2017). Boeren doen sneller mee als ze zeker weten dat hun buren ook meedoen, of als hun buren goede ervaringen hebben met het afsluiten van contracten (Kuhfuss et al., 2016; Siebert et al., 2006). Wilson and Hart (2000) vonden echter geen grote invloed van 'praten met andere boeren' op deelname aan agrarisch natuurbeheer, hoewel boeren dat wel als belangrijkste bron van informatie beschouwen.

\section{Sociale inbedding algemeen}

Boeren die deel uitmaken van sociale netwerken (niet-landbouw) doen vaker mee aan agrarisch natuurbeheer (Polman and Slangen, 2008). Interactie met burgers kan boeren positiever laten denken over een meer biodivers landschap (De Krom, 2017). Voor boeren die natuur vergaand willen integreren op het bedrijf, is het respect binnen de lokale gemeenschap van belang, onder meer vanwege de mogelijkheid tot het verkopen van lokale producten (Van Herzele et al., 2013).

\section{Voorlichting}

Voorlichting door publieke organisaties heeft een positief effect op deelname, voorlichting door erfbetreders een negatieve (Polman and Slangen, 2008; Schroeder et al., 2015). Ook andere studies wijzen op het belang van een goede relatie met de lokale ambtenaar (Siebert et al., 2006).

\section{Vertrouwen in de overheid}

Boeren met een laag vertrouwen in de overheid doen niet graag mee met subsidieregelingen voor agrarisch natuurbeheer (Polman and Slangen, 2008). Stabiel beleid draagt bij aan dat vertrouwen (Polman and Slangen, 2008). Een top-down benadering kan averechts effect hebben (Siebert et al., 2006).

\section{Mogen}

Ruimte in regelgeving

Boeren voelen zich door de regels van de subsidieregelingen voor agrarisch natuurbeheer beperkt in hun vrijheid: ze worden minder flexibel in het beheer van hun bedrijf (Schroeder et al., 2015). Ze vrezen aanscherpingen van de regelgeving (Westerink et al., 2018). Gebrek aan flexibiliteit binnen de regeling kan een belangrijke reden zijn om niet mee te doen (Van Herzele et al., 2013; Wilson, 1997; Wilson and Hart, 2000). Ook tegenstrijdige regels, zoals het moeten beschermen van vogels èn predatoren, werken demotiverend (Westerink et al., 2018). Verder is het zo dat agrarisch natuurbeheer niet overal 'mag': alleen boeren met grond in kerngebieden komen in aanmerking voor deelname aan de subsidieregeling.

\section{Culturele normen boerengemeenschap}

De invloed van collega-boeren kan boeren aanmoedigen tot natuurinclusieve praktijken (0), maar ook ontmoedigen. Veel boeren meten hun zelfbeeld en hun gedrag af aan wat hun collega's/ buren zien als een 'goede boer' (Burton, 2004). Dit heeft een directe relatie met het landschap, omdat het landschap de zichtbare uiting is van het beheer door de boer. Burton beschrijft een casestudy van een akkerbouwgebied waar boeren de gewoonte hadden om rond te rijden om het land van hun collega's te beoordelen en daaraan hun eigen vakmanschap af te meten. Boeren hielden daar rekening mee, door hun land langs de weg extra onkruidvrij te houden en hun hagen goed te snoeien. Ook uit andere publicaties is bekend dat boeren een 'tidy landscape' beschouwen als een teken van vakmanschap en goed beheer (De Krom, 2017; Mills et al., 2016). Dit kan een drempel vormen om mee te doen met agrarisch natuurbeheer. Afkeuring door buren voor deelname aan agrarisch natuurbeheer kan ontmoedigend werken (Siebert et al., 2006). In de hoofdstukken 3-6 diepen we de rol van culturele normen verder uit. 


\section{Verschenen documenten in de reeks Technical reports van de Wettelijke Onderzoekstaken Natuur \& Milieu}

WOt-technical reports zijn beperkt verkrijgbaar bij het secretariaat van Unit Wettelijke Onderzoekstaken Natuur \& Milieu te Wageningen. T 0317 - 4854 71; E info.wnm@wur.nl

WOt-technical reports zijn ook te downloaden via de website www.wur.nl/wotnatuurenmilieu

113 Arets, E.J.M.M., J.W.H van der Kolk, G.M. Hengeveld, J.P. Lesschen, H. Kramer, P.J. Kuikman \& M.J. Schelhaas (2018). Greenhouse gas reporting for the LULUCF sector in the Netherlands. Methodological background, update 2018

114 Bos-Groenendijk, G.I. en C.A.M. van Swaay (2018). Standaard Data Formulieren Natura 2000-gebieden; Aanvullingen vanwege wijzigingen in Natura 2000-aanwijzingsbesluiten

115 Vonk, J. , S.M. van der Sluis, A. Bannink, C. van Bruggen, C.M. Groenestein, J.F.M. Huijsmans, J.W.H. van der Kolk, L.A. Lagerwerf, H.H. Luesink, S.V. Oude Voshaar \& G.L. Velthof (2018.) Methodology for estimating emissions from agriculture in the Netherlands - update 2018. Calculations of $\mathrm{CH} 4, \mathrm{NH} 3, \mathrm{~N} 2 \mathrm{O}, \mathrm{NOx}, \mathrm{PM} 10$, PM2.5 and CO2 with the National Emission Model for Agriculture (NEMA)

116 IJsseldijk, L.L., M.J.L. Kik, \& A. Gröne (2018). Postmortaal onderzoek van bruinvissen (Phocoena phocoena) uit Nederlandse wateren, 2017. Biologische gegevens, gezondheidsstatus en doodsoorzaken.

117 Mattijssen, T.J.M. \& I.J. Terluin (2018). Ecologische citizen science; een weg naar grotere maatschappelijke betrokkenheid bij de natuur?

118 Aalbers, C.B.E.M., D. A. Kamphorst \& F. Langers (2018). Bedrijfs- en burgerinitiatieven in stedelijke natuur. Hun succesfactoren en knelpunten en hoe de lokale overheid ze kan helpen slagen.

119 Bruggen, C. van, A. Bannink, C.M. Groenestein, J.F.M. Huijsmans, L.A. Lagerwerf, H.H. Luesink, S.M. van der Sluis, G.L. Velthof \& J. Vonk (2018). Emissies naar lucht uit de landbouw in 2016. Berekeningen met het model NEMA

120 Sanders, M.E., F. Langers, R.J.H.G. Henkens, J.L.M. Donders, R.I. van Dam, T.J.M. Mattijssen \& A.E. Buijs (2018). Maatschappelijke initiatieven voor natuur en biodiversiteit; Een schets van de reikwijdte en ecologische effecten en potenties van maatschappelijke initiatieven voor natuur in feiten en cijfers

121 Farjon, J.M.J., A.L. Gerritsen, J.L.M. Donders, F. Langers \& W. Nieuwenhuizen (2018). Condities voor natuurinclusief handelen. Analyse van vier praktijken van natuurinclusief ondernemen

122 Gerritsen, A.L., D.A. Kamphorst \& W. Nieuwenhuizen (2018). Instrumenten voor maat- schappelijke betrokkenheid. Overzicht en analyse van vier cases

123 Vullings, L.A.E., A.E. Buijs, J.L.M. Donders, D.A. Kamphorst, H. Kramer \& S. de Vries (2018). Monitoring van groene burgerinitiatieven; Analyse van de resultaten van een pilot en nulmeting in vier gemeenten

124 Boonstra, F.G., Th.C.P. Melman, W. Nieuwenhuizen \& A. Gerritsen (2018). Aanpak evaluatie stelselvernieuwing agrarisch natuurbeheer; Uitgangspunten en opties voor een beleidsevaluatie

125 Vullings, L.A.E., A.E. Buijs, J.L.M. Donders \& D.A. Kamphorst (2018). Monitoring van groene burgerinitiatieven; Methodiek, indicatoren en ervaring met pilot en nulmeting.

126 Beltman, W.H.J., M.M.S. ter Horst, P.I. Adriaanse \& A. de Jong (2018). Manual for FOCUS_TOXSWA v5.5.3 and for expert use of TOXSWA kernel v3.3; User's Guide version 5

127 Van der Heide, C.M. \& M.M.M. Overbeek (2018). Natuurinclusief handelen en ondernemen. Scopingstudie 'Bedrijven, economie en natuur'

128 Langers, F. (2018). Recreatie in groenblauwe gebieden; Actualisatie van CLO-indicator 1258 (Bezoek aan groenblauwe gebieden) op basis van data van het Continu Vrijetijdsonderzoek uit 2015

129 Glorius, S.T., I.Y.M. Tulp, A. Meijboom, L.J. Bolle and C. Chen (2018). Developments in benthos and fish in gullies in an area closed for human use in the Wadden Sea; 2002-2016

130 Kamphorst, D.A \& T.J.M. Mattijssen (2018). Scopingstudie Vermaatschappelijking van natuur. Een overzicht van onderzoek bij Wageningen Universiteit \& Research voor het Planbureau voor de Leefomgeving en het ministerie van Landbouw, Natuur en Voedselkwaliteit

131 Breman, B.C., T.J.M. Mattijssen \& T.M. Stevens (2018). Natuur 2.0. Het natuurdebat op social media.

132 Vries, S. de \& W. Nieuwenhuizen (2018) HappyHier: hoe gelukkig is men waar?; Gegevensverzameling en bepaling van de invloed van het type grondgebruik, deel II

133 Kistenkas, F.H., W. Nieuwenhuizen, D.A. Kamphorst \& M.E.A. Broekmeyer (2018). Natuuren landschap in de Omgevingswet.

134 Michels, R, V. Diogo, W.H.G.J. Hennen, L.F. Puister 
(2018). Instrumentarium Kosten Natuurbeleid 2018 - Status A; IKN versie 3.0

135 Sanders, M.E. (2018). Voortgang realisatie natuurnetwerk. Technische achtergronden bij de digitale Balans van de Leefomgeving 2018

136 Koffijberg K., J.S.M. Cremer, P. de Boer, J. Nienhuis, K. Oosterbeek \& J. Postma (2018). Broedsucces van kustbroedvogels in de Waddenzee in 2017

137 Egmond, F.M. van, S. van der Veeke, M. Knotters, R.L. Koomans, D. Walvoort, J. Limburg (2018). Mapping soil texture with a gamma-ray spectrometer: comparison between UAV and proximal measurements and traditional sampling; Validation study

138 Glorius, S.T., A. Meijboom, J.T. Wal van der, J.S.M. Cremer (2018). Ontwikkeling van enkele droogvallende mosselbanken in de Nederlandse Waddenzee; situatie 2017.

139 Berg, F. van den, A. Tiktak, D.W.G. van Kraalingen, J.G. Groenwold \& J.J.T.I. Boesten (2018). User manual for GeoPEARL version 4.4.4.

140 Kuiters, A.T., G.A. de Groot, D.R. Lammertsma, H.A.H. Jansman \& J. Bovenschen (2018). Genetische monitoring van de Nederlandse otterpopulatie; Ontwikkeling van populatieomvang en genetische status 2017/2018

141 Müskens G.J.D.M., M.J.J. La Haye, R.J.M. van Kats \& A.T. Kuiters (2018). Ontwikkeling van de hamsterpopulatie in Limburg. Stand van zaken voorjaar 2018

142 Glorius, S.T. (2018). Ontwikkeling van de bodemdiergemeenschap in de geulen van referentiegebied Rottum; Tussenrapportage twaalf jaar na sluiting (najaar 2017).

143 Brouwer, F., F. de Vries en D.J.J. Walvoort (2018). Basisregistratie Ondergrond (BRO); Actualisatie bodemkaart: herkartering van de bodem in Flevoland

144 Knotters, M. en F.M. van Egmond (2018). Selectie van inwinningstechnieken voor bodemdata; Selecteren vanuit de (onderzoeks)vraag

145 Stuyt, L.C.P.M., M. Knotters, D.J.J. Walvoort, F. Brouwer \& H.T.L. Massop (2018). Basisregistratie Ondergrond - Gd-kartering Laag-Nederland 2018; Provincie Flevoland

146 Arets, E.J.M.M., J.W.H van der Kolk, G.M. Hengeveld, J.P. Lesschen, H. Kramer, P.J. Kuikman \& M.J. Schelhaas (2019). Greenhouse gas reporting of the LULUCF sector in the Netherlands. Methodological background, update 2019

147 Bruggen, C. van, A. Bannink, C.M. Groenestein, J.F.M. Huijsmans, L.A. Lagerwerf, H.H. Luesink, S.M. van der Sluis, G.L. Velthof \& J. Vonk (2019). Emissies naar lucht uit de landbouw in 2017.
Berekeningen met het model NEMA.

148 Lagerwerf, L.A., A. Bannink, C. van Bruggen, C.M. Groenestein, J.F.M. Huijsmans, J.W.H. van der Kolk, H.H. Luesink, S.M. van der Sluis, G.L. Velthof \& J. Vonk (2019). Methodology for estimating emissions from agriculture in the Netherlands. Calculations of $\mathrm{CH}_{4}, \mathrm{NH}_{3}, \mathrm{~N}_{2} \mathrm{O}, \mathrm{NO}_{x}$, NMVOC, PM10, PM2.5 and $\mathrm{CO}_{2}$ with the National Emission Model for Agriculture (NEMA) - update 2019.

149 Bakker, G., M. Heinen, H.P.A. Gooren, W.J.M. de Groot, F.B.T. Assinck \& E.W.J. Hummelink (2019). Hydrofysische gegevens van de bodem in de Basisregistratie Ondergrond (BRO) en het Bodemkundig Informatie Systeem (BIS); Update 2018.

150 IJsseldijk, L.L., M.J.L. Kik, \& A. Gröne (2019). Postmortaal onderzoek van bruinvissen (Phocoena phocoena) uit Nederlandse wateren, 2018. Biologische gegevens, gezondheidsstatus en doodsoorzaken.

151 Daamen, W.P., A.P.P.M. Clerkx \& M.J. Schelhaas (2019). Veldinstructie Zevende Nederlandse Bosinventarisatie (2017-2021); Versie 2.0.

152 Bikker, P., L.B. Šebek, C. van Bruggen \& O. Oenema (2019). Stikstof- en fosfaatexcretie van gangbaar en biologisch gehouden landbouwhuisdieren. Herziening excretieforfaits Meststoffenwet 2019.

153 Berg, F. van den, H. Baveco \& E.L. Wipfler (2019). User manual for SAFE (Select Application date For Evaluation) to support the use of the GEM scenarios for cultivations in glasshouses; Version 1.1

154 Os, J. van, L.J.J. Jeurissen en H.H. Ellen (2019). Rekenregels pluimvee voor de Landbouwtelling; Verantwoording van het gebruik van het Identificatie- \& Registratiesysteem.

155 Brouwer, F. \& D.J.J. Walvoort (2019). Basisregistratie Ondergrond (BRO) - Actualisatie bodemkaart; Herkartering van de veengebieden in Eemland

156 Sanders, M.E., R.J.H.G. Henkens \& D.M.E. Slijkerman (2019). Convention on Biological Diversity; Sixth National Report of the Kingdom of the Netherlands.

157 Kuiters, A.T., G.A. de Groot, D.R. Lammertsma, H.A.H. Jansman, J. Bovenschen, M.C. Boerwinkel \& M. Laar (2019). Genetische monitoring van de Nederlandse otterpopulatie; Ontwikkeling van populatieomvang en genetische status 2018/2019.

158 Sanders, M.E. \& H.A.M. Meeuwsen (2019). Basisbestand Natuur en Landschap

159 Visser, T., H.A.M Meeuwsen \& Th.C.P. Melman 
(2019). MNP-(Model for Nature Policy) Agrarisch; Uitwerking voor scenario's uit de Natuurverkenning 2020.

160 Jong, A. de, A. Poot \& P.I. Adriaanse (2019). Impact analysis for the purpose of the introduction of DROPLET version 1.3.2.

161 Westerink, J., T.A. de Boer, M. Pleijte \& R.A.M. Schrijver (2019). Kan een goede boer natuurinclusief zijn?; De rol van culturele normen in een beweging richting natuurinclusieve landbouw.

165 Glorius, S.T., A. Meijboom, J. Schop \& J.T. van der Wal (2019). Ontwikkeling van enkele droogvallende mosselbanken in de Nederlandse Waddenzee; situatie 2018.

166 Pedroli, B, During, R. (2019). De paradox van een maakbare natuur - ingebakken en omstreden; Betekenis culturele identiteit voor draagvlak natuurbeleid en -beheer.

Dit Technical report is gemaakt conform het Kwaliteitsmanagementsysteem (KMS) van de unit Wettelijke Onderzoekstaken Natuur \& Milieu, onderdeel van Wageningen University \& Research.

De WOT Natuur \& Milieu voert wettelijke onderzoekstaken uit op het beleidsterrein natuur en milieu. Deze taken worden uitgevoerd om een wettelijke verantwoordelijkheid van de Minister van Landbouw, Natuur en Voedselkwaliteit (LNV) te ondersteunen. We zorgen voor rapportages en data voor (inter)nationale verplichtingen op het gebied van agromilieu, biodiversiteit en bodeminformatie, en werken mee aan producten van het Planbureau voor de Leefomgeving zoals de Balans van de Leefomgeving.

\section{Disclaimer wot-publicaties}

De reeks 'WOt-technical reports' bevat onderzoeksresultaten van projecten die kennisorganisaties voor de unit Wettelijke Onderzoekstaken Natuur \& Milieu hebben uitgevoerd.

Dit onderzoek is uitgevoerd in opdracht van het Planbureau voor de Leefomgeving (PBL). Het PBL is een inhoudelijk onafhankelijk onderzoeksinstituut op het gebied van milieu, natuur en ruimte, zoals gewaarborgd in de Aanwijzingen voor de Planbureaus, Staatscourant 3200, 21 februari 2012.

Dit onderzoeksrapport draagt bij aan de kennis die verwerkt wordt in meer beleidsgerichte publicaties zoals Natuurverkenning, Balans van de Leefomgeving en andere thematische verkenningen.

Het onderzoek is gefinancierd door het ministerie van Landbouw, Natuur en Voedselkwaliteit (LNV). 


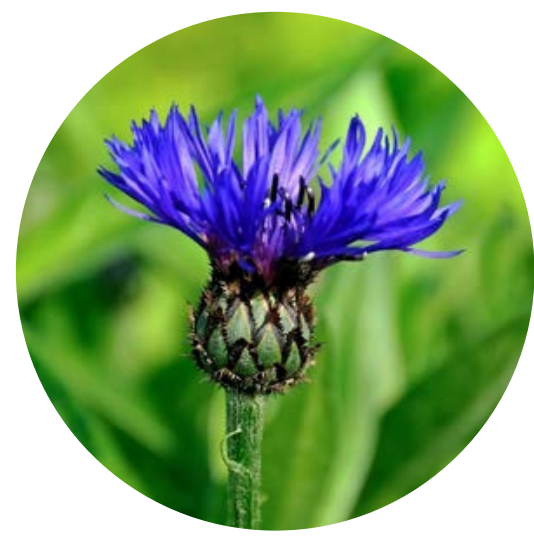

Thema Periodieke

Evaluatie Natuurbeleid

Wettelijke Onderzoekstaken Natuur \& Milieu

P.O. Box 47

6700 AA Wageningen

T (0317) 485471

E info.wnm@wur.nl

ISSN 2352-2739

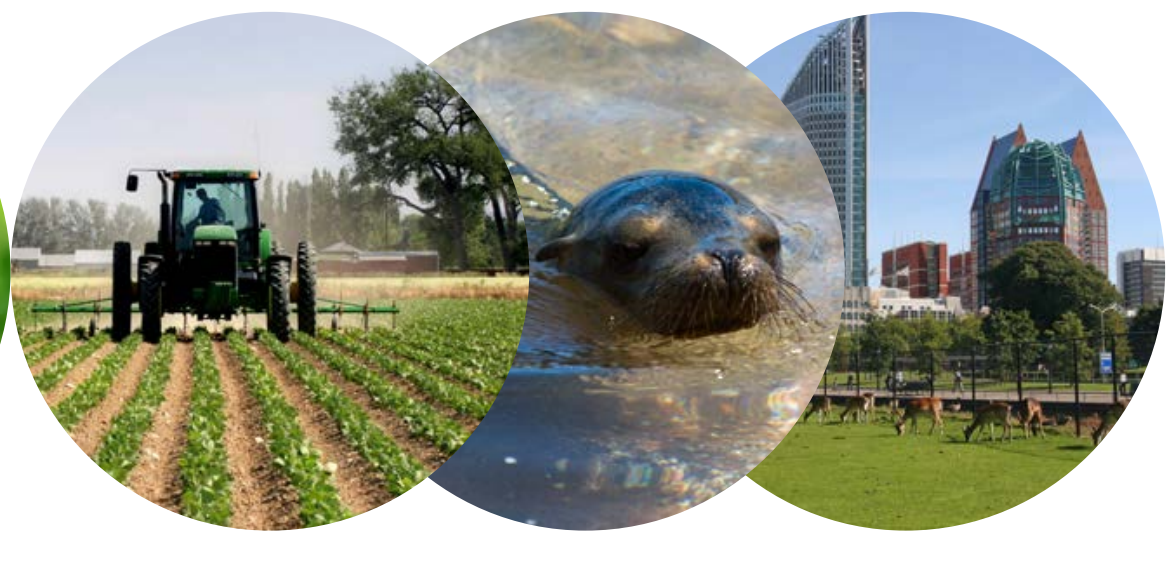

De missie van Wageningen University \& Research is 'To explore the potential of nature to improve the quality of life'. Binnen Wageningen University \& Research bundelen 9 gespecialiseerde onderzoeksinstituten van Stichting Wageningen Research en Wageningen University hun krachten om bij te dragen aan de oplossing van belangrijke vragen in het domein van gezonde voeding en leefomgeving. Met ongeveer 30 vestigingen, 5.000 medewerkers en 10.000 studenten behoort Wageningen University \& Research wereldwijd tot de aansprekende kennisinstellingen binnen haar domein. De integrale benadering van de vraagstukken en de samenwerking tussen verschillende disciplines vormen het hart van de unieke Wageningen aanpak. 